Florida International University FIU Digital Commons

8-1979

\title{
A limnological description of Lake Marco Shores, a manmade brackish water lake
}

Charles M. Courtney

Florida International University

DOI: $10.25148 /$ etd.FI14061530

Follow this and additional works at: https://digitalcommons.fiu.edu/etd

Part of the Environmental Studies Commons

\section{Recommended Citation}

Courtney, Charles M., "A limnological description of Lake Marco Shores, a manmade brackish water lake" (1979). FIU Electronic Theses and Dissertations. 2658.

https://digitalcommons.fiu.edu/etd/2658

This work is brought to you for free and open access by the University Graduate School at FIU Digital Commons. It has been accepted for inclusion in FIU Electronic Theses and Dissertations by an authorized administrator of FIU Digital Commons. For more information, please contact dcc@fiu.edu. 
To Professors Patsy McLaughlin, Walter Goldberg and Robert Judge

This thesis, having been approved in respect to form and mechanical execution, is referred to you for judgment upon its substantial merit.

Dean Jack L. Clark

School of Technology

The thesis of Charles M. Courtney is approved.

Professor

Professor

Professor

Major Professor

Date of Examination: 
A IIMNOLOGICAL DESCRIPTION OF LAKE MARCO SHORES -

A MANMADE, BRACKISH WATER LAKE

by

Charles M. Courtney

A thesis submitted in partial fulfillment of the requirements for the degree of MASTER OF SCIENCE

in

ENVIRONMENTAL AND URBAN SYSTEMS

at

FLORIDA INTERNATIONAL UNIVERSITY

Committee in charge:

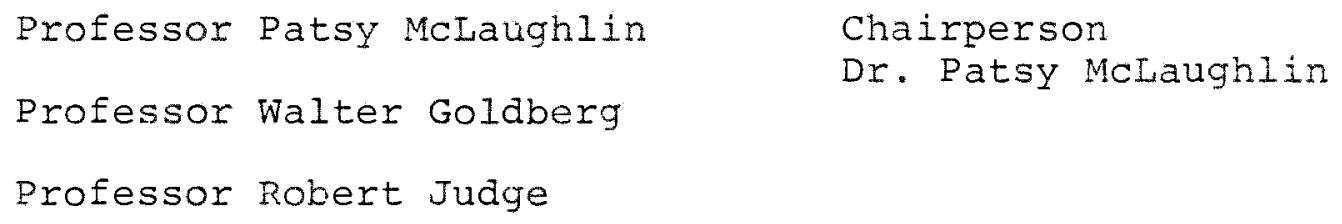


A LIMNOLOGICAL DESCRIPTION OF LAKE MARCO SHORES -

A MANMADE, BRACKISH WATER LAKE

by

Charles M. Courtney

A thesis submitted in partial fulfillment of the requirements for the degree of

MASTER OF SCIENCE

in

ENVIRONMENTAL AND URBAN SYSTEMS

at

FLORIDA INTERNATIONAL UNIVERSITY

1979 
As the scope of this study developed, I relied increasingly on the assistance of others. My major professor, Dr. Patsy McLaughlin, encouraged and assisted me throughout the research and in the final review of this manuscript. The other members of my committee, Dr. Walter Goldberg, Dr. Robert Judge, and Dr. Daniel Jackson, a former committee member who left the University, offered positive advice and constructive criticism.

I am also indebted to Mr. Paul Larsen (Larsen and Associates), Drs. James Carpenter and Bernard Yokel (Rosenstiel School of Marine and Atmospheric Sciences University of Miami), Dr. Jon Moulding (U.S. Army Corps of Engineers), and Delbert Hicks (U.S. Environmental Protection Agency) for their helpful comments and data sharing. Field assistance during various phases of sample collection was frequently required, and I owe many thanks to the staff of the Marco Applied Marine Ecology station (MAMES), particularly Messrs. James Gallagher, Gregory Ballinger, Douglas Finan and Paul Genoa. Chemical analytical assistance was kindly provided by Mr. James Hatcher and Dr. Douglas Armstrong (MAMES). Dr. James Charlesworth (University of Toledo) performed the $\mathrm{X}$-ray defraction analysis of sediments. Ms. Sharon Frusheli spent many hours typing this manuscript and Mr. James Epaves proved very helpful in figure preparation. Lastly, I would like to thank my wife, Alfdis, and my 
chilaren, Steinunn, Kristine, and Sarah for their patience during my many days of absence and for their continued support and encouragement.

This research was financially supported by The Deltona Corporation. 


\section{TABLE OF CONTENTS}

ACKNOWLEDGEMENTS $\ldots \ldots \ldots \ldots \ldots \ldots \ldots \ldots \ldots \ldots \ldots$

PAGE

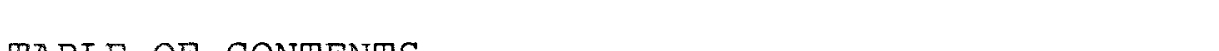

TABLE OF CONTENTS $\ldots \ldots \ldots \ldots \ldots \ldots \ldots \ldots \ldots \ldots$

iv

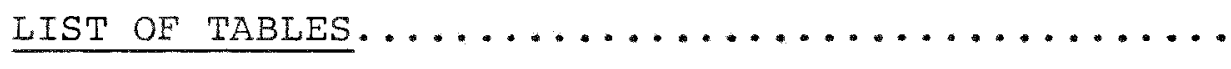

$v \dot{i}$

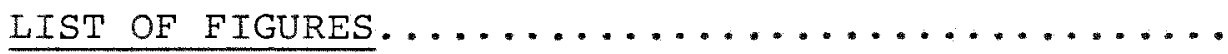

ix

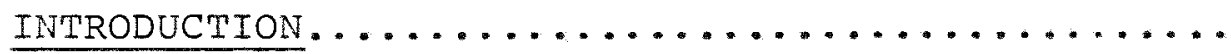

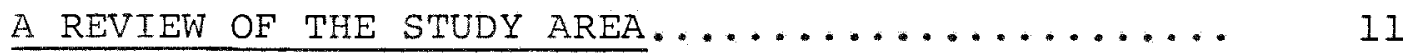

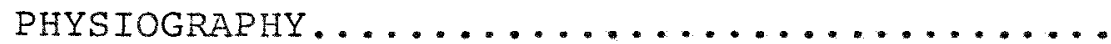

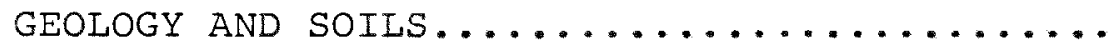

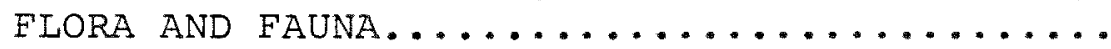

PHYSICOCHEMICAL STUDIES OF LAKE MARCO

SHORES AND ITS IMMEDIATE SURROUNDINGS.......

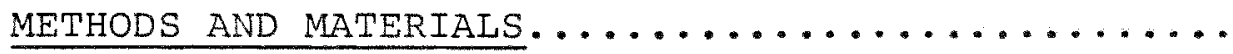

PHYSICAL PARAMETERS.................

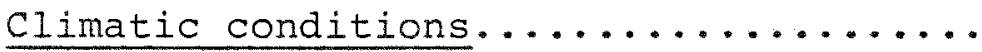

Lake sediments.....................

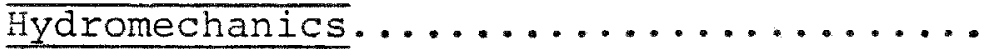

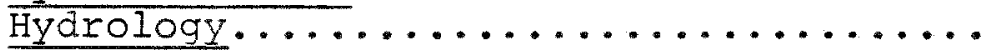

Optical and thermal properties..........

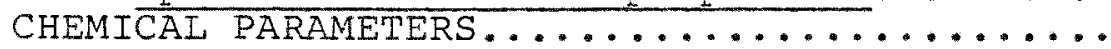

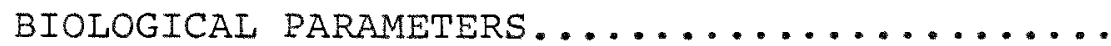

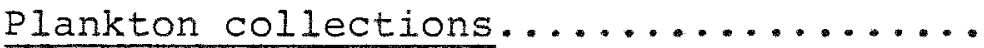

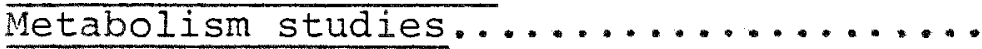

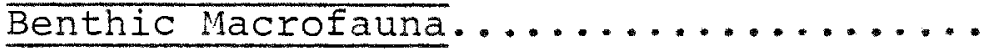

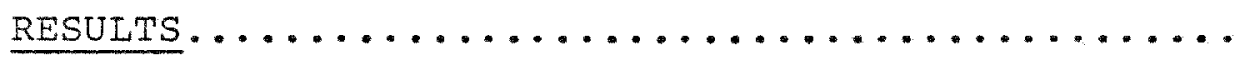

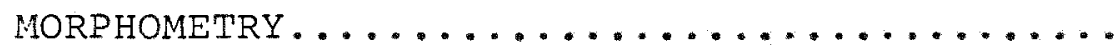

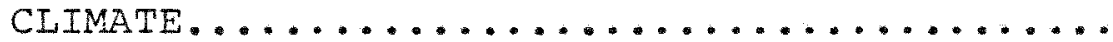

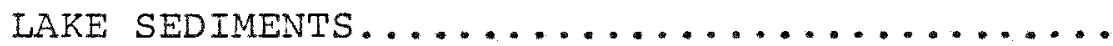

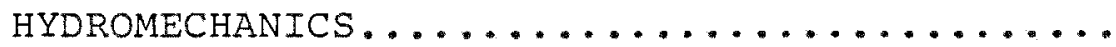

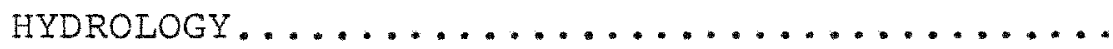

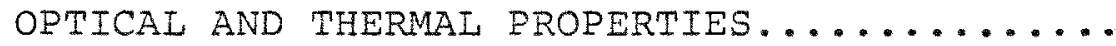

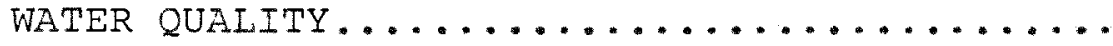




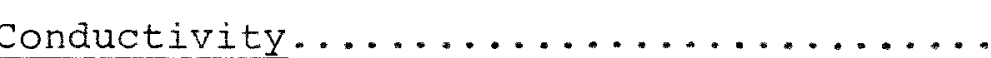

PAGE

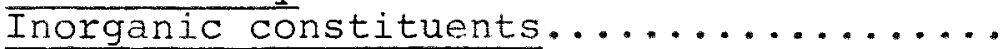

94

97

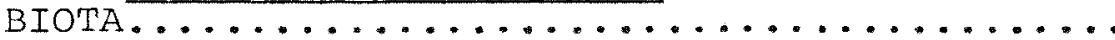

104

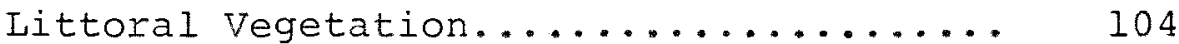

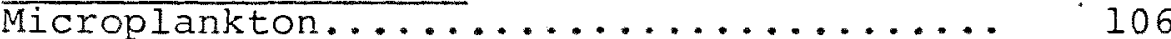

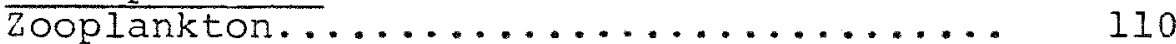

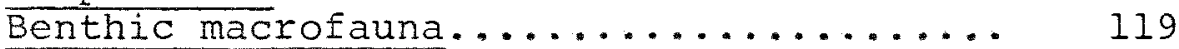

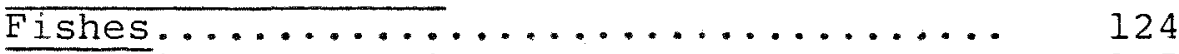

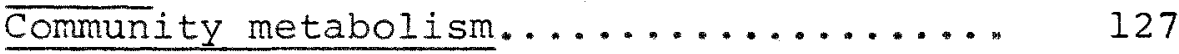

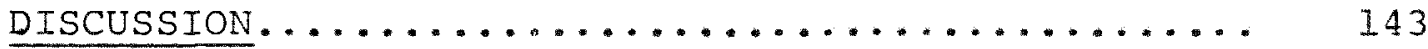

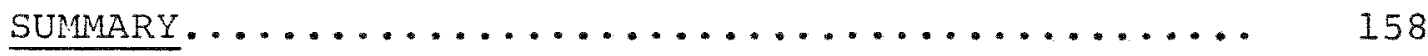

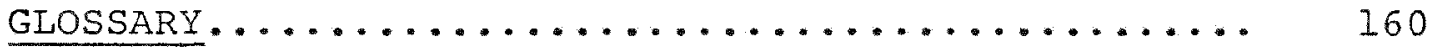

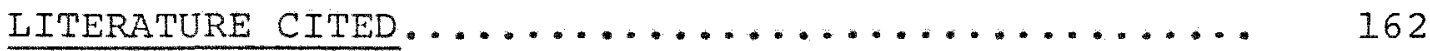




\section{LIST OF TABLES}

Table

$\underline{\text { Page }}$

1. Ash free dry weight determinations of standing crop biomass for four non-woody plant associations in the watershed of Lake Marco Shores.

2. A summary of profile means $(n=6)$ of temperature and dissolved oxygen collected on 15 December, 1972 at the west end of Lake Marco Shores.

3. Averaged water quality parameters for the surface 21 $(0.15 \mathrm{~m})$ and bottom $(9.15 \mathrm{~m})$ at the west end of Lake Marco Shores for the period September, 1974 to January, 1975 .

4. A 9 January, 1977 profile of water quality at station WQ4 in Lake Marco Shores.

5. Morphometric data for Lake Marco Shores.

6. Averaged monthly values for selected ground water 73 parameters.

7. Ground water seepage rate and chemical quality at 75 Lake Marco Shores. 
Table

Page

8. Ground water seepage rate and chemical quality from the Lake Marco Shores drainage area.

9. The water quality of three rainfall events at Marco Island, Florida.

10. The vertical distribution of selected inorganic constituents at Lake Marco Shores.

11. The vertical distribution of chloride, color, and turbidity at Lake Marco shores on selected dates in 1978 .

12. A standing crop determination for Ruppia mari- 105 tima at Lake Marco Shores - 14 March, 1978.

13. A list of microplankton species collected at 108 Lake Marco Shores for the period January December, 1978.

14. Zooplankton species collected at Lake Marco Shores for period January - December, 1978. 
Table

$\underline{\text { Page }}$

15. A qualitative comparison of crustaceans from

Lake Marco Shores, the SR 951 canal, and the lake watershed.

16. The results of bimonthly benthic sampling at Lake Marco Shores for the period February December, 1978 .

17. Merristic data* for the fishes collected from Lake Marco Shores during the period 16-17 May, 1979. *Extracted from Finan (1979).

18. The results of light and dark bottles productivity measurements at Lake Marco Shores for 1978.

19. The results of a vertical profile of periphyton 137 measurements in Lake Marco Shores.

20. A comparison of selected water quality parameters 147 in Lake Marco Shores with the Marco estuary and other lakes in Collier County. 


\section{LIST OF EIGURES}

Figure

Page

1. A site map showing Lake Marco Shores and its drainage basin in relation to the Marco Island estuarine ecosystem.

2. A map of Lake Marco shores showing the location of benthic macroinvertebrate, water quality, and ground water seepage sampling stations.

3. Surface $(0.15 \mathrm{~m})$ and bottom $(9.14 \mathrm{~m})$ salinity, dissolved oxygen, pH, temperature and rainfall measurements at Lake Marco Shores for the period April, 1974 - January, 1975.

4. Temperature profiles at Lake Marco Shores for the period October, 1976 to June, 1977.

5. Conductivity profiles at Lake Marco Shores for the period october, 1976 to June, 1977.

6. Salinity profiles at Lake Marco Shores for the period October, 1976 to June, 1977.

7. Dissolved oxygen profiles at Lake Marco Shores for the period October, 1976 to June, 1977. 


\section{LIST OF FIGURES CONTINUED}

Fiqure

Page

8. A specially designed submersible pump used for collecting samples of water and plankton in vertical profile while allowing for the simultaneous measurement of in situ temperature and dissolved oxygen.

9. Regression of total monthly discharge* at the SR 951 culverts on monthly rainfall as recorded at Rookery Bay. *Adapted from Daddio and Van de Kreeke (1979).

10. A flume* used to measure benthic metabolism at Lake Marco Shores. *Designed by Carpenter (1973).

11. A species - area curve used to determine the number of cores necessary to adequately sample 90 percent of the benthic species present.

12. A bathymetric map of Lake Marco Shores.

13. A summary of meteorological data for 1978 at the study site. 
Figure

Page

14. A summary of monthly rainfall for 1978 at two 63 sites bracketing Lake Marco Shores and at 3 wedge gage stations in the lake drainage basin.

15. Mean monthly rainfall for the period 1973 - 1977.

16. A comparison of the tidal record at MacIlvane 69 Bay and Lake Marco Shores watershed for the month of January, 1978.

17. Water level hydrographs and the mean rainfall 70 record for 1978 at sites in the Lake Marco Shores watershed.

18. Relationships of water elevation and chloride concentration between well sites $1,2,3,4$ and 5 .

19. Monthly secchi depth, chlorophyll a and phaeophy80 tin measurements at Lake Marco Shores for 1978.

20. Temperature profiles at station WQ4 for the period January - June, 1978. 


\section{LIST OF FIGURES CONTINUED}

Figure

Page

21. Temperature profiles at station wQ4 for the period July - December, 1978.

22. Results of a 24 hour continuous profile of lake water temperatures during the period 1921 January, 1977.

23. Dissolved oxygen profiles at station WQ4 for the period January - June, 1978.

24. Dissolved oxygen profiles at station WQ4 for the period July - December, 1978.

25. A profile of hydrogen ion concentrations at Lake Marco Shores.

26. Monthly $\mathrm{TPO}_{4}, \mathrm{OPO}_{4}$, and TKN measurements at Lake Marco Shores for 1978.

27. A profile of total organic carbon at Lake Marco Shores.

28. Conductivity profiles at station WQ4 for the period January - June, 1978. 
Figure

$\underline{\text { Page }}$

29. Conductivity profiles at station WQ4 for the 96 period July - December, 1978.

30. Salinity profiles at station WQ4 for the period 100 January - June, 1978.

31. Salinity profiles at station WQ4 for the period 101 July - December, 1978.

32. MonthIy $\mathrm{NH}_{3}-\mathrm{N}, \mathrm{NO}_{3}-\mathrm{N}$, and $\mathrm{NO}_{2}-\mathrm{N}$ measurements at 103 Lake Marco Shores for 1978.

33. A summary of the monthly vertical distribution of 107 microplankton taxa at Lake Marco Shores for 1978.

34. The monthly relative distribution of Microcyclops 112 sp. from the three main strata of Lake Marco Shores for 1978 .

35. The noon vs. midnight distribution of Branchionus 113 urceolaris and Microcyclops sp. in quarterly samples from the mixolimnion (MI), chemocline (CH) and monimolimnion (MO) at Lake Marco Shores. 


\section{LIST OF FIGURES CONTINUED}

Eigure

Page

36. Monthly variations in the relative abundance of three Microcyclops life stages for 1978.

37. The monthly relative distribution of Branchionus urceolaris in the three main strata of Lake Marco Shores for 1978.

38. The monthly abundance of Nothalca in 1978 .

39. The monthly relative distribution of an uniden118 tified vileger larva in the three main strata of Lake Marco Shores of 1978.

40. Species diversity* for the total benthic community at Lake Marco Shores for 1978. * Shannon and Weaver (1949).

41. Community metabolism* in the water column at station A8 in the lake's drainage basin. *Extracted from USEPA data.

42. Community metabolism* in the water column at station A24 in the lake's drainage basin. *Extracted from USEPA data. 


\section{LIST OF FIGURES CONTINUED}

Figure

Page

43. Community metabolism* in the water column at 130 station B South in the lake's drainage basin. *Extracted from USEPA data.

44. Community metabolism* in the water column at station B North in the lake's drainage basin. *Extracted from USEPA data.

45. Community metabolism in the water column at Chara pond in the lake's drainage basin.

46. Community metabolism in the water column at Lake Marco Shores based on an integration to the $1.52 \mathrm{~m}$ depth for the period 31 January - 1 February, 1978.

47. Community metabolism in the water column at Lake 135 Marco Shores based on an integration to the $2.74 \mathrm{~m}$ depth.

48. The diurnal production of oxygen at selected depths in Lake Marco Shores on 31 January, 1978.

49. Community metabolism in the water column at Lake 139 Marco Shores for the period 4-5 April, 1978. 
Eigure

Page

50. Community metabolism in the water column at lake 140 Marco Shores for the period 31 May - 1 June, 1978.

51. Community metabolism in the water column at Lake 141 Marco Shores for the period 29-30 August, 1978. 


\section{INTRODUCTION}

The state of Florida is dotted by hundreds of fresh water lakes, but from central Florida to the southern tip of the penninsula, shallow water ponds and marshes predominate. These ecotypes are especially typical of southwest Florida where they are said to mediate the flow of fresh water to the mangrove dominated estuarine system (Carter et al. 1973). The Marco Island estuary is one of the northenmost estuaries within this system, and its physicochemical and biological characteristics have been described by weinstein et al. (1977).

The lakes that do exist in southwest Florida are for the most part of two types, either sinkhole or man-made. Five sinkhole lakes exist west of the Everglades and only one, Deep Lake, is located within Collier County (Parker and Cooke, 1944). Of the four remaining sinkhole lakes, Little Salt Spring in Sarasota County has received the most recent attention, but that was chiefly because of its unique archeological value (Clausen et al., 1979). Deep Lake has been studied extensively by Hunt (1958) and Schneider (1973). Schneider's (1973) finding indicated that Deep Lake was thermally classified as warm monomictic because when circulation did occur, it occurred during the winter.

While sinkhole lakes are infrequent in southwest Florida, manmade lakes have proliferated in recent years. collier county has experienced a substantial increase in 
population, and during the period 1960-1970 was ranked as one of the fastest growing counties in the United States. The lure of waterfront living in a subtropical climate was anong the factors that led to a 132 percent increase in the county's population during that period (Carter et al. 1973). New coastal developnents like Isles of Capri and Marco Island which were developed substantially in the intertidal zone received much of this new growth. Marco Island's population increased from 100 to over 1,00 during that ten year period (Paul Larsen - personal communication).

The jurisdiction of regulatory agencies such as the U.S. Army Corps of Engineers (USACE), the U.S. Environmental Protection Agency (USEPA), and the state of Florida Department of Environmental Regulation (DER) also enlarged in the early part of the 1970's. Between 1964 and 1970, 1,715 hectares of land (within this jurisdiction by today's standard's) was developed at the Marco development, and no requests for permits were denied.

As the general role of mangroves in the southwest Florida ecosystem becarne more apparent (e.g. Heald, 1971; Odum, 1971; Miller, 1974; Fell et al. 1974; Kinball and Teas, 1974; Lugo and Sneadaker, 1974; Pool et al. 1974; and Hicks and Burns, 1974) so did the public pressure on land developers to withdraw their interest from developing their intertidal ownership. Consequently, although from 1970 to the present, requests for the development of 1,322 hectares were made to 1ocal, state, and federal regulatory 
agencies, only 518 hectares were permitted for development.

The net effect of regulation has been to substantially reduce the rate of intertidal development and to divert development pressures away from the estuary and toward the uplands. There is a gentle net seaward slope of the land from Lake Okeechobee to Florida Bay of about $3 \mathrm{~cm} / \mathrm{km}$ (Carter et al. 1973) with further slope reductions in the more coastal areas. In areas of low elevation fill is required to elevate house pads and roadways. In these low areas developers have, therefore, frequently excavated lakes not only as sources of fill, but also for stormwater retention. Over 100 excavations ranging in size from several hundred square meters to over 40 hectares are presently inventoried in Collier county, and concerns over their relationship to water quantity and quality have been expressed by the collier County Water Management Board and the Big Cypress Basin Board of the South Florida Water Management District (Reynolds et al. 1979).

Lake Marco Shores was created as a aredge and dragline excavation in 1972 when The Deltona Corporation developed the Marco Shores Golf Course, inland of the tidal mangrove forests which dominate the area (Eigures 1 and 2). Much interest has been expressed in this lake because of its use as a prototype of excavations that could become prevalent in the coastal transition zone - that area between the uplands and the tidal portions of the estuary. The Deltona Corporation lis in fact proposed the development of 324 hectares of 


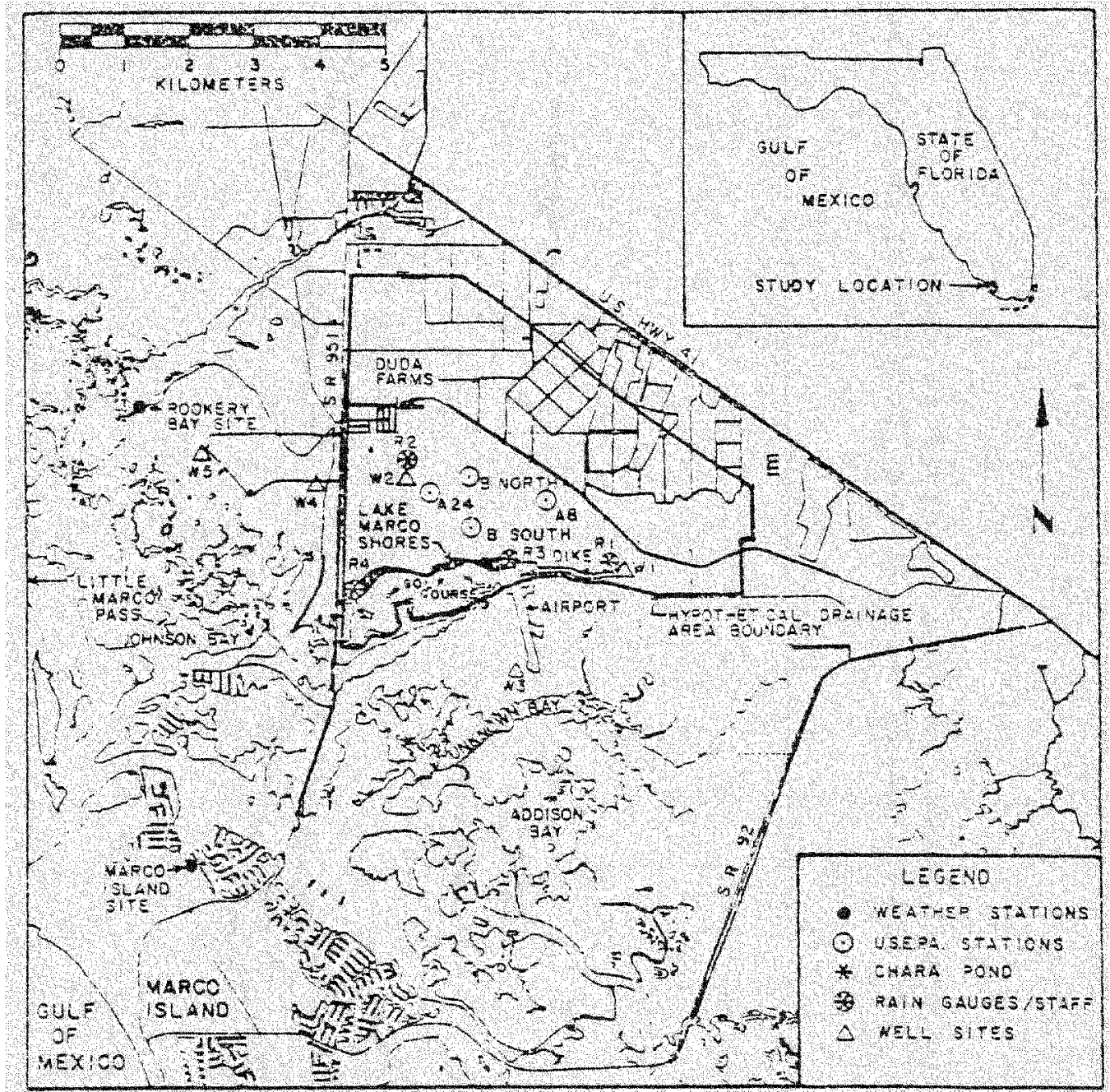

Fig. 1. A site map showing Lake llarco shores .nd its drainage basin in relation to the iarco Island estuaring ecosystem. 


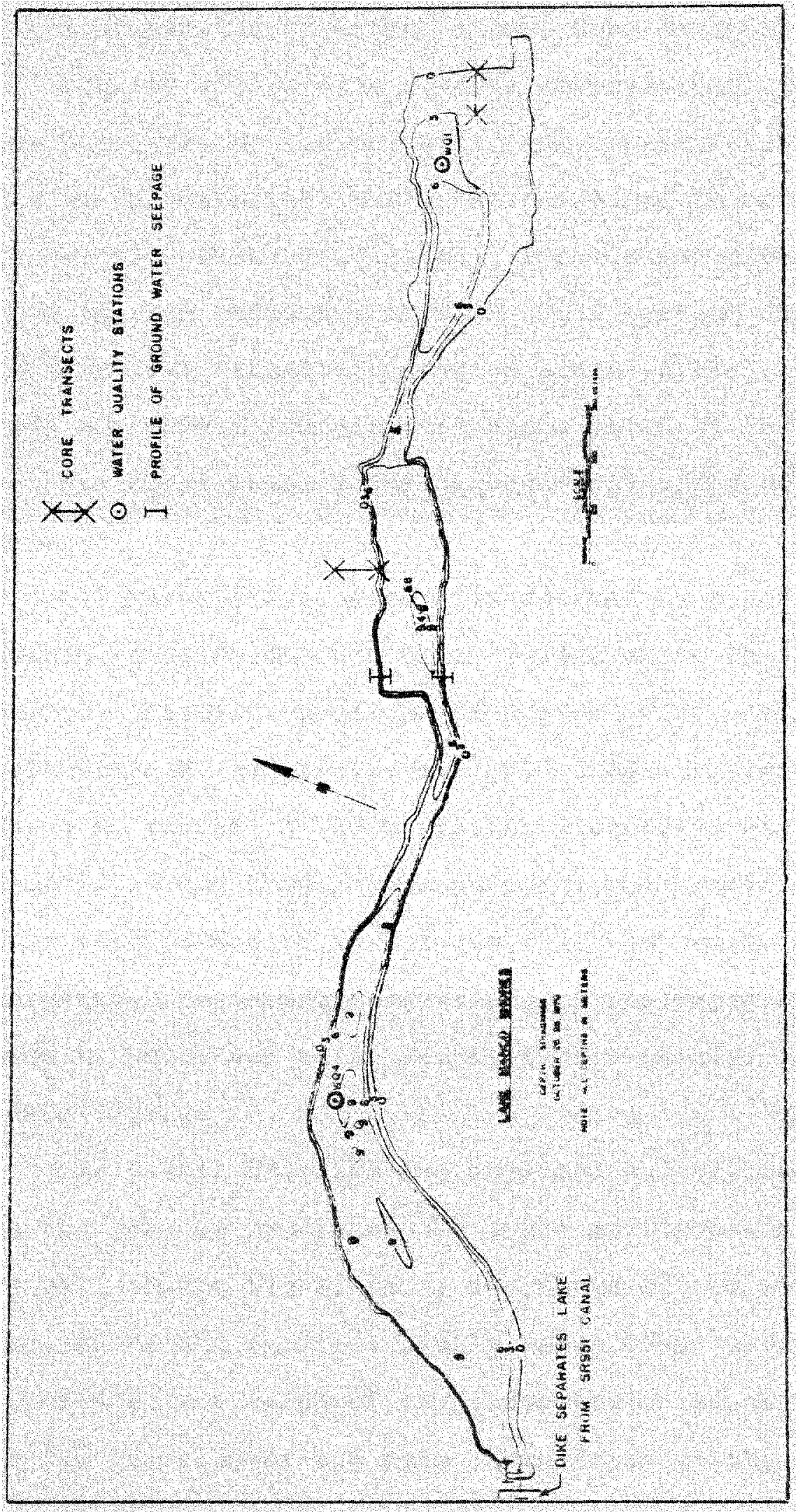

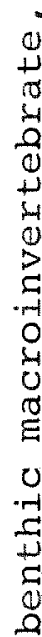

4H

동ำ

$\rightarrow+$

西

0

त्

兘宫

임

30

용

$\begin{array}{ll}n & 0 \\ 0 & \cup\end{array}$

虫

क

$\circ 3$

㟧

齐

듬

4

它

4 。ำ

- 5

$N$

-

$\therefore 3$ 
lakes of similar structure around Lake Marco Shores. During 1976 I made several observational trips to the lake, and on the basis of those observations and other historical data Lake Marco Shores seemed to be in the meromictic category of lakes. Because relatively few lakes were in this category, my main goals were to determine if the lake was meromictic over an annual cycle and to provide a complete limnological description of the lake. To achieve these goals I followed several lines of investigation:

1) Meromixis is generally defined by a perrennially stable water column which is divided among three distinct strata. Vertical profiles of conductivity, salinity, temperature and oxygen were measured frequently over an annual cycle to recognize these strata. Meromixis would be indicated if the temperature-salinity relationships were such that mixing could not occur as the result of density currents. Permanent stagnation, as indicated by permanent anoxia, would also be indicative of a stable, isolated lower layer.

2) I will describe the physical and biological setting of the lake by examining the shape and location of the lake as well as the flora, fauna and soils of the watershed that drained to the lake. A highly dense lower layer will be related to the depth of cryptodepression of the lake and to the location of the lake in relation to the estuary. 
3) The quality of the surrounding ground water was compared to that of the lake to determine if it could contribute to the vertical physicochemical makeup (and stability) that was observed in the lake. The possibility of this contribution would be verified if the vertical distribution of nutrient concentrations and selected inorganic constituents in the ground water around the lake were relatively the same as those observed at comparable depths in the lake.

4) To document a linkage of ground and lake water, experiments were designed to test the rate of seepage of water to and from the lake. The direction and quantity of seepage as well as the "quality" of the moving water were used to determine if the meromictic condition in the lake was supported by flows from these external "pools". Magnesium to chloride ratios were used to determine the origin of the hypersaline condition. Ratios similar to those of seawater would indicate that seawater was somehow concentrated.

5) The relative distribution of nutrients among the three lake strata was used to determine if the lower layer was acting as a nutrient trap. Consistently high concentrations in the lower layer relative to the surface would provide additional evidence of a meromictic condition. If such a condition existed the productivity in the upper layer will be directly compared to that of the other two layers by measuring, chlorophyll a, total organic carbon and peri- 
phyton growth and indirectly by measuring the vertical distribution of phytoplankton. If the lower layer were trapping nutrients and if the lake were stable, consistently low levels of production would occur in the upper strata, but high chlorophyll a, carbon and periphyton would occur at the interface between the top and bottom layers provided it was in the photic zone.

6) To determine the impact of forces which could breakdown the the meromictic condition, I continuously monitored climatic parameters. Continuous air temperatures were monitored and compared to changes in the vertical temperature structure of the lake to determine if natural temperature depressions could induce turnover. No continuous rainfall recording devices were present at the lake and, given the general variability of rainfall, a series of wedge gages were installed in and around the lake to determine which of two nearby continuous recorders best simulated conditions at the lake. Once this was done, data from that gage were used in conjunction with water level recorders to determine the extent of surface water continuity in the drainage basin and to evaluate the impact of rainfall quantities on the relative depths of the three lake strata. If suitable quantities of rainfall were not available to maintain the relative positions of the strata, a breakdown of the meromictic state would be evidenced by increased salinity in the uppermost strata. Conversely, a similar break- 
down might occur if the lake were able to retain all of the rain that fell on it and its drainage basin. In the latter case a breakdown would be indicated by a freshening of the lower strata.

Wind speed and direction were measured to determine the frequency, duration and intensity of wind events in relation to the longest fetch distances at the lake. Again, the salinity of the upper layer was compared to the duration of winds along these axes. The degree to which this wind duration correlated with increasing salinity of the upper layer was used to provide evidence of the degree of wind induced mixing that occurred. Theoretical and actual wave heights were compared to determine if additional factors relating to the physiography of the lake contributed to or detracted from the mixing effects of the wind.

7) No information is available concerning the biota of a coastal meromictic lake. Vertical segregation among the three strata was hypothesized for the zooplankton and littoral macrobenthos because of the strong physicochemical limiting conditions which were exhibited vertically in the lake. The numbers of individuals of the various species were observed through an annual cycle to determine if such segregation existed. High counts would indicate that a species found the conditions of a particular strata most suitable to the maintenance of its population. The shannon-Weaver index of diversity was used to describe seasonal changes in the relative numbers of species and individuals 
in the benthic community. Low diversity would indicate that the overall community was being stressed.

8) Overall community metabolism was measured to determine if some of the overall production in the lake was allochthonous or if it was all autochthonous. External production would be indicated in cases where respiration exceeded gross community production. The production and respiration attributable to the plankton were determined by light and dark bottle measurements. Attempts were also made to determine the amount of respiration that was attributable to the benthic community.

The terminology of Hutchinson (1975a, 1975b) will be used throughout the thesis and a glossary has been included to aid the reader. In the next section I will review the historical and current literature with regard to the physiography, geology and soils, flora and fauna, and chemistry of Lake Marco Shores and its immediate surroundings. 


\section{A REVIEW OF THE STUDY AREA}

PHYSIOGRAPHY

Lake Marco Shores lies within Collier County's 16,600 hectare Water Managenent District 6 at approximately $26^{\circ} 00^{\prime}$ North Latitude and $81^{\circ} 41^{\prime}$ West Longitude (Figure 1). The district is bounded by state Road 858 on the north, by the City of Naples and the Gulf of Mexico on the west, by a line from Little Marco Pass through Johnson Bay on the south, and on the east by a line one mile to the east of and parallel to State Road 951 (SR 951) (Black et al. 1973).

The lake and its immediate watershed are further bounded by a well defined series of physiographic relief features which include: the Marco Shores Golf Course, airport and dike network (average elevation $+2.13 \mathrm{~m}$ National Geodetic Vertical Datum (NGVD) to the south; the Belle Meade Grade (Royal Palm Hammock Road) to the north (mean elevation is $22.4 \mathrm{~m} \mathrm{NGVD);} \mathrm{SR} 951$ (elevation $\sim 1.8 \mathrm{~m}$ NGVD) to the west; and, the projected intersection of the Grade and the Marco Shores airport dike to the east (Figure 1). Much of the fill that was excavated for the construction of the golf course and airport came from the lake. Within this physiographic boundary the average ground elevation is $\sim 1.7 \mathrm{~m}$ NGVD, but there is a slight upward slope from the northern edge of the lake to the Belle Meade Grade.

Using Hutchinson's (1975a) lake classification system, Lake Marco Shores would be classified as an artificial depression lake. It has a general rectangular and elongate 
morphology, and it is divided along its length into three main basins each connected to the other by a relatively narrow ( $35 \mathrm{~m}$ ) channel. No islands occur in the lake. 


\section{GEOLOGY AND SOILS}

The lake was constructed in an area underlaid by strata ranging in age from the Miocene to the Recent. Limestone of the Anastasia formation approaches the surface in many areas (Klein, 1954) with Recent soils of the Argell, Pompano, Charlotte and Immokalee Find Sand series predominating to the north of the lake along with some Ochopee marl (Leighty, 1954). Tabb et al. (1977) in reviewing Leighty's classifications, however, found some errors in the watershed area between Lake Marco Shores and the Belle Meade Grade. In the light of more recent auger, wash boring, and vegetational analyses they have redescribed the soils of this area to include mangrove peat, and they have realigned many of Leighty's specific soil classifications to coincide with vegetational associations. High pinelands were found to coincide with slightly acid Charlotte fine sands while areas around their perimeter were Immokalee find sands which lacked a hard pan. Most of the remainder of the area was either Pompano fine sand under medium height grasses, rushes and sedges or Immokalee Fine Sands covered by Eleocharis cellulosa Torr. 
FLORA AND FAUNA

Tabb et al. (1977) have described the terrestrial flora and fauna of the area between the Belle Meade Grade and MacIlvane Bay. Nine floral associations comprizing 54 species were recognized by the visually dominant species in each. A Pinus elliottii Engelm.-Sabal palmetto (Walt.) association was found on fingers of upland that extended southward from the Belle Meade Grade toward the lake. Surrounding the uplands and extending over much of the northern half of the immediate watershed were sand barrens. Where vegetated, this area was dominated by dwarf Conocarpus erecta (L.) Sesuvium portulacastrum (L.), Distichlis spicata (L.) and Ilonanthochloe littoralis Engelm. There were a few buttonwood hammocks dominated by Conocarpus and Sabal and along the edges of these hammocks a Juncus rocmerianus Scheele - Eleocharis cellulosa association dominated. Depressions emmanating from the uplands were dominated by Juncus and Spartina spartinae (Trin.). Eleocharis and dwarf Rhizophora mangle $L$. dominated much of the remaining area north of the lake with increasing numbers of isolated and connecting ponds of Chara and Ruppia maritima $L$. just north of the main mangrove forest that bordered the lake's northern shore. The Rhizophora forest seemed best developed along the northern shore of the western end of Lake Marco Shores where tree heights average $\sim 4.0 \mathrm{~m}$. 
The Water Surveillance Branch for Region IV of the USEPA has collected field data on water quality and primary production in the lake watershed ( $J$. Moulding, USACE, Jacksonville - personal communication). Between August 21 and September 1, 1978, they measured "wet season" standing crop biomass for several non-woody plant association. At each of four sites (Figure 1) fifteen randomly selected $0.25 \mathrm{~m}^{2}$ samples of the above ground plant matter were collected and separated into live and dead material. After drying in an oven at $105^{\circ} \mathrm{C}$ for twenty-four hours, the samples were weighed for a determination of ash-free dry weight. The results of their work are presented in Table 1. Eighty-two animal species were identified by Tabb et al. (1977) as recent inhabitants of the lake's drainage basin. Included in their faunal list were: Thirty-one bird species, dominated by wading types such as the white ibis, Eudocimus albus (L.), and snowy egret, Egretta thula (I.); seven mammals, dominated by the raccoon, Procyon lotor ( $\left.\mathrm{L}_{*}\right)$, and the rice rat oryzomys palustris (Harlan); nine reptiles and amphibians, dominated by the American alligator, Alligator mississippiensis (Daudin); six fishes, dominated by the mosquitofish, Gambusia affinis (Baird and Girard); numerous insects and two crustaceans, Procambarus alleni (Faxon) and Callinectes sapidus Rathbun. 


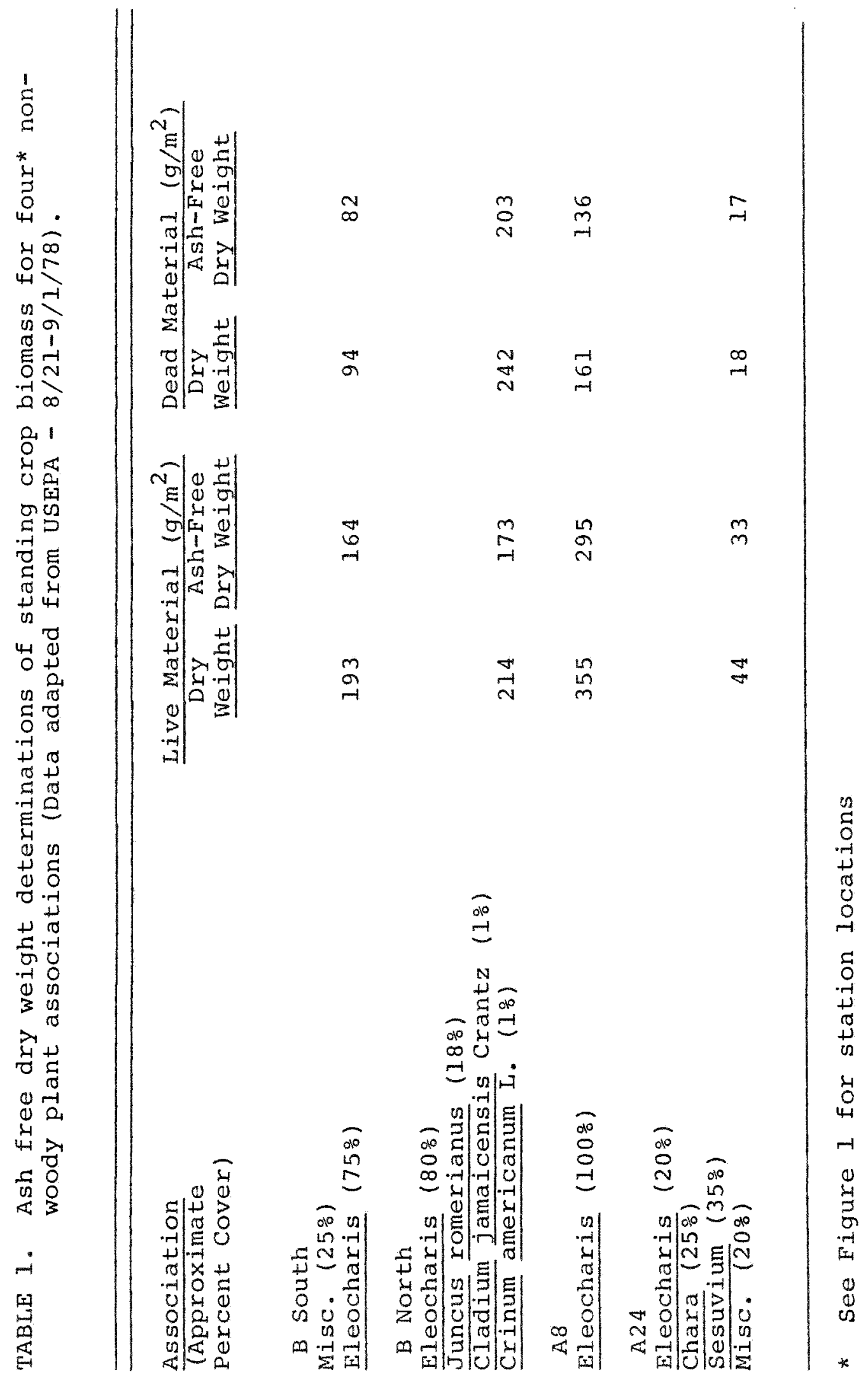




\section{PHYSICOCHEMICAL STUDIES OF LAKE MARCO} SHORES AND ITS IMMEDIATE SURROUNDINGS.

In addition to the faunal and floral studies by Tabb et al. (1977) and studies by the USEPA there have been other recent investigations relating to water quality and quantity in Lake Marco Shores and in its surrounding watershed. The earliest data on lake water quality were collected on December 15, 1972 at a series of stations in the western end of the lake (Paul Larsen - personal communication). Profiles of dissolved oxygen, temperature and salinity were taken in 1.5 meter increments from the surface to the $9.1 \mathrm{~m}$ depth. The results from these observations are presented in Table 2. There was evidence of stratification between $1.5 \mathrm{~m}$ and $3.0 \mathrm{~m}$ even at that early date in the history of the lake. It should also be noted that at the time of those measurements, dredge and dragline work was still going on in the eastern end of the lake.

Appleby and Hatcher (1974) neasured surface $(0.15 \mathrm{~m})$ and bottom $(9.14 \mathrm{~m})$ water at the western end of the lake on a monthly basis from April 1974 to January 1975. In addition to the dissolved oxygen stratification observed by Larsen (between $1.5 \mathrm{~m}$ and $3.0 \mathrm{~m}$ ), the latter study showed a high degree of stratification for salinity, dissolved oxygen, $\mathrm{pH}$, and temperature as well (Figure 3). There was an abrupt change in $\mathrm{pH}$ and salinity between June and JuIy, 1974. Several factors may have caused this abrupt change 
TABLE 2. A sumary* of profile means $(n=6)$ of temperature and dissolved oxygen collected on 15 December, 1972 at the west end of Lake Marco Shores.

\begin{tabular}{|c|c|c|c|c|}
\hline Depth $(\mathrm{m})$ & Tempes & $=\left({ }^{\circ} \mathrm{C}\right)$ & sso & en $(m$ \\
\hline & $\overline{\mathrm{x}}$ & S.D. & $\bar{x}$ & S.D. \\
\hline 0 (surface) & 23.5 & 1.7 & 6.4 & 1.4 \\
\hline 1.5 & 23.9 & 0.2 & 5.5 & 1.5 \\
\hline 3.0 & 23.7 & 0.3 & 0.6 & 0.2 \\
\hline 4.6 & 22.0 & 0.1 & 0.3 & 0.1 \\
\hline 6.1 & 25.1 & 0.1 & 0.3 & 0.2 \\
\hline 7.6 & 24.6 & 0.3 & 0.1 & 0.1 \\
\hline
\end{tabular}

* Data from Paul Larsen - Larsen and Associates 


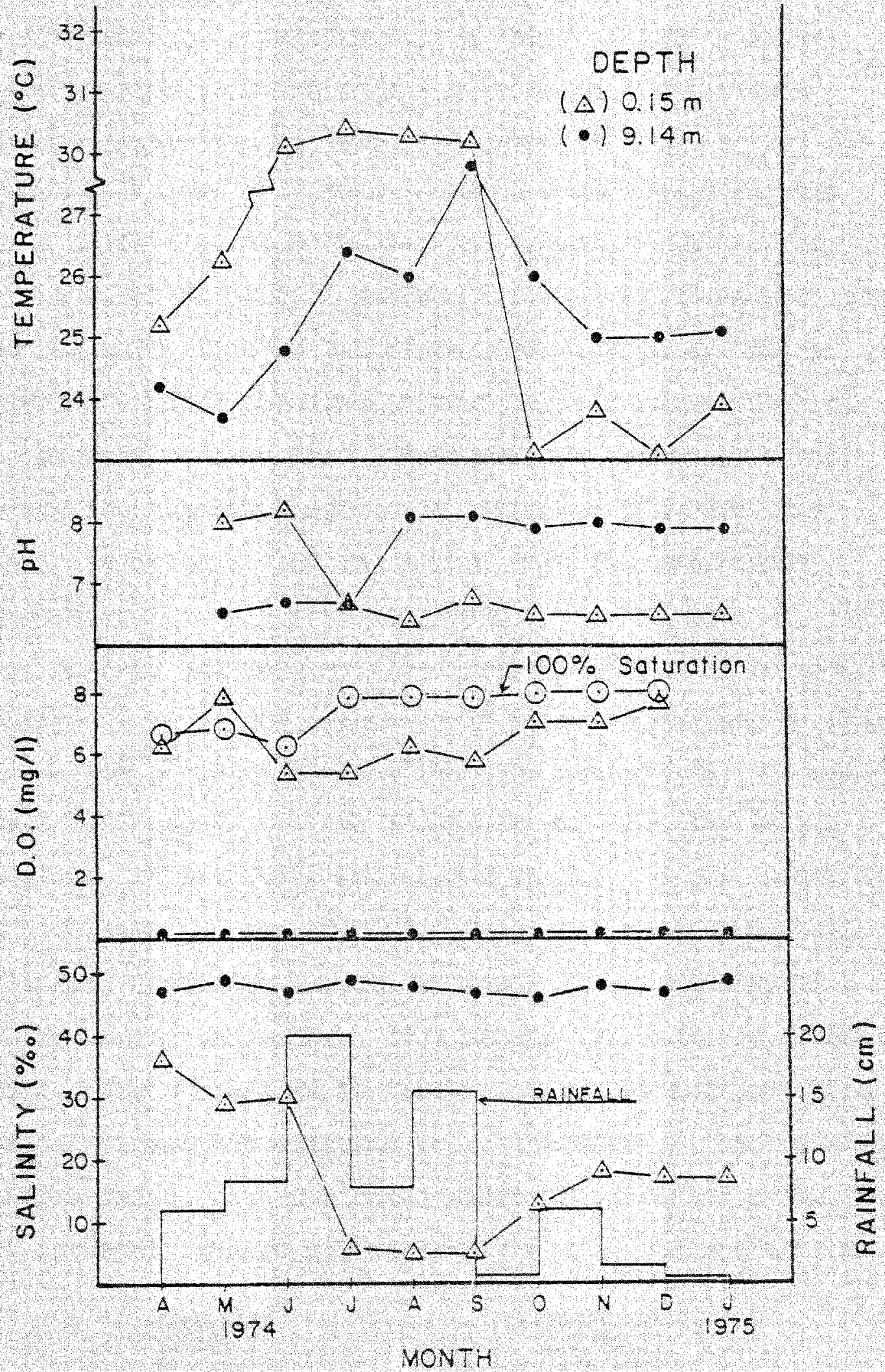

Fig. 3. Surface $(0.15 \mathrm{~m})$ and bottom $(9.14 \mathrm{~m})$ salinity, dissolved oxygen, $\mathrm{pH}$, temperature and rainfall measurements at Lake Marco Shores for the period April, 1974-January, 1975. 
in the vertical structure of the lake. First, a seven month drought in which only $1.8 \mathrm{~cm}$ of rain fell was abruptly terminated in July, 1974 when $20.0 \mathrm{~cm}$ of rain was recorded (Figure 2). This could have depressed surface water salinities from the $31 \%$ level of June to the $5 \%$ level for July. Second, a review of December, 1973 and December, 1974 aerial photographs indicates that a dredge connected the lake to area surface waters east of the present eastern lake shoreline by a temporary canal during the construction of the airport. Although this canal was later filled in, it may have allowed ponded freshwater to drain into the lake.

Appleby and Hatcher (1974) also collected five monthly surface $(0.15 \mathrm{~m})$ and bottom $(9.14 \mathrm{~m})$ water quality samples during the period extending from the end of the 1974 rainy season (September) to the middle of the next dry season (January, 1975). They measured turbidity, color, nitrite$N$, nitrate-N, ammonia-N, orthophosphate, total phosphate, silicate, suspended solids, chlorophyll a, phaeophytin a, and beginning in October, 1974 Secchi transparency. Their results are sumnarized in Table 3. Average bottom values for all parameters measured were significantly higher than surface values although there was no discernable trend over the interval studies at either the surface or the bottom. 


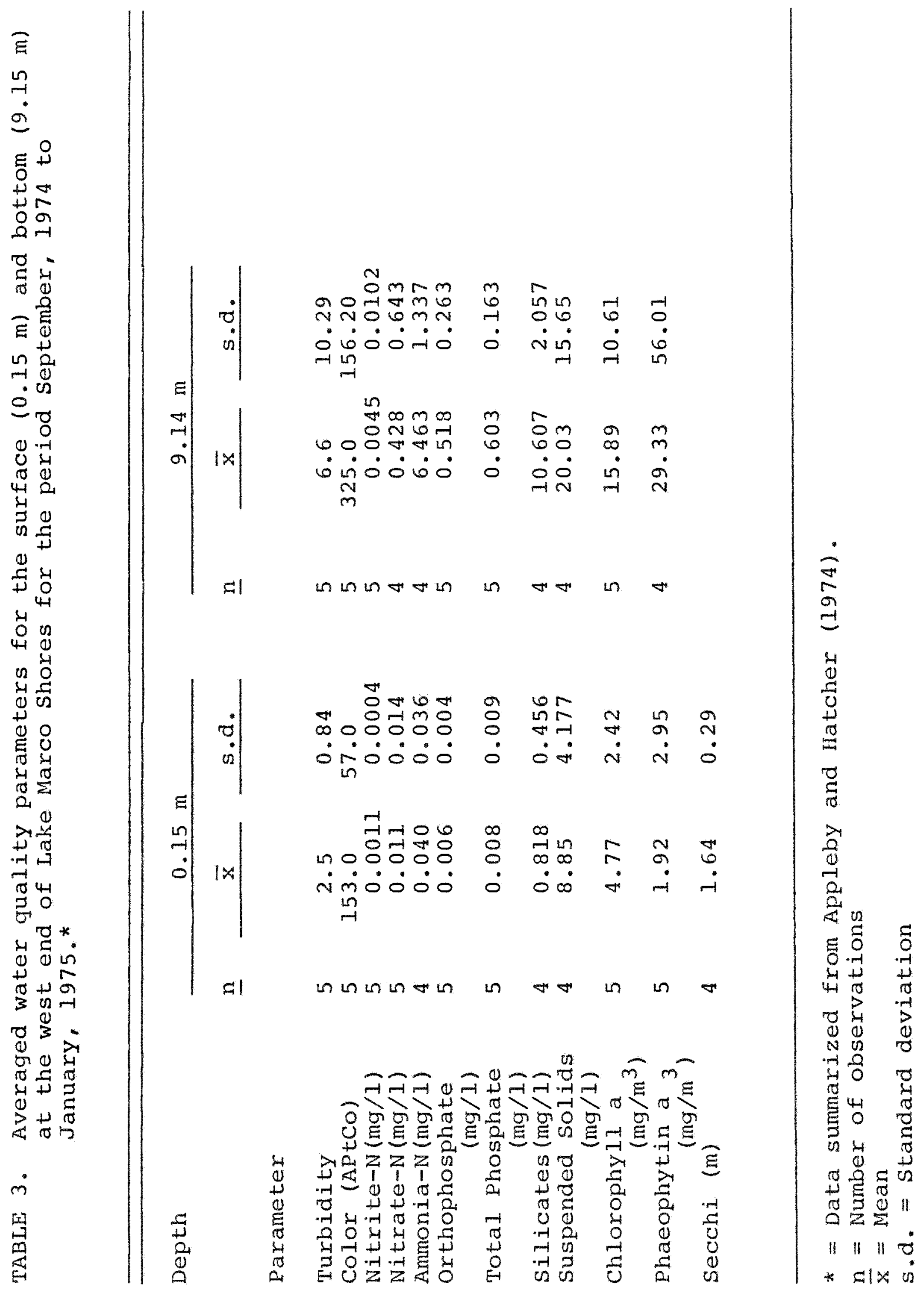


Over the period 28 October 1976 to 21 June 1977 , I conducted seven preliminary profiles of temperature, conductivity, salinity and dissolved oxygen (Figures 4-7) at Station WQ4. Upper layer waters ranged from $17.5^{\circ} \mathrm{C}$ to $32.3^{\circ} \mathrm{C}$ with a pronounced thermocline evident between the $1.8 \mathrm{~m}$ and $3.0 \mathrm{~m}$ depths (Figure 4 ). Temperatures in the lower layer only ranged between $24.0^{\circ} \mathrm{C}$ and $26.5^{\circ} \mathrm{C}$ (Figure 4). Conductivities and salinities (Figures 5 and 6 ) showed lesser variability than temperature, but a definite trend was established over the period as the upper water layer became more saline with the progressing dry season. A halocline was generally evident between the $1.5 \mathrm{~m}$ and $3.0 \mathrm{~m}$ dephts, but June 1977 measurements indicated that with the advent of the rainy season the halocline compressed to the $2.7 \mathrm{~m}$ to $3.0 \mathrm{~m}$ depth interval. Salinities in the lower layer varied little over the period (range $=40-44 \% / 00$ ) and were always hypersaline. Dissolved oxygen always exhibited an clinograde curve (Figure 7) with the upper layer always near saturation.

On 9 January, I also conducted a preliminary chemical profile of 14 parameters from the surface through the thermocline. These data are summarized in Table 4. There were indications of increased acidity along with a highly reducing environment in the lower layer. Of special interest was not only the low levels of chlorophyll in the upper layer $(\bar{x}=$ $\left.7.12 \mu \mathrm{g} / \mathrm{cm}^{3}, \mathrm{~s} . \mathrm{d} .=\mu \mathrm{g} / \mathrm{cm}^{3}\right)$, but also the high levels $(82.77$ $\mathrm{ng} / \mathrm{m}^{3}$ ) that were apparently present at the lower edge of the 


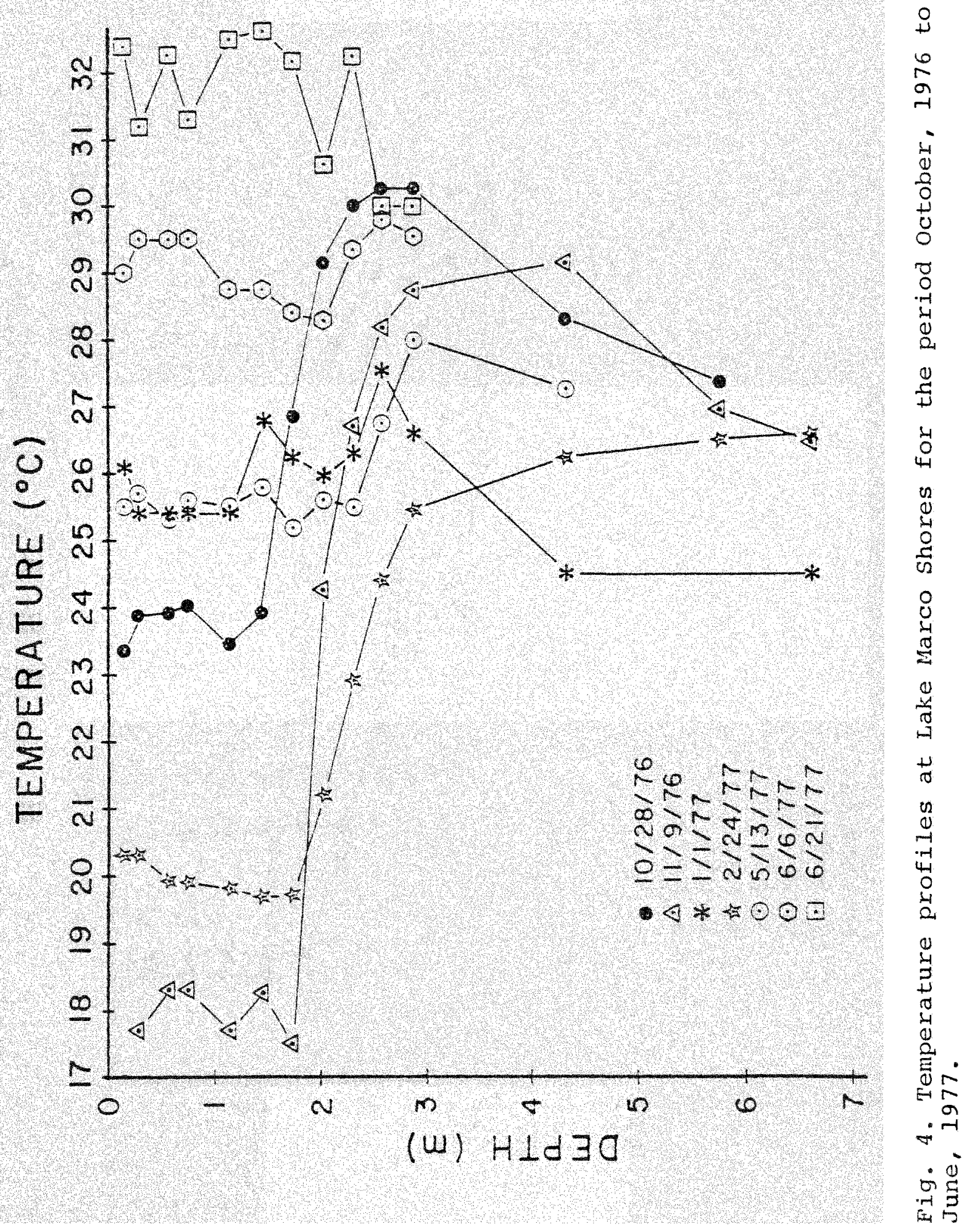




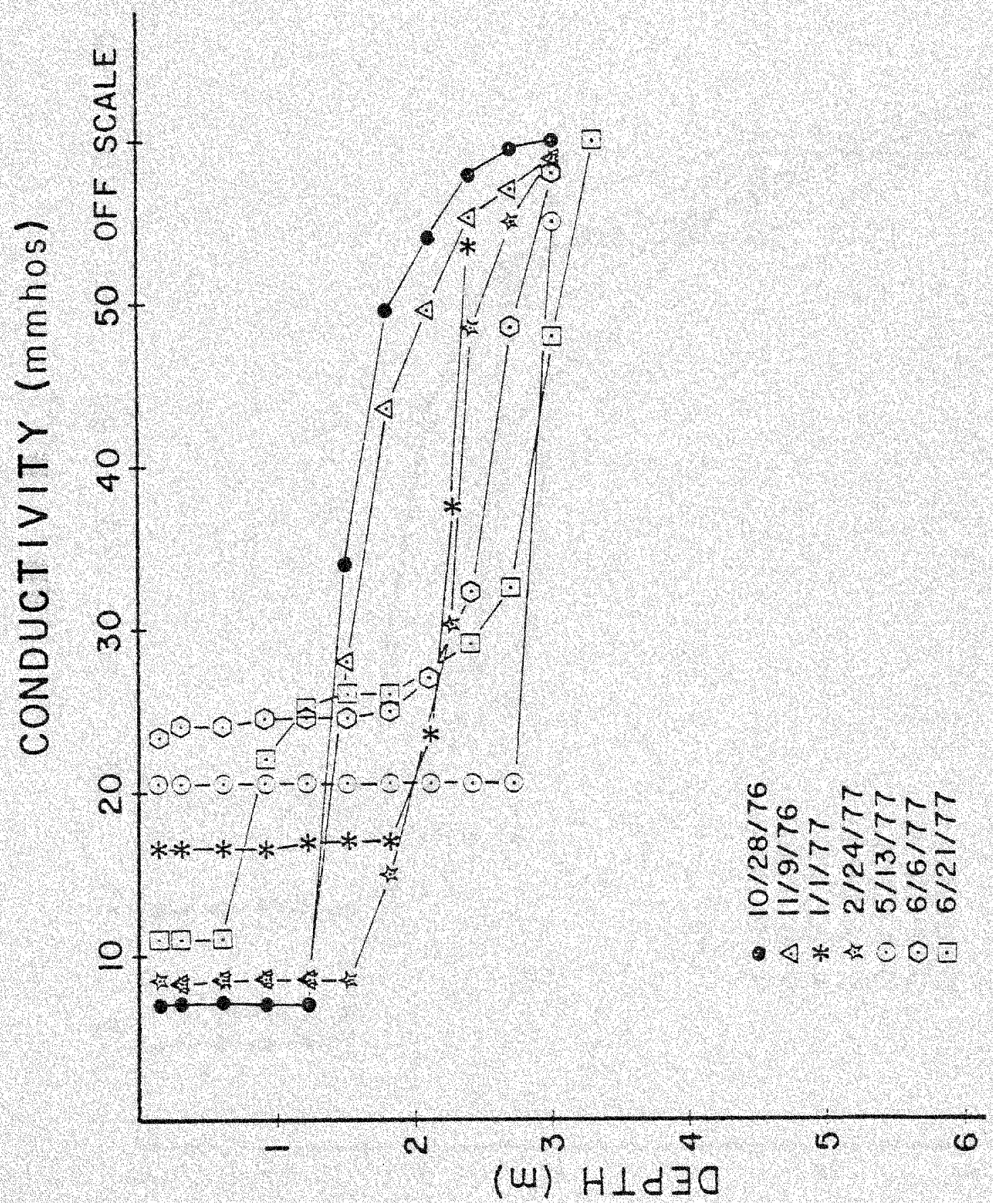




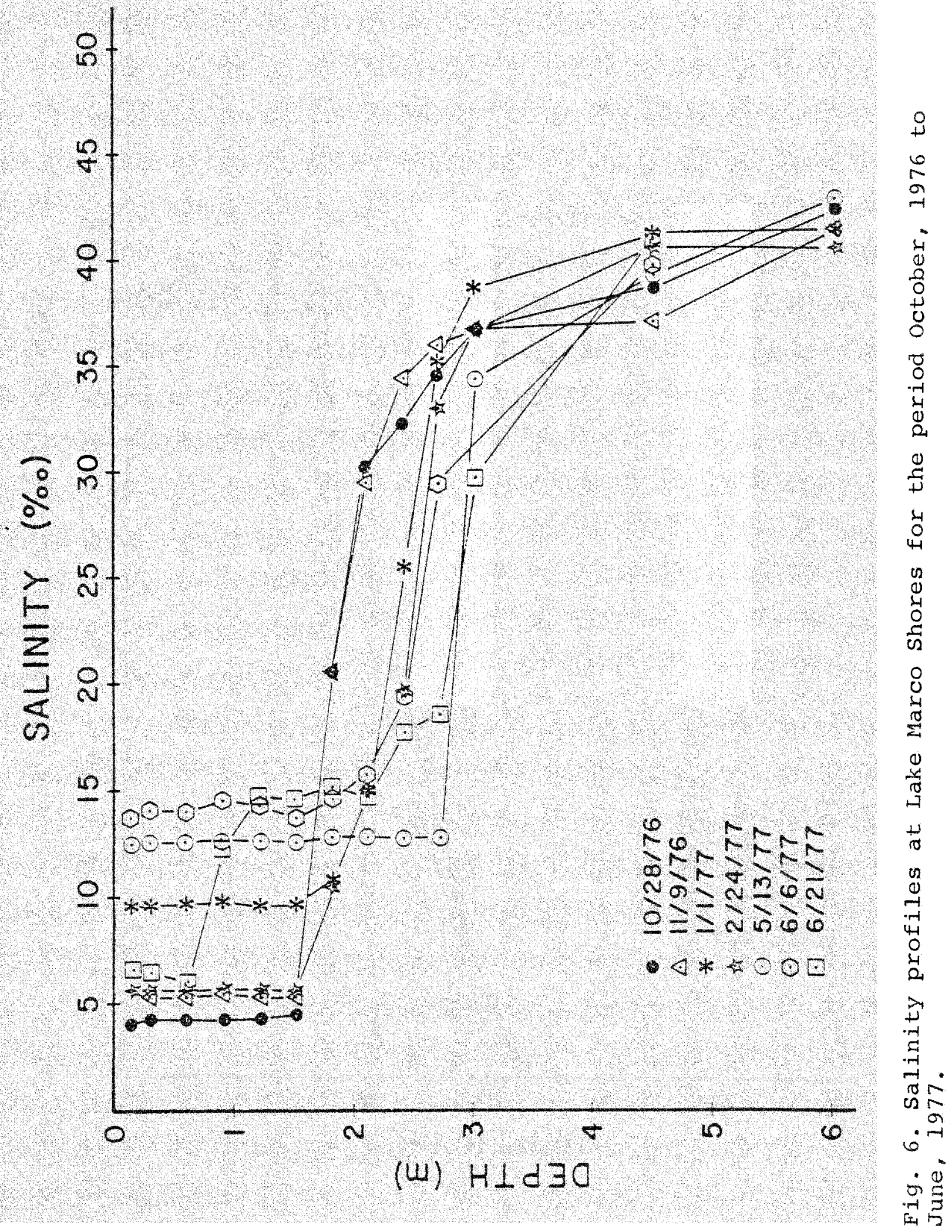




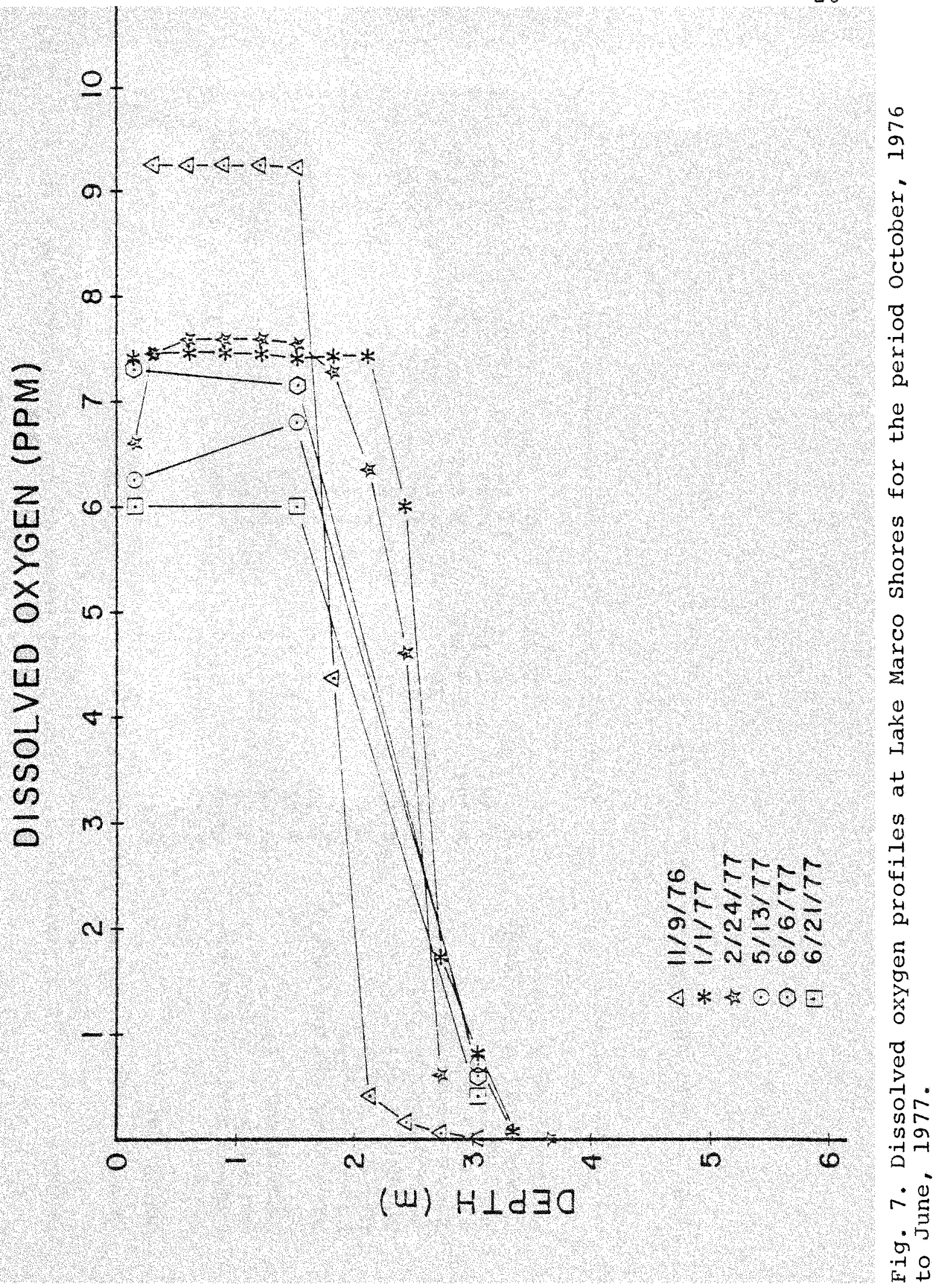




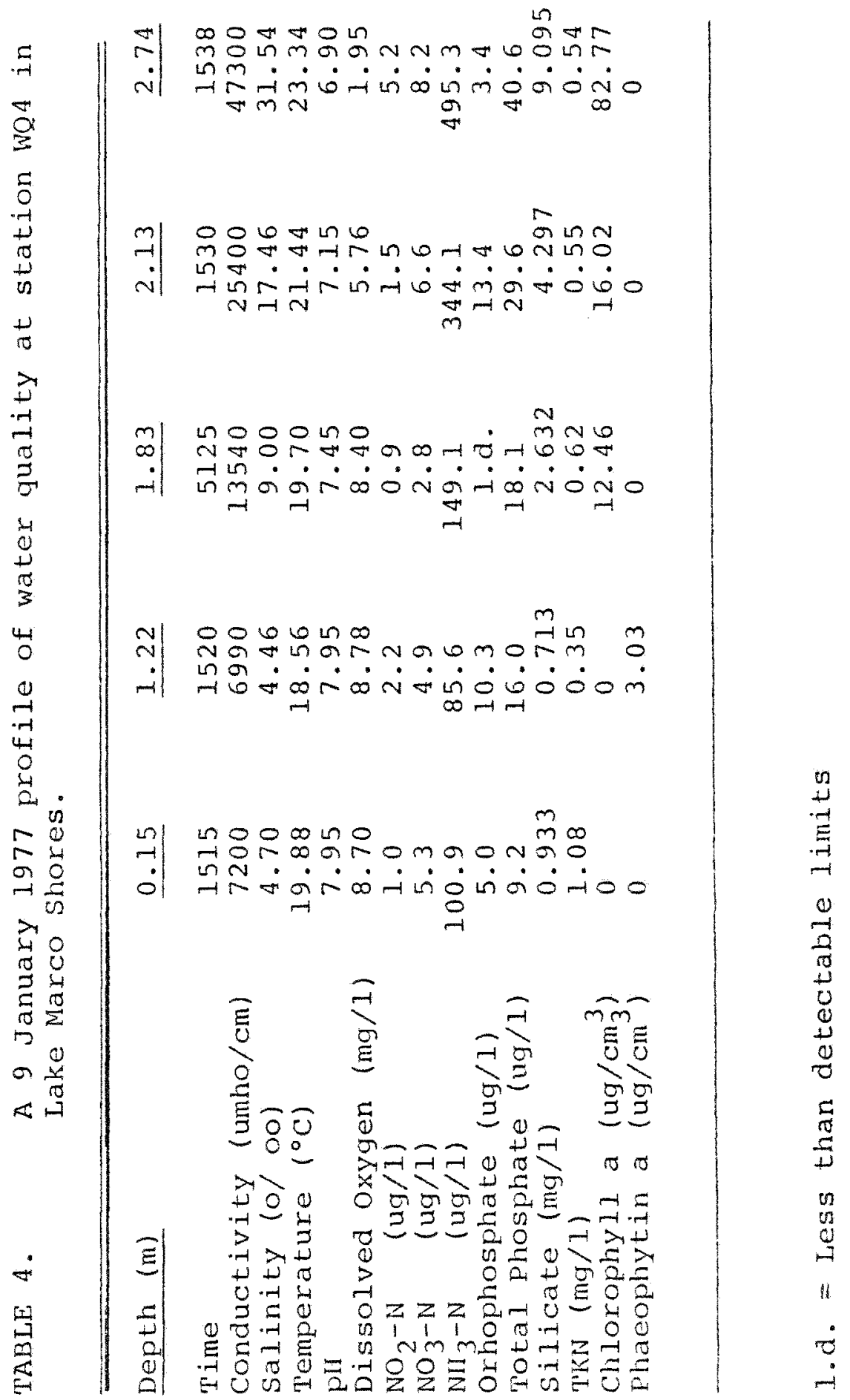


chemocline. In the next section I will describe the methods that I used to study the lake and its watershed. 
In my preliminary profiles of the lake (see Figures 4-7) I had observed three distinct layers, each characterized by a particular set of physicochemical factors. The surface mixed layer, hereafter referred to in the terminology of meromictic lakes as the mixolimnion, was always devoid of thermal, ionic, or dissolved oxygen stratification and usually extended from the surface $(0.15 \mathrm{~m})$ to a depth of 3.00 m. Its lower boundary coincided with the upper limit of the middle layer, the chemocline, which was characterized by unsteady but higher conductivities, decreasing and unstable dissolved oxygen levels, and a high rate of temperature change with depth. The chemocline ranged in thickness from $0.3 \mathrm{~m}$ to $1.0 \mathrm{~m}$ and its lower limit was characterized by higher, but stable, conductivities and a decreased rate of temperature change. The lower layer or monimolimnion was characterized by uniform temperature, high salinity, and no dissolved oxygen.

Since each of the three layers was easily definable by in situ measurement, an intensive sampling program was employed over the period January to December 1978 to describe changes within these layers over an annual cycle. During that interval over 40 trips were made to each of two stations on the lake (Figure 2) to monitor the vertical distribution of the following routine parameters: temperature, conductivity, salinity, dissolved oxygen. Station Wl was located over $3.0 \mathrm{~m}$ 
of water, typical of the sub-basin at the eastern end of the lake. Station WQ4 was located over $9.1 \mathrm{~m}$ of water in the lake sub-basin at the western end of the lake and coincided with the location of both Larsen's, and Hatcher's (1974), as well as my own earlier work. At each station profile measurements were taken at $0.3 \mathrm{~m}$ intervals from the surface $(0.15 \mathrm{~m})$ to the bottom using a specially designed submersible pump (Figure 8 ). Since conductivity was off scale and dissolved oxygen was absent below $3.0 \mathrm{~m}$, only two confirmatory measurements were made at the $4.6 \mathrm{~m}$ and $6.1 \mathrm{~m}$ depths at station WQ 4 . 

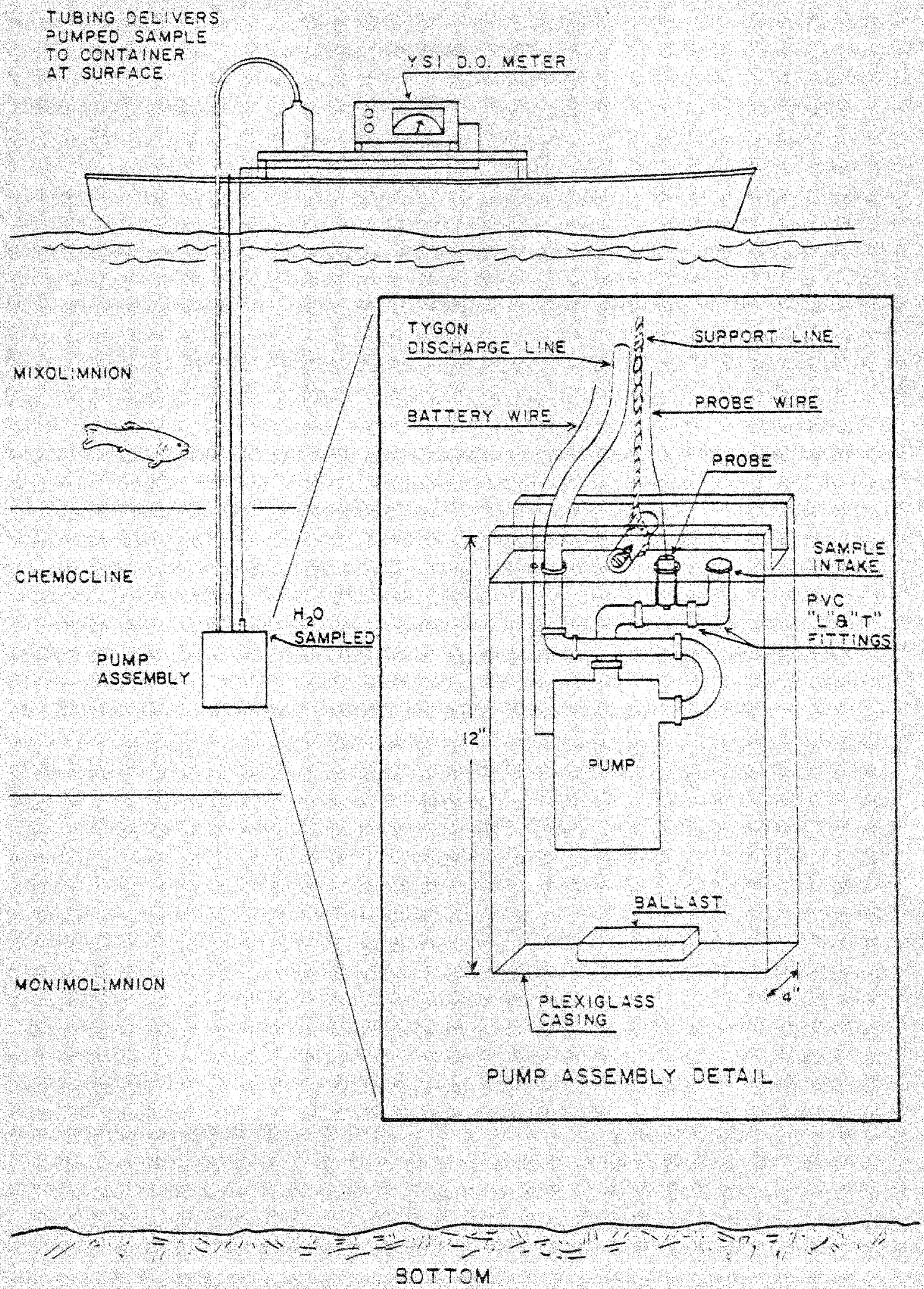

Fig. 3. A specially designed submersible pump used for collecting samples of water and plankton in vertical prufile while allowing for the simultaneous measurement of in situ temperature and dissolved oxygen. 


\section{PHYSICAL PARAMETERS}

Lake Morphometry. The bathymetry of the lake was accomplished during the period october 25-26, 1976 using a Raytheon Model DE-719B Survey Fathometer. The fathometric tracings were transcribed with proper scaling to form a bathymetric map. From this map volume and area relationships were calculated utilizing a $\mathrm{K}+\mathrm{E}$ Model 620000 compensating polar planimeter. The volume of individual lake strata between depths $m$ and $n$ was computed by the method of Hutchinson (1975a) shown in equation 1 .

$$
v_{n-m}=1 / 3 \quad\left(A_{m}+A_{n}+\left(A_{m m} A_{n}\right)^{\frac{1}{2}} \quad(n-m)\right.
$$

where $V$ is the volume of the individual strata ( $m$ and $n$ ) and $A$ is the surface area of the individual strata. 
Climatic conditions. Climatological data were collected at two sites (Marco Island and Rookery Bay) which bracketed the lake at distances of approximately $4.8 \mathrm{~km}$ (Figure I). Rainfall was continuously recorded at both sites on Belfort Instrument Company 5-780 Series weighing rain gages. Additional rainfall data were collected on a weekly basis at two locations in the watershed of Lake Marco Shores and at two locations on the lake shore (Figure 1) using Taylor wedge type rain collectors mounted on staffs which also served as references to monitor weekly surface water levels. It should be noted that the data from these four locations were not continuous since the gages and staffs were frequently destroyed by vandals. In addition to rainfall the following parameters were continuously monitored at the Marco Island site: Wind speed and direction on a Bendix Friez Model 141 Aerovane wind recorder; Air temperature on a Taylor Model 2354 recording thermometer; and Solar radiation on a Weathermeasure Model R401 mechanical recording pyranograph. The quality of rain water inputs to the lake was based on the analysis of three storm water collections at the MAMES ( 31 May, II July and 8 August). On each occassion nitratenitrogen, and total phosphate were measured. Ammonianitrogen and chloride were also measured on samples from the latter two storms. 
Lake sediments. The surficial sediments $(0.3 \mathrm{~m})$ at the lake received two treatments. Sediments from the shore, $0.2 \mathrm{~m}, 0.3 \mathrm{~m}, 0.6 \mathrm{~m}, 1.2 \mathrm{~m}, 1.5 \mathrm{~m}$, and $3.0 \mathrm{~m}$ depths were collected and analyzed for size and organic compositon on 27 March 1977. At each of these depths a $1.0 \mathrm{~m}$ long plexiglass tube (inside diameter $=5.1 \mathrm{~cm}$ ) was pushed into the substrate and removed with an intact vertical sediment sample profile. The top $20.3 \mathrm{~cm}$ of the core was dried and then fractionated with a set of Tyler (U.S. Standard) sieves. Representative samples of each sediment fraction were ashed at $550^{\circ} \mathrm{C}$ for one hour in a Thermolyne Type 1500 muffle furnace to determine organic content.

A soft silt-like sediment predominated in the deeper $(>3.0 \mathrm{~m})$ portions of the lake. A grab of this sediment was collected using an anchor and later analyzed by Dr. James Charlesworth, University of Toledo, for its major constituents using $x$-ray diffraction. 
Hydromechanics. My early profiles at the lake suggested that a sharp density gradient existed across the chemocline with a stable mixolimnion and monimolimnion existing above and below it, respectively. Johnson (1946, 1949) in modeling such a stratified system has noted that winds can set the top layer up in the downwind direction causing the upper part of the lower layer to flow in a direction contrary to the wind. If mixing induced by such circulation occurred, repetitive profile measurements of the mixolimnionic waters would possibly detect it as an increase in salinity correlatable to a period of intense wind activity. wind intensity, however, combines with other factors such as fetch and wind duration to generate the waves which ultimately influence circulation (King, 1963). A linear regression was performed on the 40 weekly profile data set from station WQ4 to determine if mixolimnion salinity was highly correlated with rain and wind events. Average salinity of the mixolimnion on the sample date was used as the dependent variable against each of the following independent variables occurring over the seven day period prior to each sample date:

Total rainfall; and The number of hours of wind speed in excess of $24 \mathrm{~km} / \mathrm{h}$ from each of the following directions $\left(045^{\circ}-090^{\circ}\right.$, and $\left.225^{\circ}-270^{\circ}\right)$.

The results of these regressions are presented on page 67 .

On each trip to the lake actual wave heights were measured against a fixed staff at the eastern end of the 
36

lake for comparison with maximum theoretical values. The fetches that would be expected to have the greatest effect on circulation in Lake Marco Shores are long $(881 \mathrm{~m})$ in comparison to their width $(225 \mathrm{~m})$. The fetch width in such cases becomes quite important resulting in wave generation significantly lower than that expected from the same genprating conditions over more open waters (Anon., 1975b).

The method of Saville (1954) which incorporates the effect of fetch width on wave height was used to determine theoretical wave heights. 
Hyärology. Lake Marco Shores was seasonally joined to the fresh surface water on the north side of the lake. While an effective equilibrium slope exists on the lake's eastern, southern and western shores as the result of construction of the Marco Shores Golf Course, Airport and associated dikes, on the northern shore the basin slope extends to only a $+0.8 \mathrm{~m}$ (NGVD) elevation allowing for no true beach. Four staffs were installed in the lake and drainage area north of the lake (Figure I) to measure fluctuations in surrounding surface water levels relative to lake water levels. The water level at each staff was generally read on a weekly basis during the period January to December, 1978 .

Tides in the Marco vicinity are of the mixed variety with diurnal inequalities. In an attempt to determine if the lake was in weak tidal communication with MacIlvane Bay via the SR 951 canal, Fisher-Porter recording tide gages were emplaced at the lake during January, 1977 and at the mouth of the SR 951 canal where it joins MacIlvane Bay.

Daddio and Van de Kreeke (1979) have studied the flux of dissolved organic carbon emmanating from the area north of the lake and to the east of SR 951, and their work provides an insight into the gross water movements from the general area of the lake and its watershed. They estimated monthly net water discharges by measuring head differences 
across three culverts which join the northern and southern sections of the SR 951 canal under the golf course access road. A net flow to the south was defined, but seasonal variations in the amount of this net flow ranged from 3.51 $\times 10^{6}$ cubic meters in July 1977 to $2.69 \times 10^{5}$ cubic meters in November 1978. If total rainfall for that period (Rookery Bay data) were extrapolated over the drainage area, $2.23 \times 10^{7}$ cubic meters of rain water were not discharged according to their calculations at the culverts. However, annual pan evaporation from this type of area could be expected to range from $123 \mathrm{~cm}$ to $155 \mathrm{~cm}$ (Carter et al., 1973), and this in itself (disregarding transpiration) could account for up to $3.32 \times 10$ cubic meters of water loss. This indicated that additional ground water ( $1.09 \times 10^{7}$ cubic meters) was entering the area or that measured discharges consisted of both surface and ground water runoff. Nevertheless, in plotting monthly rainfall versus monthly discharge they did show that the pattern of rainfall was similar to that of runoff with a general excess of rainfall over runoff during the early months of the rainy season (April, May, June) and with runoff far in excess of rainfall for the rest of the year. A Texas Instruments $51 \mathrm{~A}$ calculator was used to regress total monthly rainfall on their computed nonthly discharges for the period (Figure 9). The correlation was not high because of the lags that occurred between rainfall and runoff. 


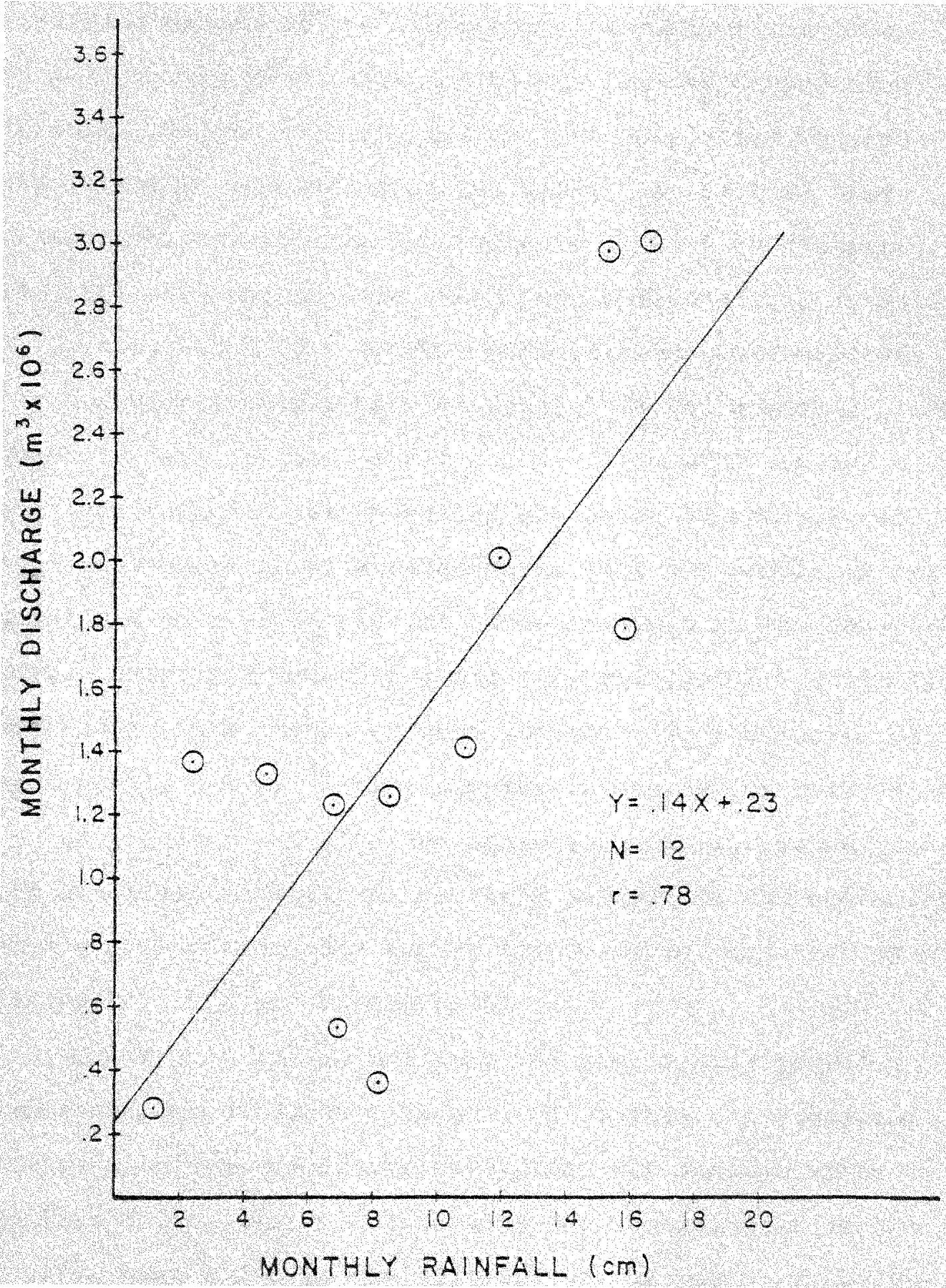

Fig. 9. A regression of total monthly discharge* at the SR 951 culverts on monthly rainfall as recorded at Rookery Bay. *Adapted from Daddio and Van de Kreeke (1979). 
With evidence that substantial volumes of water were being discharged to the south of the lake and given the confining nature of the topography surrounding the lake 20 well points were installed by The Deltona Corporation in June, 1978 to test for qualitative continuity between the lake and surrounding ground water. At each of five stations bracketing the lake (Figure 1) $18.0 \mathrm{~cm}$ diameter PVC pipe well points were installed at depths $1.22 \mathrm{~m}, 2.13$ $\mathrm{m}, 5.18 \mathrm{~m}$, and $7.62 \mathrm{~m}$ (NGVD). The stations were visited on an irregular basis between July, 1978 and December, 1978. On each visit $(n=13)$ the elevation of the water inside the pipe was measured before all of the water in the pipe was evacuated by means of a parastaltic pump. A sample of new water was then withdrawn for later analysis in the laboratory. Samples from every visit were analyzed for salinity, chlorides, turbidity and color according to the method of Rand et al. (1976). Three samples in the series were collected simultaneous with the collection of lake water quality profiles. Additional nutrient parameters and magnesium were analyzed from this series according to the methods of (USEPA, 1974 and USEPA, 1976b).

Early profiles in the lake and preliminary ground water quality evidence from the well points had indicated that the salt water intrusion typical for coastal areas of Collier County (Klein, 1954) might be occurring at depths greater than $2.0 \mathrm{~m}$ in the vicinity of the lake. This, to- 
gether with the suggestion in the work of Daddio and Van de Kreeke (1979) of possible counter flow of fresh water in the surface aquifer, prompted the initiation of a series of measurements of ground water seepage over the period 4 December, 1978 to 6 March, 1979. On 4 December, $1978 \mathrm{six}$ seepage meters (Lee, 1977) were installed at the $0.5 \mathrm{~m}$, $1.5 \mathrm{~m}$, and $3.0 \mathrm{~m}$ depths in the littoral zone of the lake's northern shore (Figure 2). Collections at this site were repeated on nine more occasions in December and once in January. If seepage occurred, samples were collected from the meter and returned to the laboratory for analysis. Similar measurements were made at comparable depths on the southern shore of the lake (Figure 2) on 8 January and 6 March, 1979. A third set of measurements were collected on 7 March, 1979 on either side of the dike (Figure 2) at the western end of the lake. Finally, a fourth set of measurements (9 March, 1979) were made on the eastern side of the SR 951 canal and in the southernmost canal of the Port au Prince trailer park.

Seepage water was usually analyzed for only chloride content, but total organic carbon, magnesium, ammonia-N, nitrate-N, nitrite-N, total kjeldahl-N, total phosphate, pH, salinity, turbidity, color and hydrogen sulfide presence were also tested on occasion by the method of Rand et al. (1976a). 
Optical and thermal properties. On each of the 40 trips to the lake a standard Secchi disk was used to estimate the depth to which 5 percent of the incident solar radiation penetrated.

On 20 January an overnight, continuous profile of temperature at Station WQ1 was made to a depth of $3.5 \mathrm{~m}$ in $0.3 \mathrm{~m}$ increments using a YSI Model 47 Scanning Telethermometer coupled to a YSI Model $80 \mathrm{~A}$ Single Channel Laboratory Recorder. 


\section{CHEMICAL PARAMETERS}

In addition to the results of the 40 profiles of dissolved oxygen, temperature, salinity and conductivity the description of the water chemistry of Lake Marco shores was also based on a series of twelve monthly nutrient profiles. All samples were collected by submersible pump from three depths at stations WQI and WQ4 (Figure 2). The depth from which each sample was taken was relatively constant over the 12 month period, but varied slightly $( \pm 0.5 \mathrm{~m})$ for chemocline and monimolimnion samples so as to adequately represent the water quality in these strata as their depths fluctuated with time. Samples were always collected from the $0.15 \mathrm{~m}$ depth to represent the mixolimnionic waters. Chemocline sample depths were always collected from the first depth interval $(0.3 \mathrm{~m})$ at which conductivity increased by greater than 25 percent (usually $2.4 \mathrm{~m}-3.0 \mathrm{~m}$ ). This depth also coincided with decreased levels of dissolved oxygen and general instability in both conductivity and oxygen meter measurements. The sample chosen to represent monimolimnetic waters was always collected at the first depth interval at which anoxia was evident (usually $3.0 \mathrm{~m}-$ $3.6 \mathrm{~m}$ ) or at a depth of $0.15 \mathrm{~m}$ above the bottom, whichever came first.

Nutrient samples from the lake and all other water quality sampling programs (i.e. well points and seepage 
meters) were immediately refrigerated in the field to $4.0^{\circ} \mathrm{C}$ in polyethylene bottles and transported to the laboratory for analysis within 24 hours. A Beckman Model 24 Dual Beam Spectrophotometer was used to measure absorbance for all spectrophotometric methods.

Chemical analytical methods followed: USEPA (1974) for nitrite- nitrogen $\left(\mathrm{NO}_{2}-\mathrm{N}\right)$ and nitrate-nitrogen $\left(\mathrm{NO}_{3}-\mathrm{N}\right)$; Rand et al. (1976a) for ammonia-nitrogen $\left(\mathrm{NH}_{3}-\mathrm{N}\right)$, total phosphorous $\left(\mathrm{TPO}_{4}\right)$, total orthophosphorous $\left(\mathrm{OPO}_{4}\right)$, Chlorophyll a, phaeophytin a, sulfate, sulfide, and chloride; and Strickland and Parsons (1972) for soluable organic nitrogen (TKN) and reactive silicate. Hydrogen sulfide was merely noted as being present or absent based on the odor of the sample at the time of collection. Calcium carbonate hardness was analyzed by the method of USEPA (1975a).

Chloride concentrations and cloride to magnesium ratios were chosen as the prime indicators of the origin of lake and ground waters since they are conservative and well known for oceanic waters (Sverdrup et al. 1942). On 22 February, 1978 a two sample profile $10.15 \mathrm{~m}$ and $2.1 \mathrm{~m}$ depths) of dissolved metals was obtained at station WQ4. These analyses involved the use of a Varian Model 375 Atomic Absorption Spectrophotometer equipped with a CRA-90 Carbon Furnace. Total magnesium, copper ( $\mathrm{Cu}$ ), iron (Fe) and manganese (Mn) concentrations were also determined from a later three sample profile (8 November, 1978) at 
stations WQI and WQ4 on a Varian Model 575 Atomic Absorption spectrophotometer according to the methods of USEPA (1974). 


\section{BIOLOGICAL PARAMETERS}

During the study period regular biological collections were restricted to: 1) plankton collections coincident with weekly physicochemical profiles at station WQ4; 2) periodic measurements (1 January 1978, 4 April 1978, I June 1978, and 29 August 1978) of community metabolism by light and dark bottle and diurnal curve methods; and 3) bimonthly collections of the lake's littoral benthic macrofauna. Other non-repetitive studies included: 1) Attempts to determine and compartmentalize benthic community metabolism; 2) A verification of the disjunct nature of the lake's fauna when compared to the fauna of adjacent surface waters (i.e., SR 951 canal and the contiguous surface waters to the north of the lake); and 3) A standing crop determination of the lake's dominant littoral flora, Ruppia maritima on 14 March, 1978. 
Plankton collections. A series of 40 plankton collections were made at stations $W Q 1$ and WQ4 simultaneous with the measurement of vertical physicochemical profiles. Four of these daylight (1000-2000 hours) collections were duplicated at midnight to detect differences between the day and nighttime locations of selected zooplankters. A series of 12 monthly collections from station WQ4 were analyzed simultaneously with nutrient profiles. Additional collections were analyzed to confirm trends observed in the monthly samples and to document consistency between the two ends of the lake. One liter samples were collected with the submersible pump (Figure 8) from the same depths as previously described for nutrients.

Whole plankton samples were preserved with 5 percent formalin. Five ml of a 20 percent commercial detergent solution plus Rose Bengal dye were added to the samples as an aid to counting and recognition. Preserved samples were returned to the laboratory and placed on a shelf in reduced sunlight for $48 \mathrm{~h}$ to allow for sedimentation. The plankton sample was then filtered through an ultra fine plankton net (83 mesh $\mathrm{cm}^{-1}$ ) and washed into a vial for later counting. All samples from station WQI used a Sedgewick-Rafter counting chamber at a magnification of 200x. Samples from station WQ4 were analyzed by Mr. Neil Gillies and Steve Lanley of Connell, Metcalf and Eddy. zooplankton from these samples were counted, after aliquoting with a Langford plankton subsampler. 
Metabolism studies. Five methods were utilized for gathering information on primary productivity and respiration in the water column and on the bottom of the lake. The primary production and respiration of plankton in the water column was measured by the Light and Dark Bottle method (Gaarder and Gran, 1927) on six occasions in 1978 (13 February, 5 April, 12 May, 6 June, 29 August and 5 October) at station WQ4.

Benthic periphyton production was measured on 13 August 1978 by artificial substrate culture. During the period 31 July to 13 August a series of replicate microscope slides were suspended at the $0.15 \mathrm{~m}, 1.8 \mathrm{~m}, 2.1 \mathrm{~m}$ and $3.0 \mathrm{~m}$ depths in the water column by the method of Nielson (1953) and later analyzed by the Chlorophyll and Phaeophytin method (Rand et al. 1976a).

Overall metabolism of the water column was measured in a variety of standing water habitats to the north of the lake. The method of odum and Hoskin (1958) was utilized in a Chara sp. pond northeast of the lake (Figure 1) during the period 17-18 November 1976. During the period of 28-30 August 1978 the USEPA (Dr. Jon Moulding-personal communication) measured overall community metabolism in the water column at four stations in the lake's watershed (Figure 1) by an adaptation of the method of Odum and Hoskin which involved the use of a floating diffusion dome apparatus (Hall, 1971) for measuring atmospheric transfer.

I measured overall community metabolism in the water 
column at station $W Q 4$ in Lake Marco Shores by the method of Odum and Foskin (1958) on four occasions: 31 January-1 February 1978, 4-5 April 1978, 31 May-1 June 1978, and 29-30 August 1978. At two hour intervals conductivity, salinity, temperature and dissolved oxygen were measured in $0.3 \mathrm{~m}$ vertical increments. Salinity and conductivity were measured with a Beckman RS 5-3 Salinometer or an American Optical temperature compensated, refractometer. A Yellow Springs Instrument (YSI) Company Model 57 Dissolved Oxygen Meter was used for temperature and dissolved oxygen measurements. The meter was fitted to a submersible pump and calibrated (before each study and every eight hours during the study) at the laboratory by reference to triplicate Winkler titration of an air saturated fresh water bath.

In addition to the USEPA's standing crop biomass estimates of different types of macrophytic communities in the lake's watershed $(8 / 21-9 / 1)$ a single measurement of the standing crop biomass of Ruppia maritima was made on 14 March, 1978. This species is the floral dominanant of the Lake's littoral zone. Ash free dry weight determinations (Vollenweider, $1974)$ were made for a series of 20 replicate $(0.02 \mathrm{~m})$ core samples.

Attempts to determine benthic community metabolism in the lake were made on four occasions in 1978; 14 February, 23 February, 5 April, and 7 June. On each date a specially designed benthic flume (Carpenter, 1973) coupled to a YSI Model 57 Dissolved Oxygen Meter (Figure 10) was placed on 
the lake bottom at the $0.5 \mathrm{~m}, 1.5 \mathrm{~m}$, and $2.7 \mathrm{~m}$ depths, and the rate of change of oxygen within the unshielded flume compartment was measured over the period 1000-1100 hours. The flume was then covered with a black, opaque cloth shield and the rate of change of oxygen was again determined for a one hour interval (1100-1200 hours).

These measurements were to provide estimates of net production and respiration in discreet lake bottom areas according to the equation:

Net Production

$$
\underset{\text { or }}{\text { piration }}\left(\mathrm{mg} / \mathrm{m}^{2} \mathrm{~h}\right)=\frac{\Delta \text { in D.O. }(\mathrm{mg} / \mathrm{l}) \mathrm{V}(\mathrm{L})(60 \mathrm{~min})(\mathrm{h})^{-I}}{\mathrm{t}(\mathrm{min}) \mathrm{A}\left(\mathrm{m}^{2}\right)}
$$

where $V$ and $A$ are the volume and the area of the flume in liters and square meters, respectively and $t$ is the time of incubation. Then in an effort to compartmentalize the oxygen demand into the chemical demand required by the sediment, as well as bacterial and benthic community respiration, an adaptation of the methods of Smith et al. (1972) was employed.

A concentrated penicillin - streptomycin solution (50 $\mathrm{mg} / \mathrm{l}$ ) was injected via a hypodermic syringe into the flume through the tygon tubing (Figure 10) to detect changes in the rate of oxygen utilization attributable to the bacteria within the flume. A second injection of formaldehyde was made for the purpose of quantifying the chemical oxygen demand of the lake sediments.

Unfortunately, the method employed for benthic oxygen 


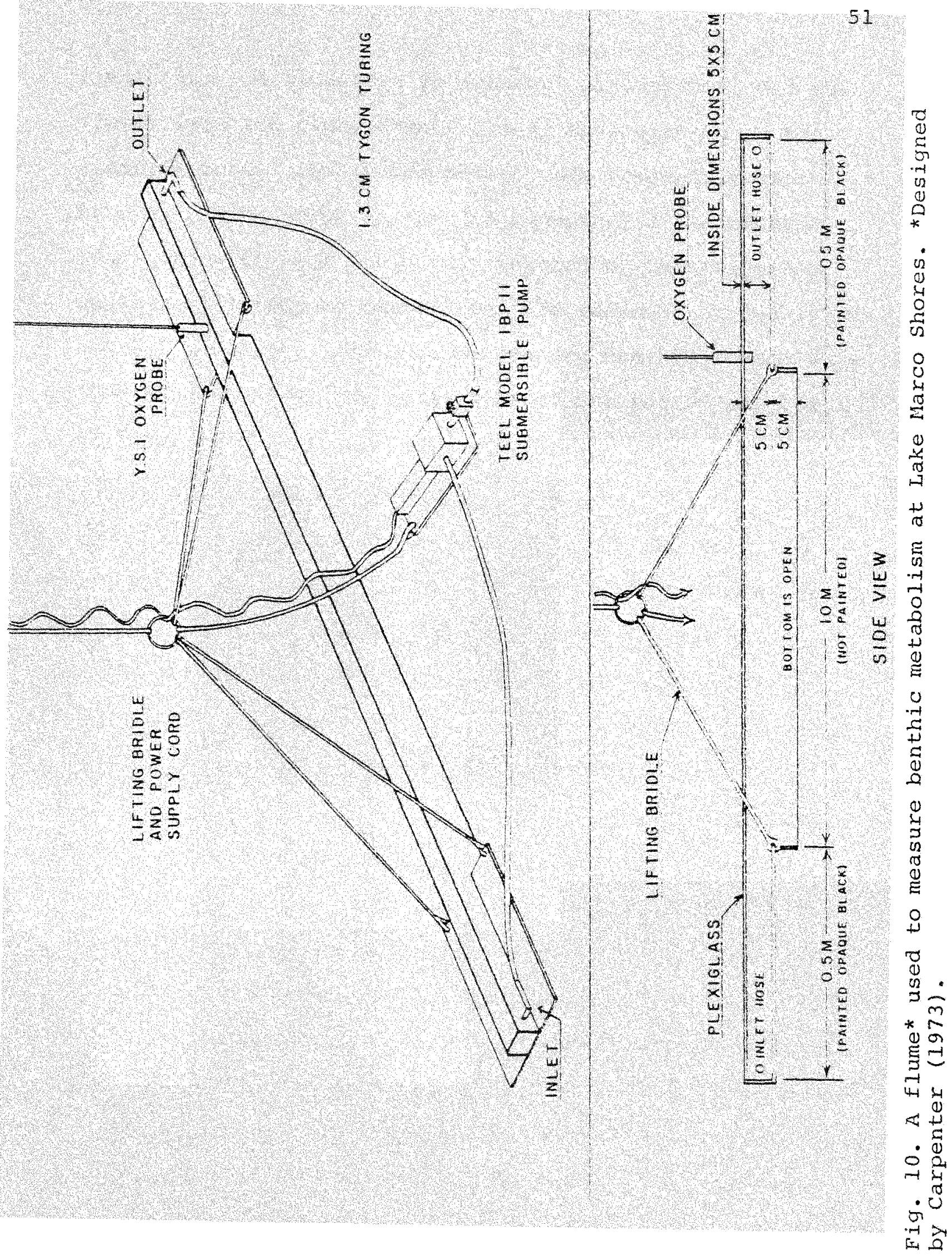


demand was too sensitive to external disturbance, and the flumes were too cumbersome for easy manipulation in the littoral zone. The opaque covers were frequently overturned by wave surge at the $0.5 \mathrm{~m}$ depth and the experimental results were frequently negated by the release of bubbles of entrapped gasses from the sediment at the $1.5 \mathrm{~m}$ and $2.7 \mathrm{~m}$ depths. Attempts to measure benthic demand were discontinued after the collection of one set of samples (7 June, 1978). 
Benthic Macrofauna. I initiated a preliminary infaunal sampling program to quantitatively describe the assemblage present in each strata. This was done for two reasons: 1) physicochemical data suggested that the lake was vertically stratified; and 2) the substrates appeared to vary with depth. As a result of the dragline and dredging methods which were employed in the construction of the lake, it was not unusual to find the littotal zone poorly developed over much of the lake (i.e., slopes of $\sim 1: 1.5$ ). At the eastern end of the lake there was a shallow slope $(7: 1)$ from the shore-water interface to the $3.0 \mathrm{~m}$ depth. In that area, a 7 station transect was established from the beach to the $3.0 \mathrm{~m}$ depth with each station representing a different depth interval. A $1.02 \mathrm{~m}^{2}$ plus corer, developed by Taylor and Saloman (1968), was used to sample the infauna at each station. On 5 January, 1977, it was determined on the basis of an intensive (20 core) random sampling of the littoral zone that a minimum of 5 cores would be necessary to account for 90 percent of the species present (Figure 11). Fiftyone samples were proportionally allocated among the 7 stations according to the estimated area of the littoral zone falling within such depth interval and with a minimum of 5 cores at any station. The preliminary 51 core, infaunal sample was collected on 10 January, 1977, when the lake was at a maximum elevation (Figure 16). The contents of each core were washed through a $0.701 \mathrm{~mm}$ sieve; the retained organisms were preserved in a $20 \%$ buffered formalin solution, 


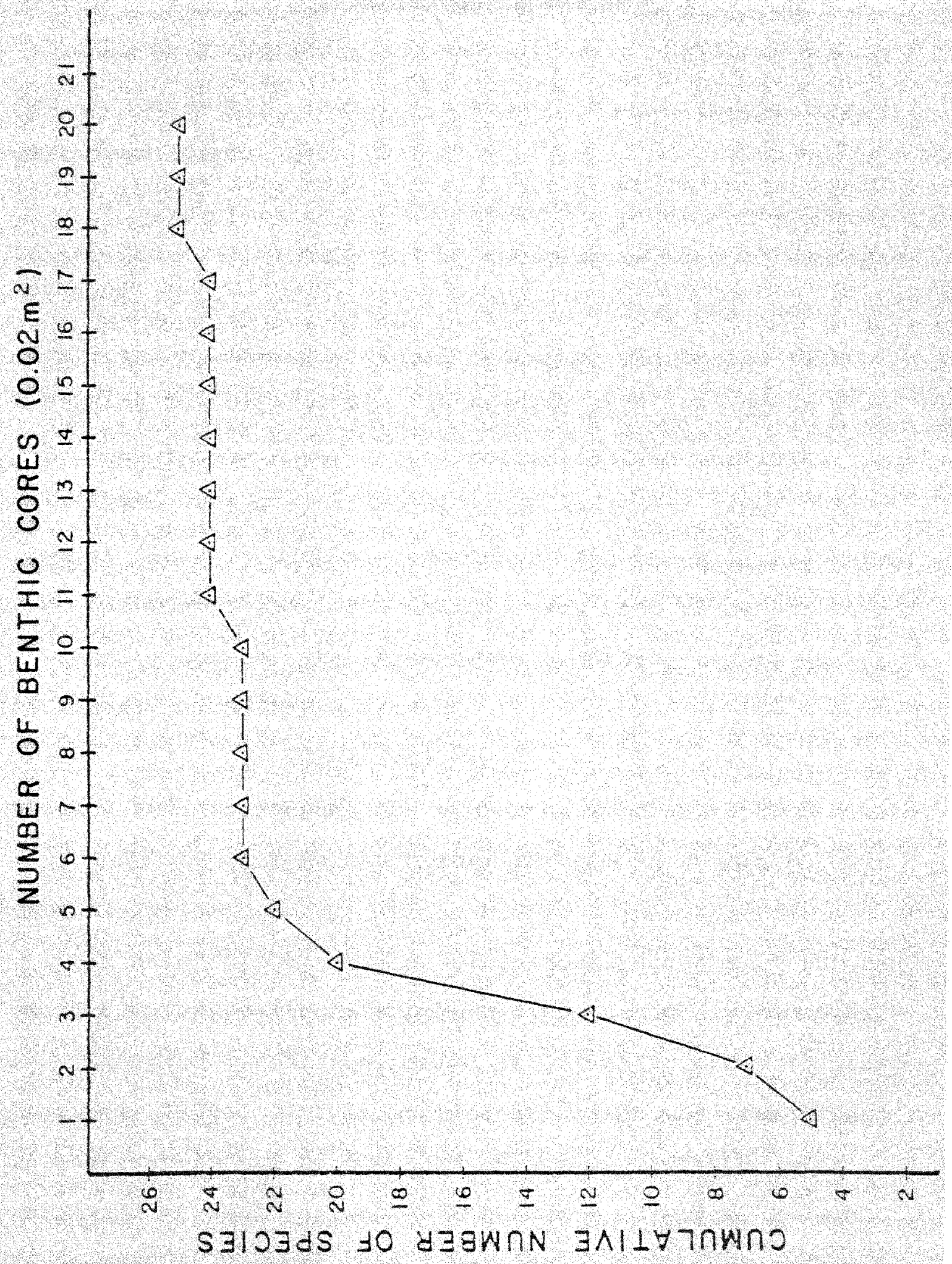

स 
and subsequently sorted, identified and counted. A second series of samples was collected on 2 April, 1977, when the lake was at a low elevation. On this date I also collected macroinvertebrates from a 4 station transect in the lake's watershed (Figure 2).

On I June, 1977, I made additional qualitative collections in the lake's littoral zone by sweeping two $1.0 \mathrm{~m}^{2}$ quadrats in a Rupoia grass bed with a Turtox-Cambosco push net $(46 \mathrm{~cm} \mathrm{x}$ $20 \mathrm{~cm}$ ) and by making a visual search of the entire lake shoreline for cirripedes. In August, 1978, the USEPA also made qualitative invertebrate collections in the lake watershed. Using crustaceans as an indicator taxon, the species found in each of these three locations (i.e., Lake, Lake Watershed, and SR95I Canal), were used to detect faunal similarity between the three areas according to the method of Sorenson (1949):

$$
S=(2 C) /(A+B)
$$

where $A$ and $B$ represent the number of species in each community and $C$ represents the number of species common to both communities.

In an effort to define the seasonal changes in the benthic macroinvertebrate communities, bimonthly sampling was initiated during the period of intensive study (January December, 1978). A four stations transect was established in the eastern end of the lake (Figure 2), with 5 cores collected at each station on 3 February, 7 April, 6 June, 16 August, 10 October, and 6 December, 1978. The contents 
of each core were washed through a $0.701 \mathrm{~mm}$ sieve, and the retained fraction was then preserved in $10 \%$ formalin. After sorting, the specimens from each sample, were identified to the lowest possible taxa and counted. Subsamples of no less than 20 individuals of each species were dried for 24 hours at $105^{\circ} \mathrm{C}$ in a Grieve Model LR270C Laboratcry oven and then weighed on a Mettler H45 Balance to estimate biomass. In the results section which follows I will sumnarize the findings of ny research at Lake Marco Shores. 


\section{RESULTS}

\section{MORPHOMETRY}

The bathymetry of the lake ( $3 \mathrm{~m}$ contours) is depicted in Figure 12, and additional morphometric data are presented in Table 5. Wave action appears to have had minimal impacts on shoreline development. The slope of the basin above and below the water level were great ( $1: 1$ and $1: 1.5$, respectively) with rock outcrops and mangroves providing a great deal of stability to the beach. Hutchinson (1975a) has observed that such vertical cliffs rising from deep water tend to reflect waves virtually unchanged and, therefore, suffer virtually no wave erosion. Where shallower littoral shelf slopes were found such as on the northern, eastern, and western ends of the lake, submerged macrophytes (e.g.,

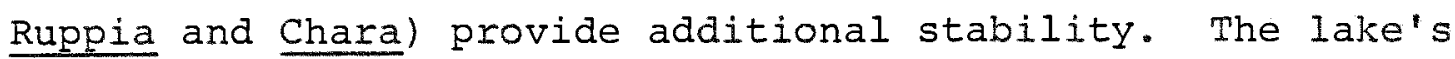
depth of cryptodepression is $7.5 \mathrm{~m}$. This means that $83 \%$ of the lake's volume is below mean sea level. This fact combined with the pervious nature of the soils will be later implicated as having had an impact on the physicochemical nature of the lake. 


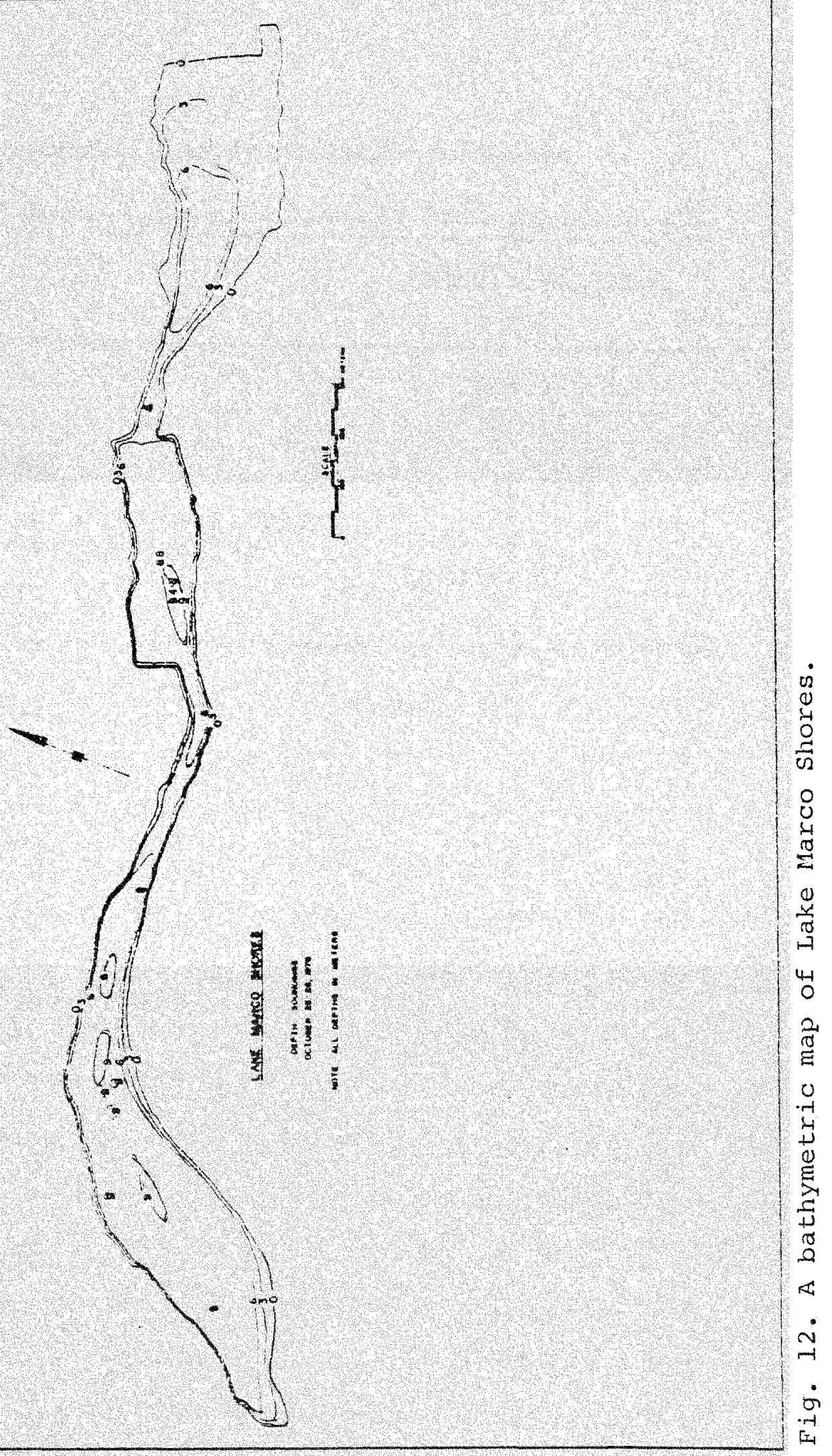


TABLE 5. Morphometric Data for Lake Marco Shores

Parameters

Calculated Value

Area (A)

Length (1)

Breadth (b)

Maximum depth ( $\mathrm{zm})$

Mean depth $(\mathrm{Zm})$

Average Elevation* of lake strface

Depth of crypto depression (ZC)

Volume (V)

$348.28 \mathrm{ha}$.

$3442.90 \mathrm{~m}$

$237.90 \mathrm{~m}$

$9.00 \mathrm{~m}$

$5.60 \mathrm{~m}$

$+1.50 \mathrm{~m}$

$7.50 \mathrm{~m}$

$1958089.60 \mathrm{~m}^{3}$

* NGVD 


\section{CLIMATE}

Although temperature records were continuous for the period of study (1978), daily values at 0800 have been extracted for presentation in Figure 13. Temperatures ranged from a low of $5^{\circ} \mathrm{C}$ in January to a high of $30^{\circ} \mathrm{C}$ in May, June, and July. Highly variable temperature patterns prevailed during the months of December, January, and February (span = $20^{\circ} \mathrm{C}$ ) as a result of the passage of winter storm fronts while the period May - September showed little variation $\left(\operatorname{span}=7^{\circ} \mathrm{C}\right)$. Average monthly air temperatures were not highly correlated $(r=0.62)$ with average monthly incident solar radiation which peaked in the April - May period and was at a minimum in December.

Figure 13 also includes monthly wind speed and direction roses. Wind percentages are concentrated upon eight points, and the arrows fly with the wind (NOAA,1978). The length of the arrow (see scale on Figure 13) gives the percent of the total number of monthly hours in which the wind blew from or near the given point. The number of feathers indicates the modal force of the wind in increments of $(<8 \mathrm{~km} / \mathrm{h}, 16-24 \mathrm{~km} / \mathrm{h}, 24-32 \mathrm{~km} / \mathrm{h}$, and $32 \mathrm{~km} / \mathrm{h})$. Numbers at the end of some arrows indicate the total number of hours each month that the wind speed exceeded $24 \mathrm{~km} / \mathrm{h}$. Although no data was available for January, February, and March, the dominant (20-50\%) wind direction for each of the 


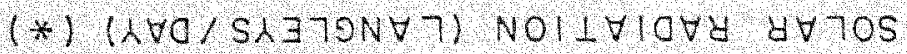

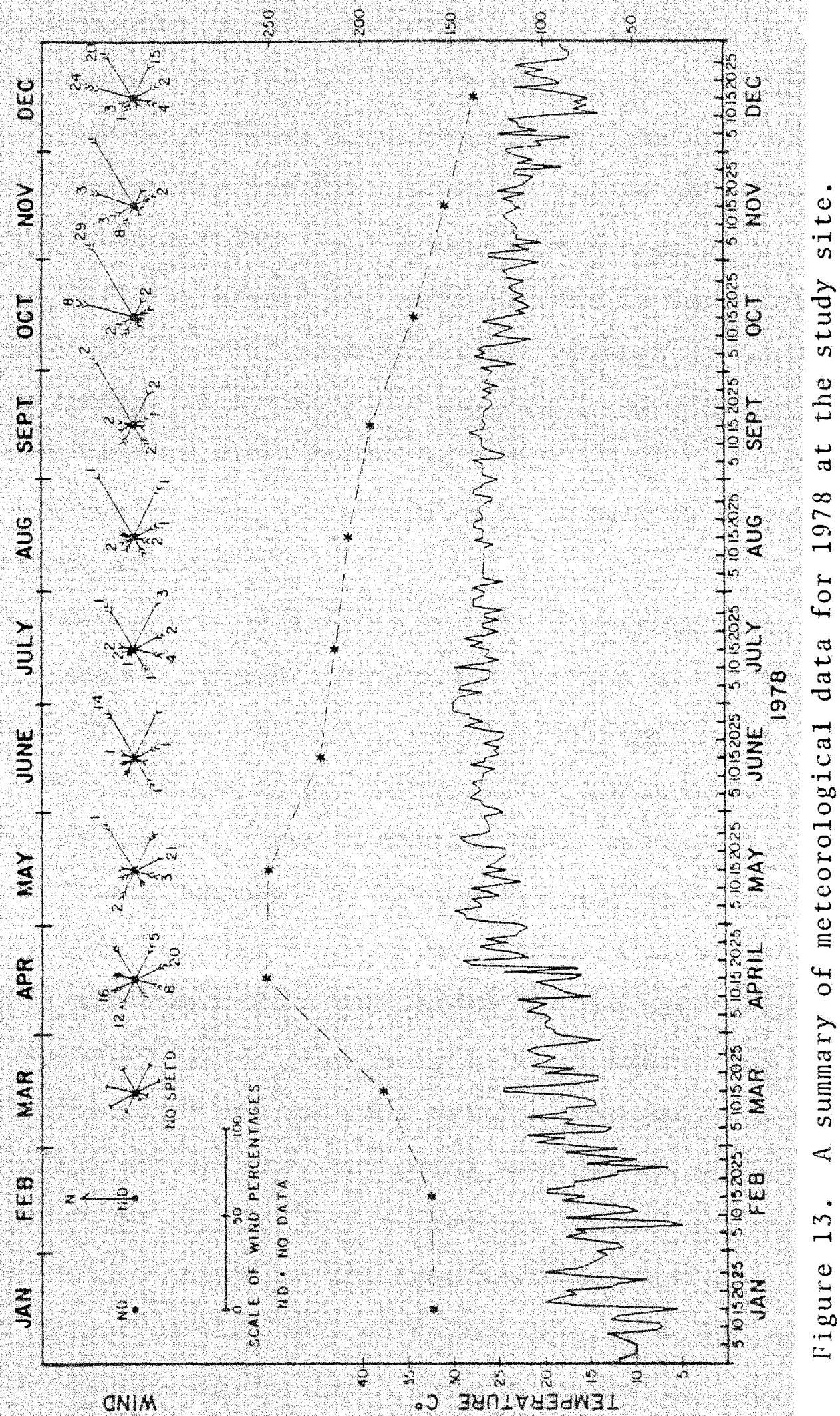


remaining months was from $045-067^{\circ}$. Wind from the $090-$ $112^{\circ}$ direction formed a seasonally significant fraction (40\%) of the directional percentage during the May - July period. During the October - November period 000-022 ${ }^{\circ}$ winds were also significant. Wind speeds were generally in the 16-24 km/h range, except for short periods in November (at directions of $155-180^{\circ}$ ) and due to the passage of the many frontal systems in December (at directions of 000-022\%). The least wind activity was evident during July - September while highest speeds $(24$ to $>32 \mathrm{~km} / \mathrm{h})$ were most frequent in December and April.

A thirty year (1940-1970) record of precipitation at The U.S. Weather Bureau's Page Field Station in Ft. Myers indicates an annual average rainfall of $135 \mathrm{~cm}$ for the study area (Reynolds et al. 1979). When the monthly records for 1978 at the two sites bracketing Lake Marco Shores (Figure 14) are compared to these data, they indicate a below average rainfall ( $20.0 \mathrm{~cm}$ ). This is also true if 1978 data are compared to the record for the previous five years at the two sites (Figure 15). Furthermore, the coastal site has a net rainfall deficit when compared to the mainland site. These phenomena have also been observed by Weinstein et al. (1977) for previous years. The historical rainfall pattern for the area has generally been bimodal in nature with July being the wettest month and March the driest (Figure 15). In 1978, there was less than 


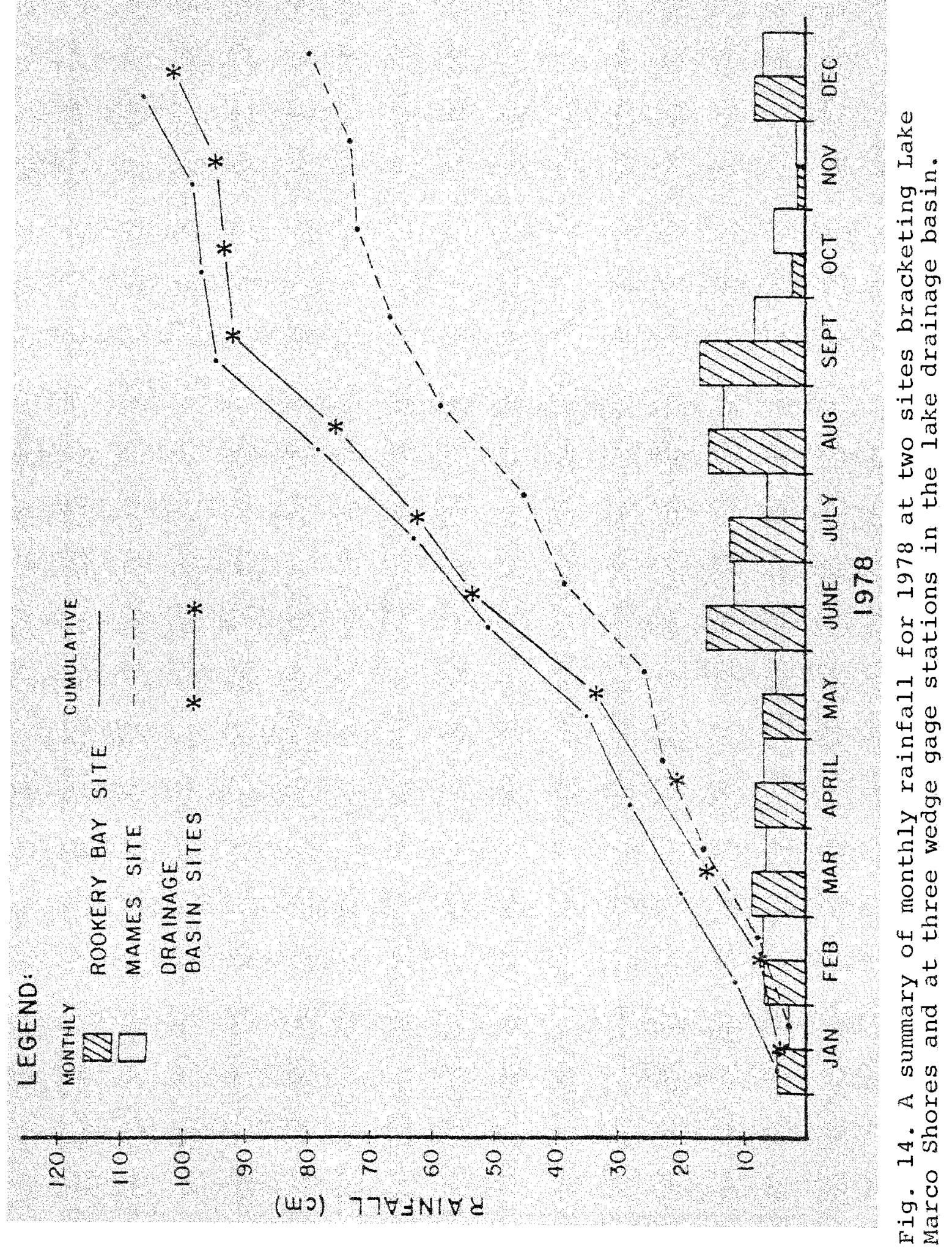




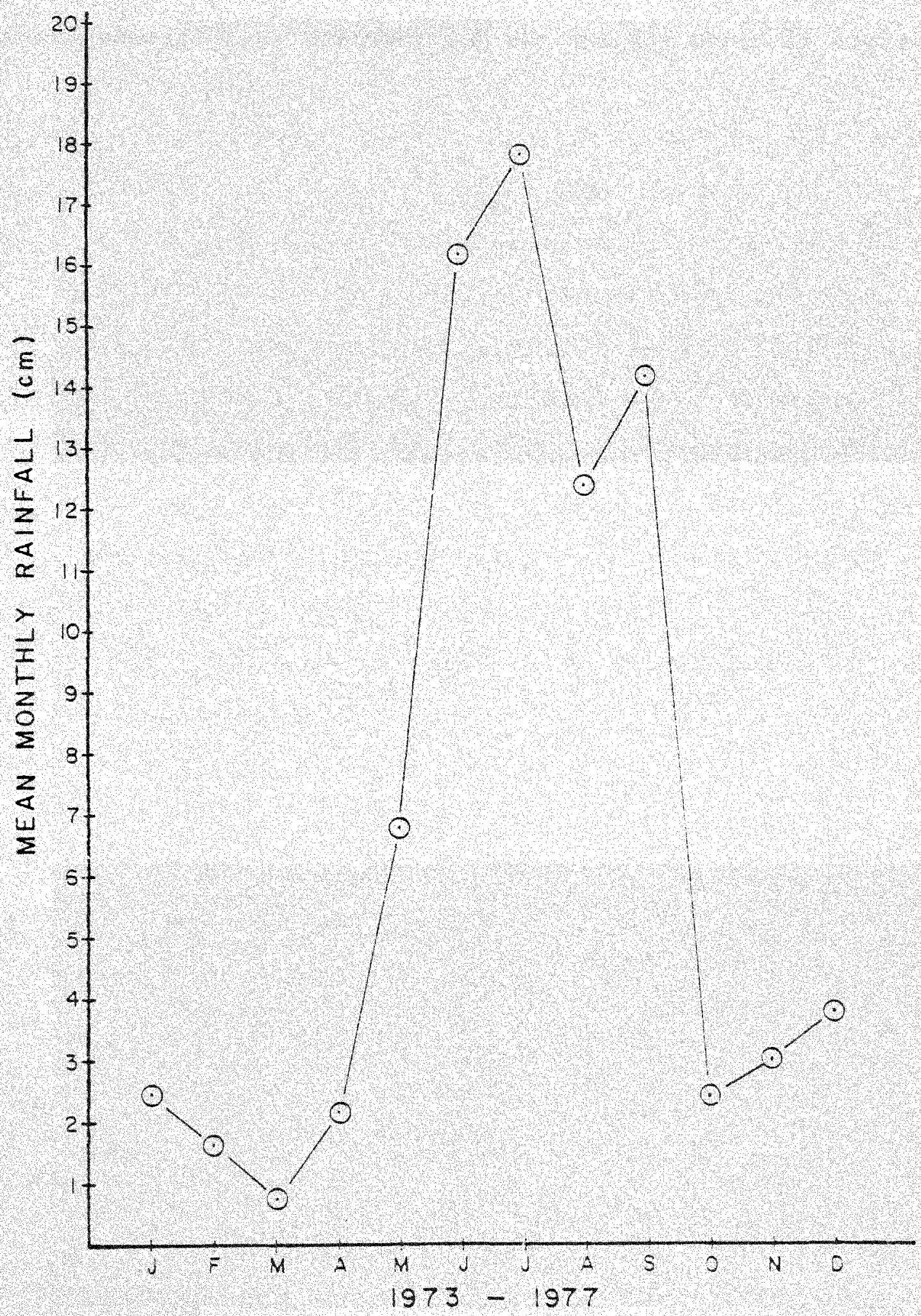

Fig. 15. Mean monthly rainfall for the period 1973-1977. 
average variation in rainfall between months with the driest month occurring in November and the wettest month in August. 


\section{LAKE SEDIMENTS}

The sedimental analysis revealed an organic composition ranging from $0.01 \%$ in the silt and clay fraction (less than $88 \mu \mathrm{m})$ to $4.4 \%$ in the coarse sand fraction $(500 \mu \mathrm{m})$ with most of the organic material occurring at depths of greater than $1.0 \mathrm{~m}$. The mode for inorganic material was in the Fine-Medium Sand fractions (149 $\mu \mathrm{m}$ or $297 \mu \mathrm{m}$ ) at all depths except at 1.5 meters, and at 2.1 and 3.0 meters. The silt and clay fraction was increasingly dominant at levels below the chemocline. x-ray diffractional analyses of sediments from the deepest part of the lake (>9.0 m) indicated that the major constituent of this fine material was magnesium calcite (Dr. James Charlesworth - personal cormunication. 


\section{HYDROMECHANICS}

Theoretical maximum wave heights $(0.3 \mathrm{~m}$ and $0.46 \mathrm{~m}$ ) for the longest fetch distances $(944 \mathrm{~m}$ and $881 \mathrm{~m}$, respectively) were never approached during periods of maximum wind $(60 \mathrm{~km} / \mathrm{h})$ at the lake. Observed wave heights in fact only ranged from zero to $0.24 \mathrm{~m}$ for the forty observations, and the most frequent observation was of a rippled or becalmed lake surface. As has been noted, the highest intensity winds usually occurred over short periods and were generally not in the direction of the longer fetch distances at the lake (i.e. $040^{\circ}, 059^{\circ}, 086^{\circ}$, and their reciprocals).

Regression of total hours of wind in excess of $24 \mathrm{~km} / \mathrm{h}$ for the seven days prior to mixolimnionic salinity measurements (and from the directions corresponding to each of the longer fetch distances) versus average mixolimnionic salinity did not produce a significant correlation $(r=0.20)$. This was also true for the regression of rainfall on salinity $(r=0.09)$. 
HYDROLOGY

The tidal record at MacIlvane Bay is compared to the elevation of Lake Marco Shores for the month of January, 1977 in Figure 16. The record for the lake is sensitive enough to show long term water loss before and after a $7.9 \mathrm{~cm}$ rain on 15 January. Van de Kreeke (University of Miami - personal communication) has analyzed several months simultaneous water level data from gages at these two locations and found no tidal penetration of the lake.

Water level hydrographs for each of the staffs in the lake and in the surrounding watershed during the period of intensive study are shown in Figure 17 along with mean rainfall records for all (4) of the wedge rain gages. Minimum water elevations occurred during the month of April as a result of the effects of the previous dry season while maximum water levels occurred in the August-September period at the end of the rainy season.

Staff 2 which was located in a saltern between adjacent pinelands uplands and cordgrass wetlands (Figure 1) indicated standing water for only a short period at the end of the wet season. Water levels at this station did not fluctuate in consonance with those measured by the remaining staffs. Staffs 3 and 4 located in Lake Marco Shores showed good agreement in water level elevations and fluctuations between the eastern and western ends of the lake, respectively. 


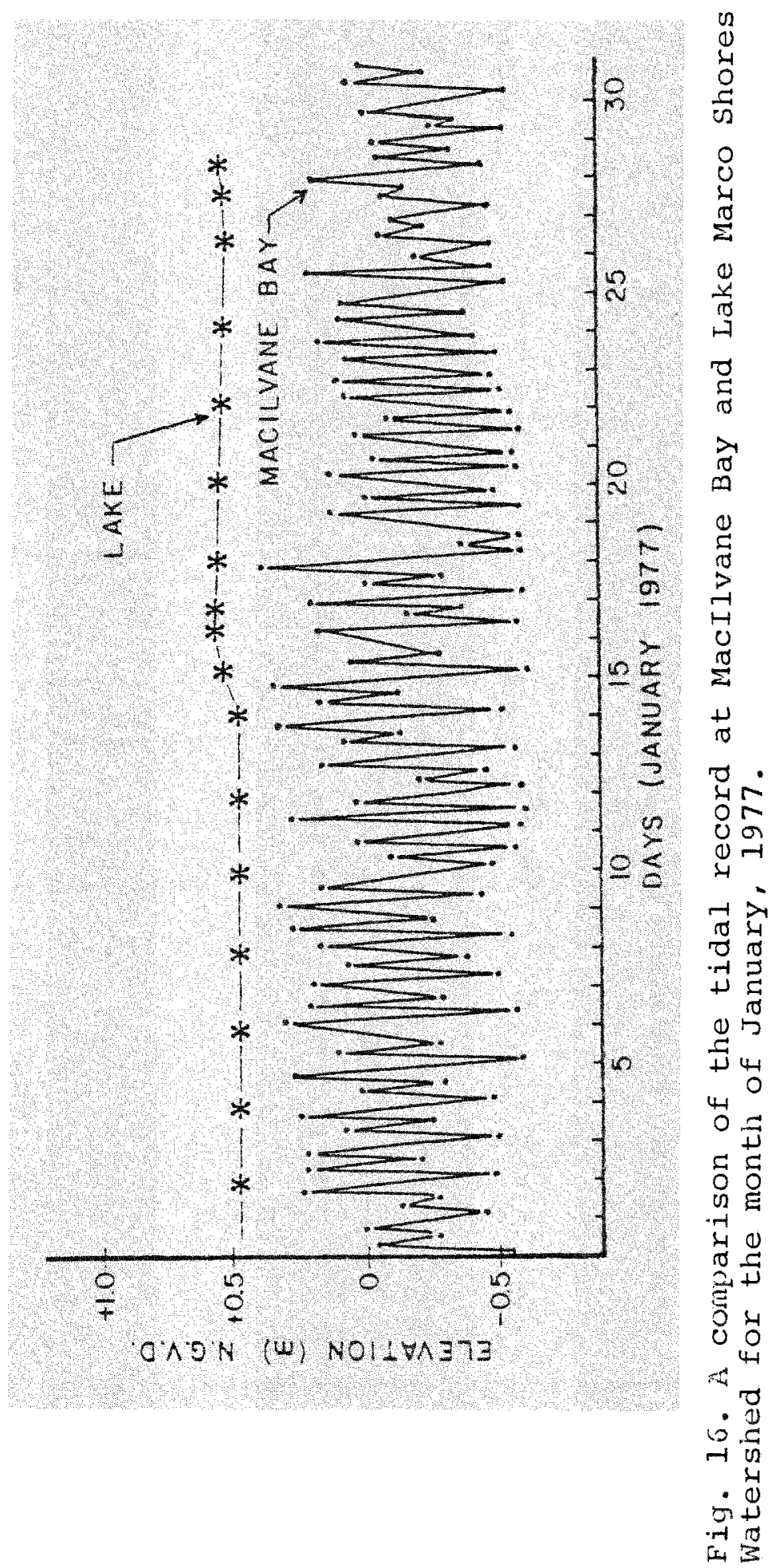




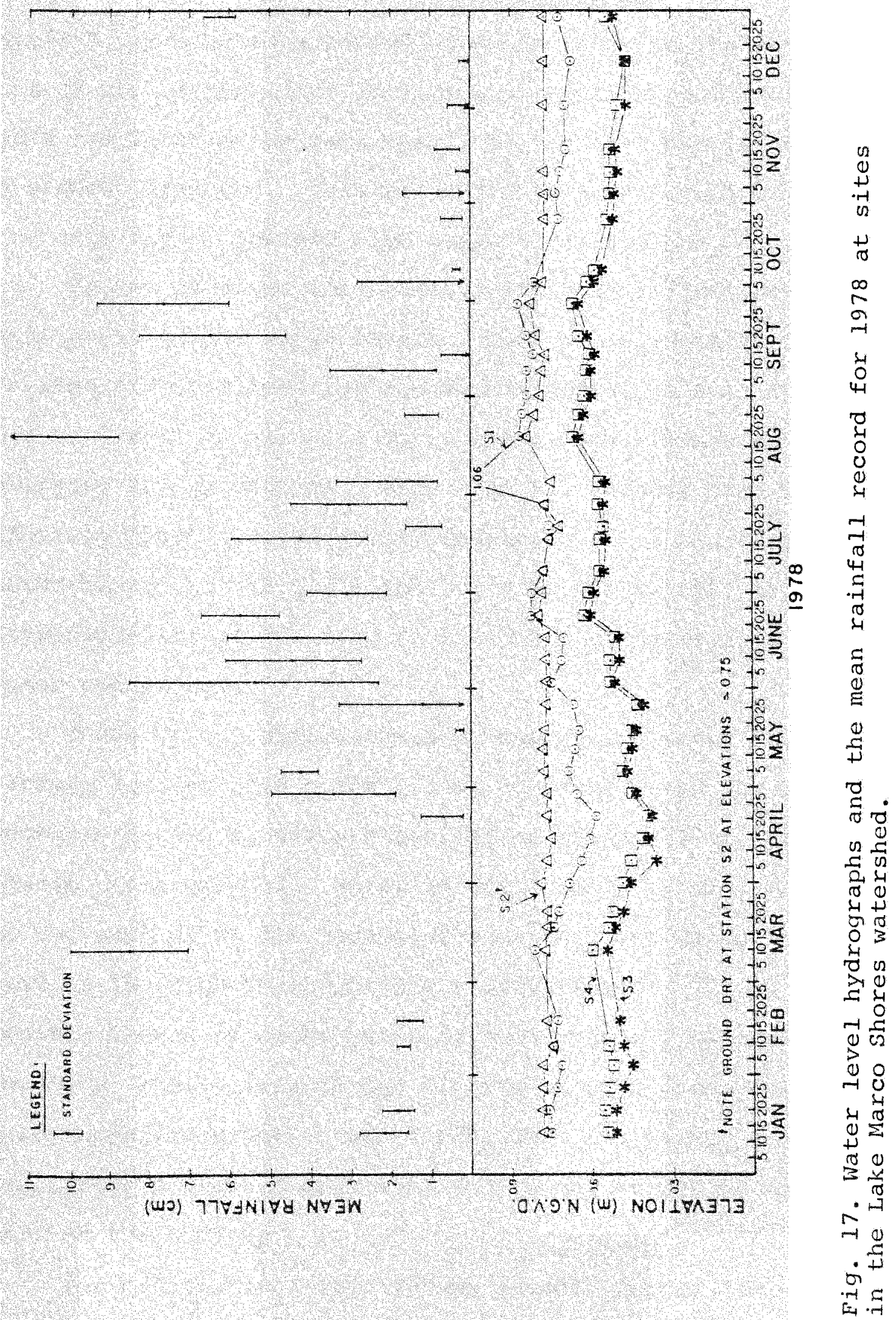


Staff 1, located in a borrow ditch adjacent to the eastern end of the airport dike (Figure 1), responded to water gain and loss in the same manner as the lake staffs, but at a higher elevation. This may indicate a surveying error or the site may be perched with respect to the lake.

Figure 18 shows the relationship that existed between well point ground water levels. Mean monthly aquifer elevations are displayed for comparable depths $10.6 \mathrm{~m}, 1.2 \mathrm{~m}$, $5.3 \mathrm{~m}, 8.4 \mathrm{~m}$ ) at all well sites along with average monthly chloride concentrations. Site 1 on the airport dike was elevated above natural ground levels by $\sim 2.0 \mathrm{~m}$ making the measurements at the $0.6 \mathrm{~m}$ and $1.2 \mathrm{~m}$ depths at this site representative of the dike fill and not of prevailing ground water conditions.

There was a general trend of decreasing water in the surface aquifer $(0.6 \mathrm{~m}$ and $1.2 \mathrm{~m})$ at site 2 over the OctoberDecember period as surface aquifer water levels in this impounded area dropped. Water levels at well sites 4 and 5 to the west of SR 951 were always below those sites to the east of the highway indicating a difference $(\sim 0.2 \mathrm{~m})$ in aquifer levels on either side of the highway. Chloride levels at these sites ( 4 and 5 ) were at or above normal seawater concentrations at all depths over the period of study indicating a greater degree of salt water intrusion to the east of the highway.

Table 6 includes the average monthly values for selected 


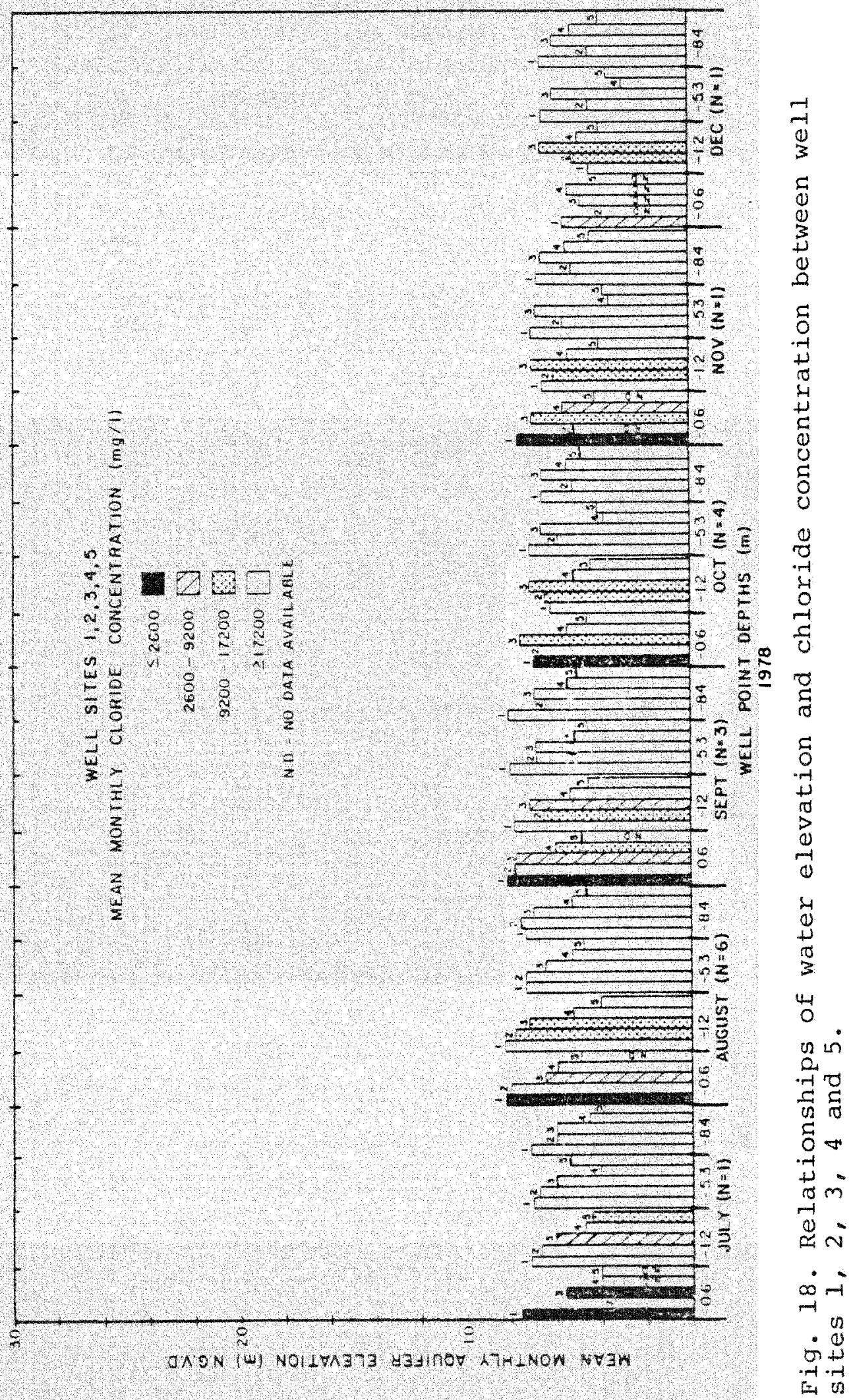




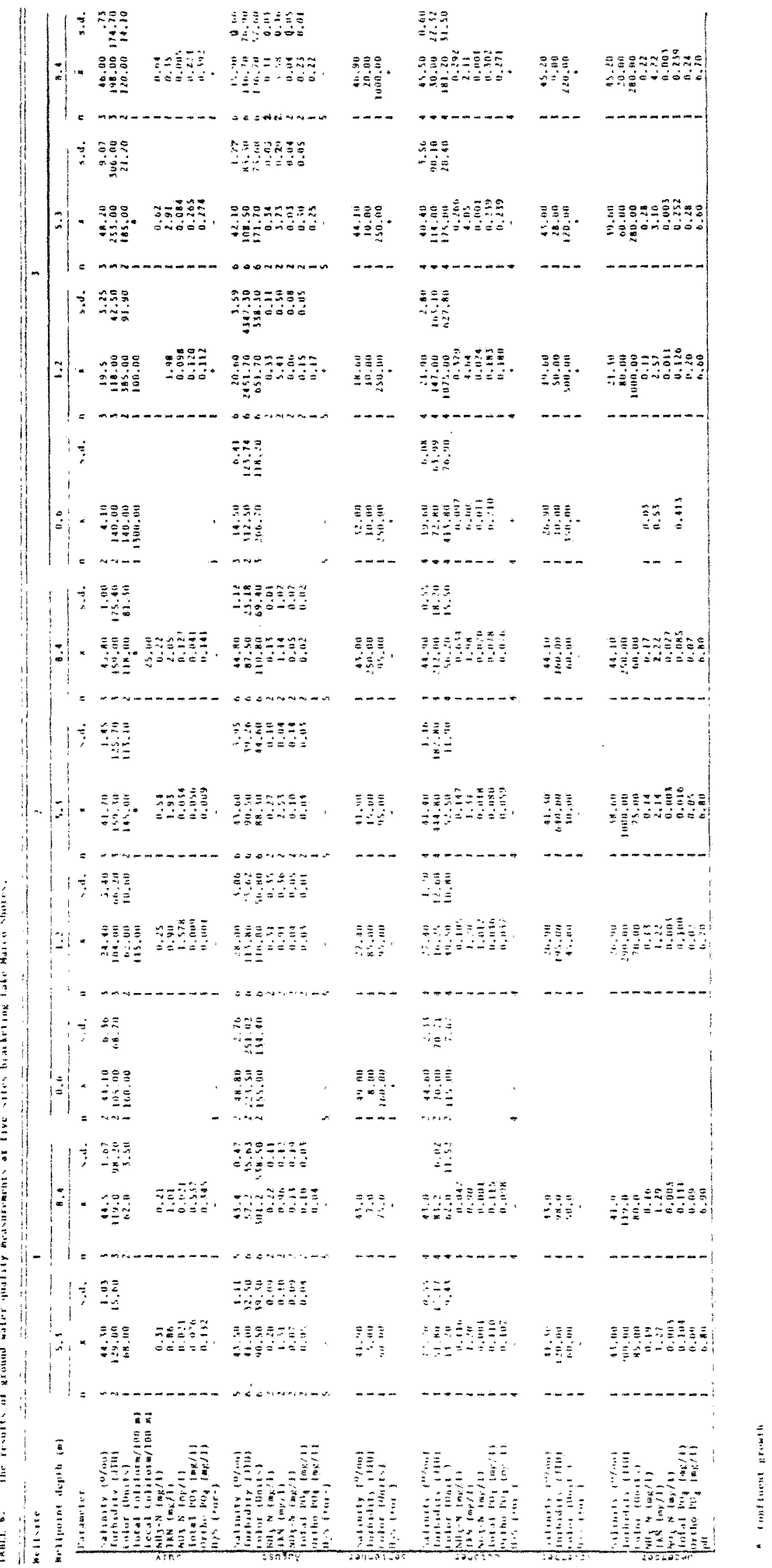


parameters at all well points excluding the shallow levels at site 1 and all of the levels at sites 4 and 5 .

The chemical data generally indicated that the same type of hypersaline water which occurred below the chemocline in the lake was typical of ground water in the area surrounding the lake. Salinities from the two deepest well points were always hypersaline. The surface aquifer on the other hand was usually brackish ranging from $4.1 \%$ shallowest depth at site 3 to $49.0 \%$ at the shallowest depth at site 2 . The results at site 2 indicated that a hypersaline surface layer was above a brackish water zone. Anmonia-nitrogen was generally highest in samples from the deeper well points Kjeldahl nitrogen levels showed no trend with depth or season. Total phosphate and orthophosphates were always highest in samples from the deeper aquifer. Hydrogen sulfide was most frequently observed in samples from site 3 located nearest to tidal waters, and the water from this site was always more colored than that from any of the other sites. All wells showed slightly acidic pHs (range $6.6-6.9)$.

Summaries of the results of the ground water seepage experiments are presented in Table 7. Additional measurements from canals bordering the drainage area are presented in Table 8. The data suggest that water from the fresh $(0.8-5.2 \%$ surface aquifer moved into the lake through the northern littoral zone at an average rate of $\sim 192 \mathrm{ml} /$ 


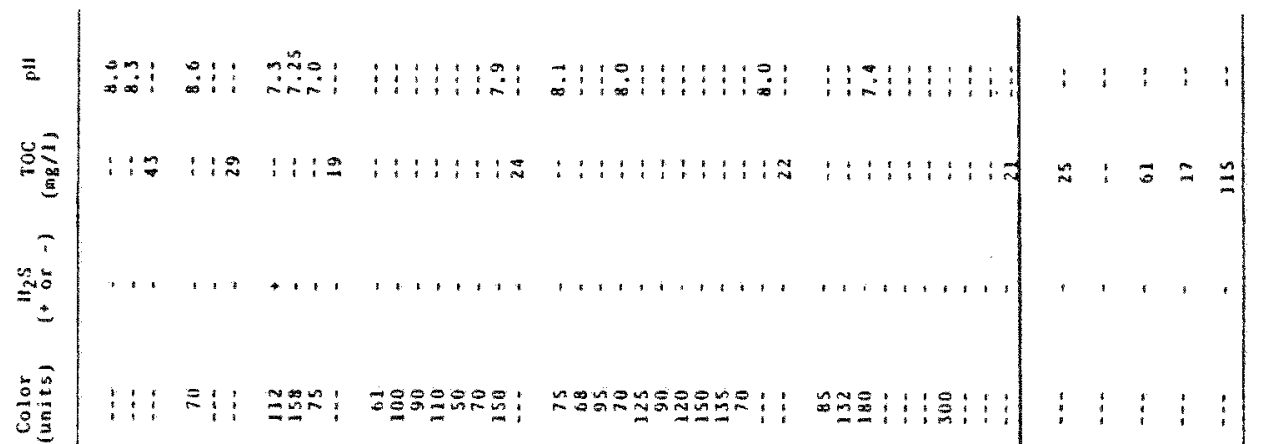

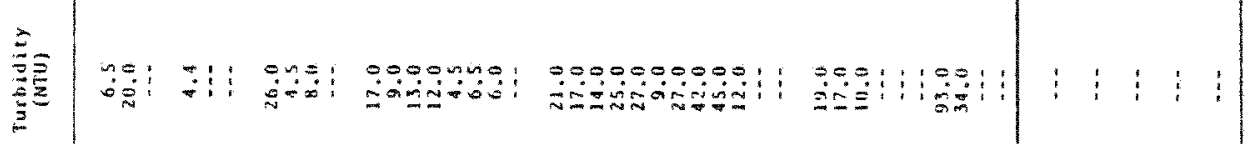

高等

运

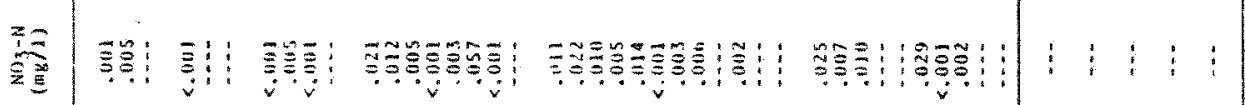

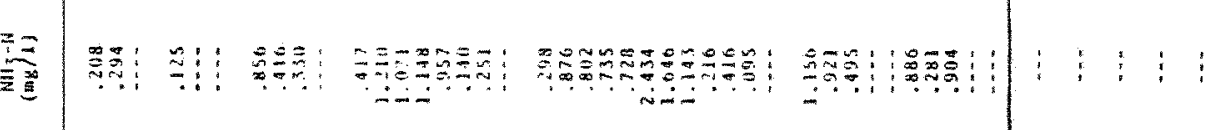

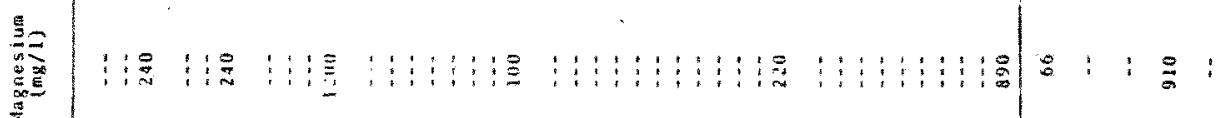

窇焉

苞是

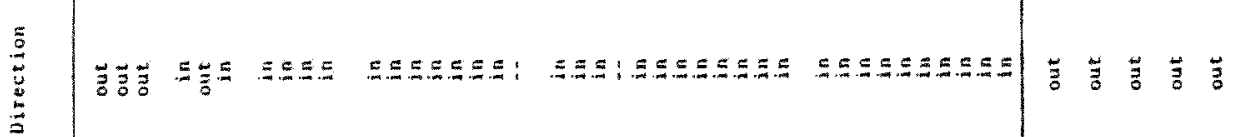

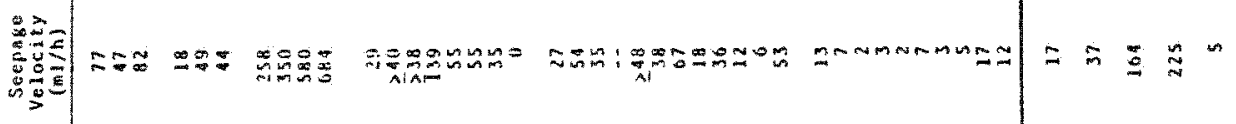

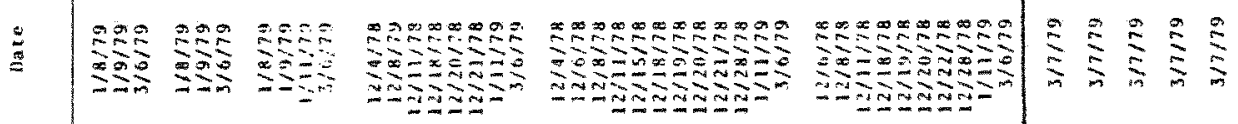

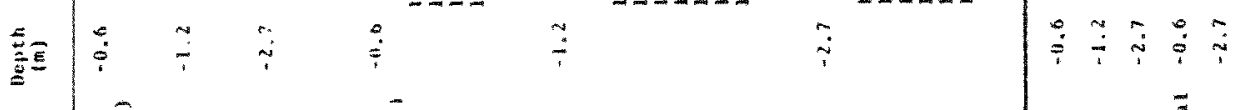

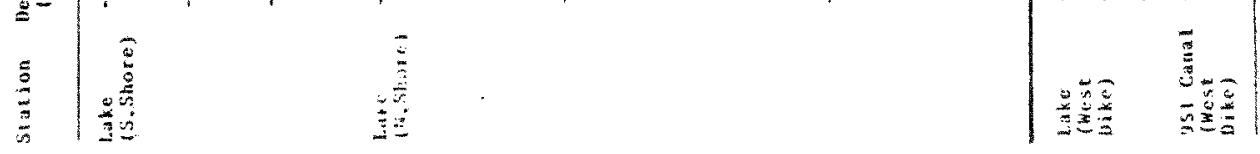




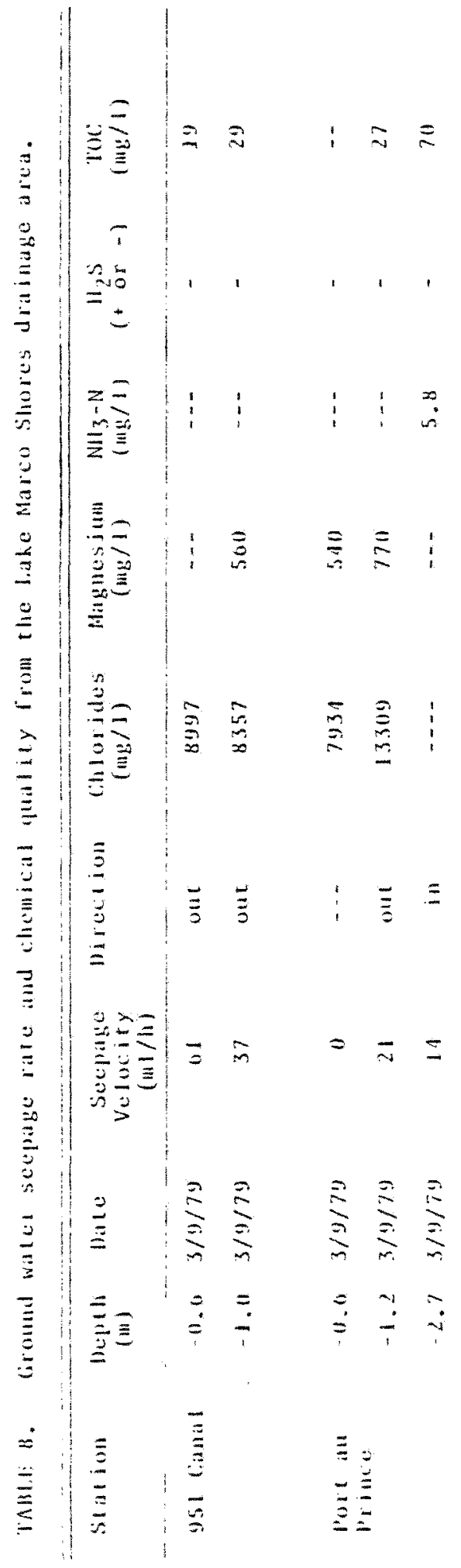


$\mathrm{h} / \mathrm{m}^{2}$ (mode $55 \mathrm{ml} / \mathrm{h}$ ) and that lake mixolimnionic water exited through the south littoral zone at an average rate of $\sim 251$ $\mathrm{mI} / \mathrm{h} / \mathrm{m}^{2}$ and through the dike by the SR 951 canal at an average of $105 \mathrm{ml} / \mathrm{h} / \mathrm{m}^{2}$. Counter flow was evident at deeper stations $(-2.7 \mathrm{~m})$ with saline $(17.4-24.4 \%$ ground water entering through the southern littoral zone at an average rate of $1835 \mathrm{ml} / \mathrm{h} / \mathrm{m}^{2}$ and exiting through the dike at an average rate of $451 \mathrm{ml} / \mathrm{h} / \mathrm{m}^{2}$. Measurements of groundwater seepage from the drainage area indicated average rates of surface aquifer discharge to the SR 951 canal of $\sim 192$ $\mathrm{ml} / \mathrm{h} / \mathrm{m}^{2}$ and to the Port au Prince canal system of $\sim 39 \mathrm{ml} /$ $\mathrm{h} / \mathrm{m}^{2}$. The seepage data were highly variable and are therefore presented only to suggest trends. Insufficient data were collected to construct a ground water balance equation. Whereas a high degree of variation was evident in flow rate data at a given station, chemical data were less variable. Surface aquifer water quality was characterized by low chloride levels (range $1796-3703 \mathrm{mg} / 1$ ), low nitratenitrogen $(0.001-0.057 \mathrm{mg} / 1)$, low total phosphate $(0.008-$ $0.213 \mathrm{mg} / \mathrm{l}$ ) and no hydrogen sulfide but high ammonia-nitrogen $(0.095-2.434 \mathrm{mg} / 1)$, total kjeldahl nitrogen (1.57-5.24 $\mathrm{mg} / 1$ ) and $\mathrm{pH}(7 \cdot 9-8.1)$. Deeper, saline, ground water on the other hand was characterized by high chlorides (7659-24162 $\mathrm{mg} / 1)$, total phosphate $(0.048-0.541 \mathrm{mg} / 1)$, ammonia-nitrogen (0.281-1.156 mg/1) and coler (85-300 units), but low nitrate-nitrogen $(0.281-1.156)$ and $\mathrm{pH}$ (7.4). 
Ionic magnesium ( $\mathrm{Mg}$ ) is found at an average concentration of $1155 \mathrm{mg} / \mathrm{l}$ in oceanic waters while chlorides (Cl) average approximately $17200 \mathrm{mg} / 1$ (Sverdrup et al. 1942). While dilution or concentration of sea water may occur, the ratio between such conservative ions would not be expected to vary substantially. The $\mathrm{Mg}: \mathrm{Cl}$ ratio for sea water is 0.067 , and virtually all samples of water leaving the lake were close to this ratio (range .056 - .076). Exceptions were found for water entering the lake from the north surface aquifer which contained low magnesium relative to chloride (ratio $=.027$ ) and for surface waters that left the lake by seeping through the western dike (ratios $=0.021$ to 0.244$)$. 
OPTICAL AND THERMAL PROPERTIES

Secchi disk transparencies for Station WQ4 at Lake Marco Shores for the period January - December, 1978, are shown in Figure 19. Secchi depths ranged over a small interval for the year $(1.37 \mathrm{~m}-2.44 \mathrm{~m})$, and averaged $1.89 \mathrm{~m}$ $(n=38 ; s . d .=0.31 \mathrm{~m})$ although there was a general trend toward decreased transparency during the April - September rainy season. On 8 occasions (six of which were during the dry season) secchi depths corresponded with the depth of the top of the chemocline. Secchi depths never exceeded the depth of the bottom of the chemocline.

Temperature profiles at Station WQ 4 for the periods January - June, and July - December, are presented in Figures 20 and 21, respectively. Each monthly value represents an average of from 2-4 "weekly" measurements. Lake Marco Shores was homiothermic below a depth of $4.0 \mathrm{~m}$ for the entire year with monimolimnionic waters only ranging from $25.0-26.5^{\circ} \mathrm{C}$. This temperature interval coincided with the average maximum summer air temperatures (Figure 13). A wide variety of vertical profiles were exhibited over the annual cycle as the mixolimnion followed the seasonal pattern of air temperatures (Figures 13, 20, and 21). In the November - March period, the mixolimnion was from 15 - 40 percent colder than the monimolimnion. Then after the lake as a whole approached homiothermy in April, the mixolimnion 


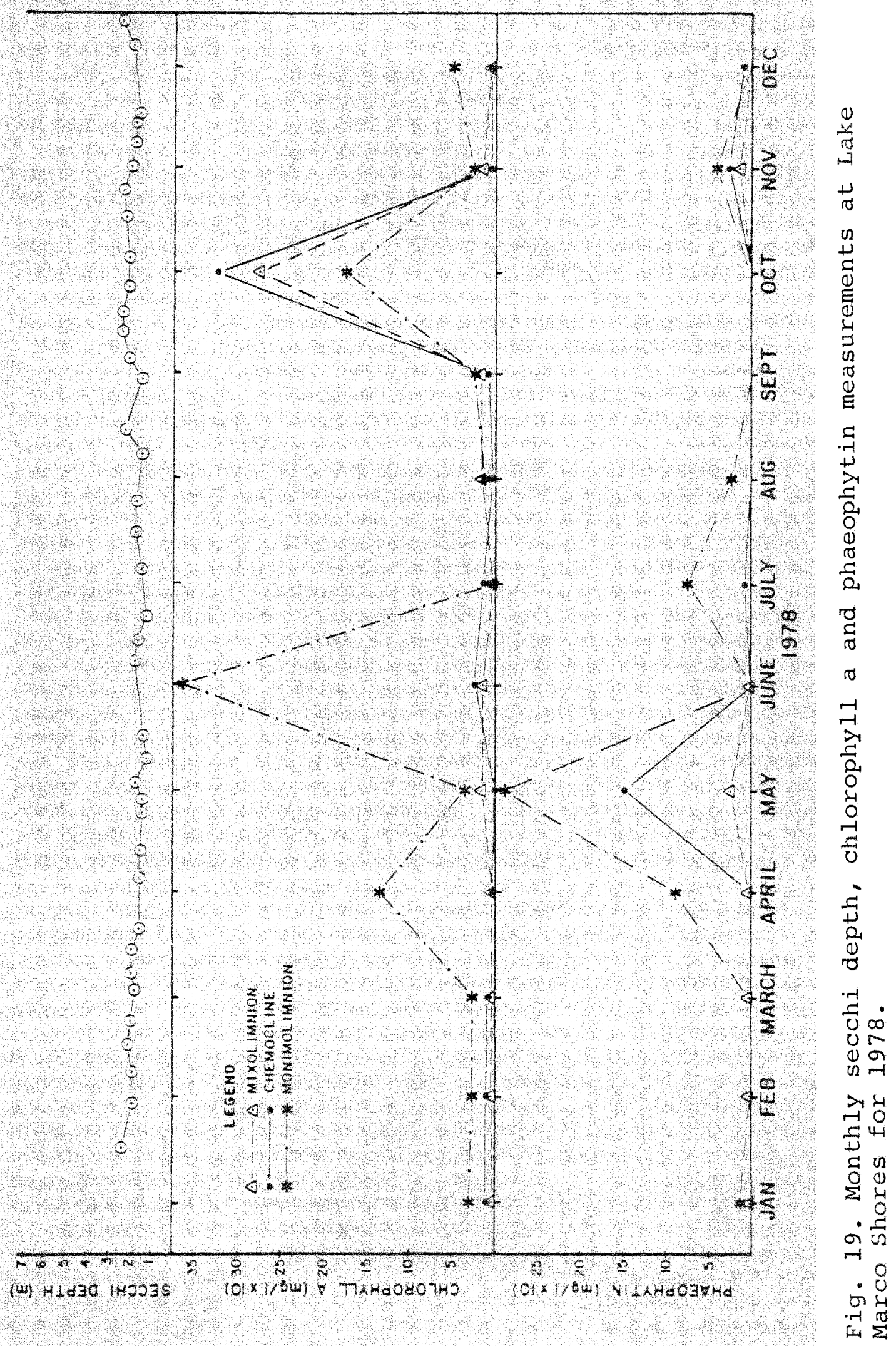




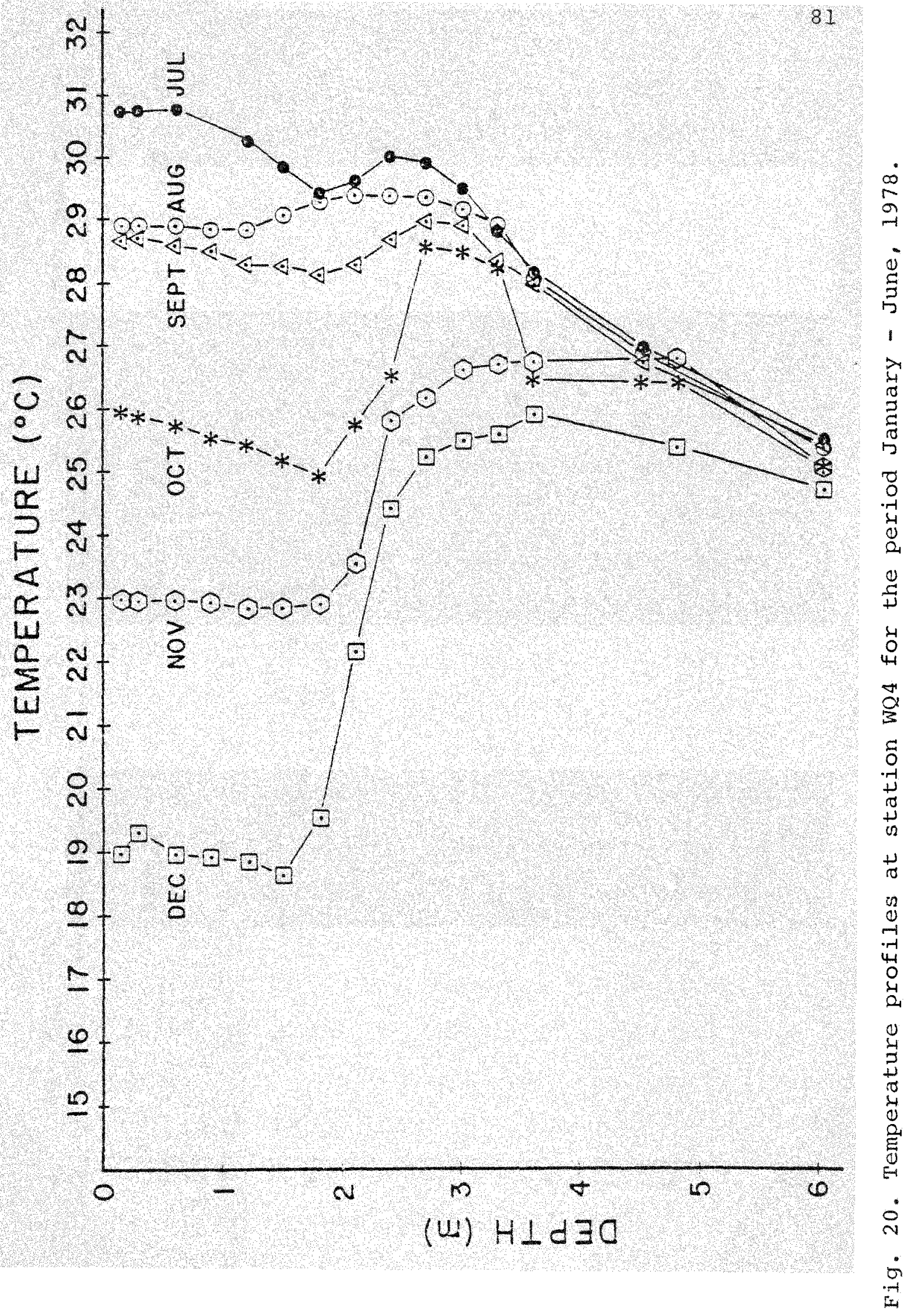




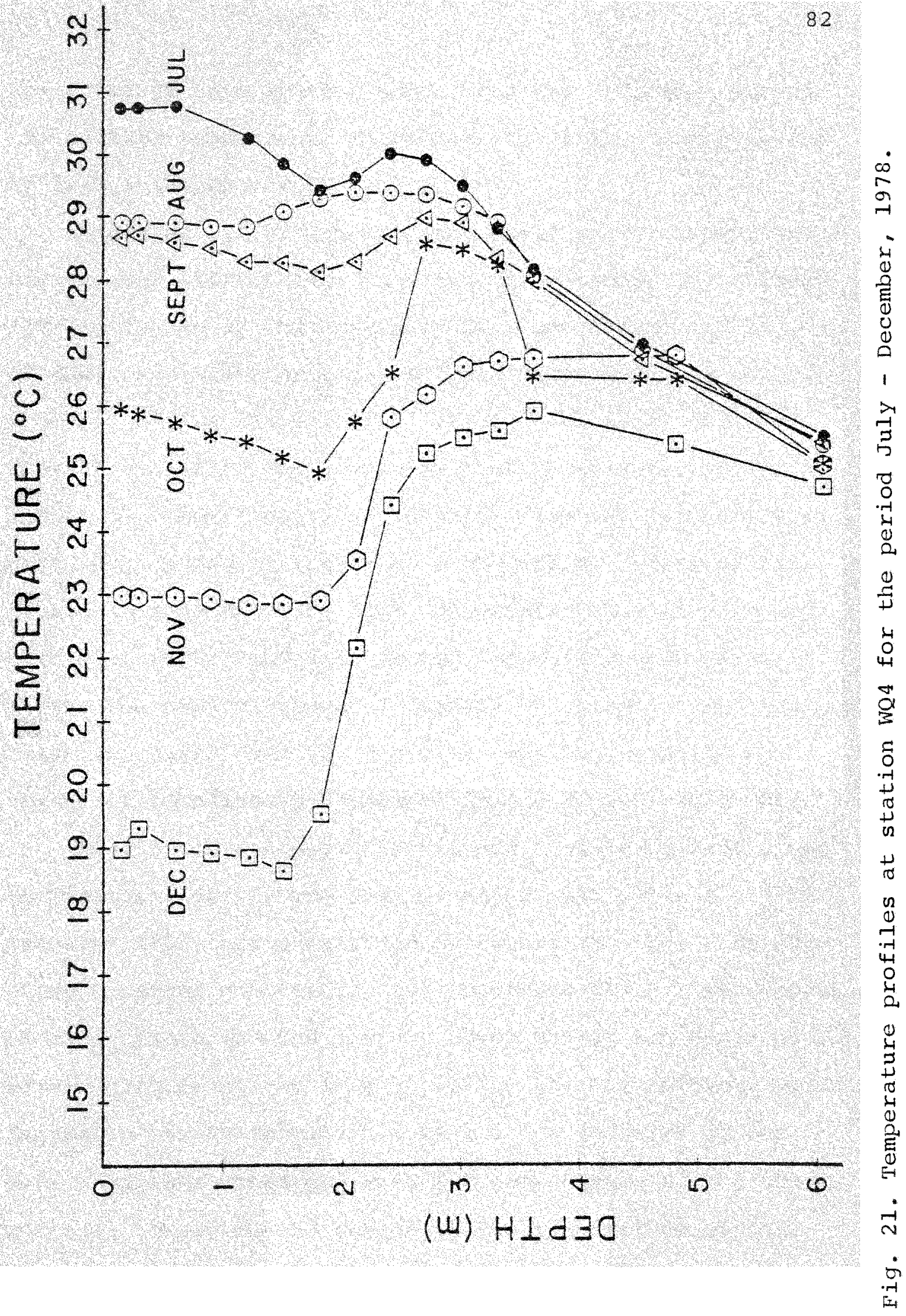


continued to warm so that during the May - october period its average temperature exceeded that of the monimolimnion by from 1-18 percent.

Anomalous poikilothermic and mesothermic temperature curves were evident from June through October. Hutchinson (1975a) has noted that extraordinary mesothermy can be produced by a shallow zone of fresh water lying on top of a highly saline lower layer. This "greenhouse" received heat by radiation but lost none none by evaporation and little by convection. The data for June and october, were particularly demonstrative of a chemocline heated by radiation to a temperature that was greater than either mixolimnionic waters above or monimolimnionic waters below it. During the period October - January the slope of the thermocline decreased from 0.31 to 0.13 , but beginning in February, it immediately increased from 0.31 to 1.58 in May. Results of a 24 hour continuous profile of lake water temperatures during the unprecidented cold spell of 19-21 January, 1977, are sumnarized in Figure 22. The data provided a unique opportunity for observing the maximum degree of temperature induced mixing. Even though air temperatures were depressed at the lake to $2.2^{\circ} \mathrm{C}$, the only effects manifested in the water column were a $3.0^{\circ} \mathrm{C}$ decrease of the $0.15 \mathrm{~m}$ surface water and a slight compression of the thermocline. There was no change in the temperature of the monimolimnion. 

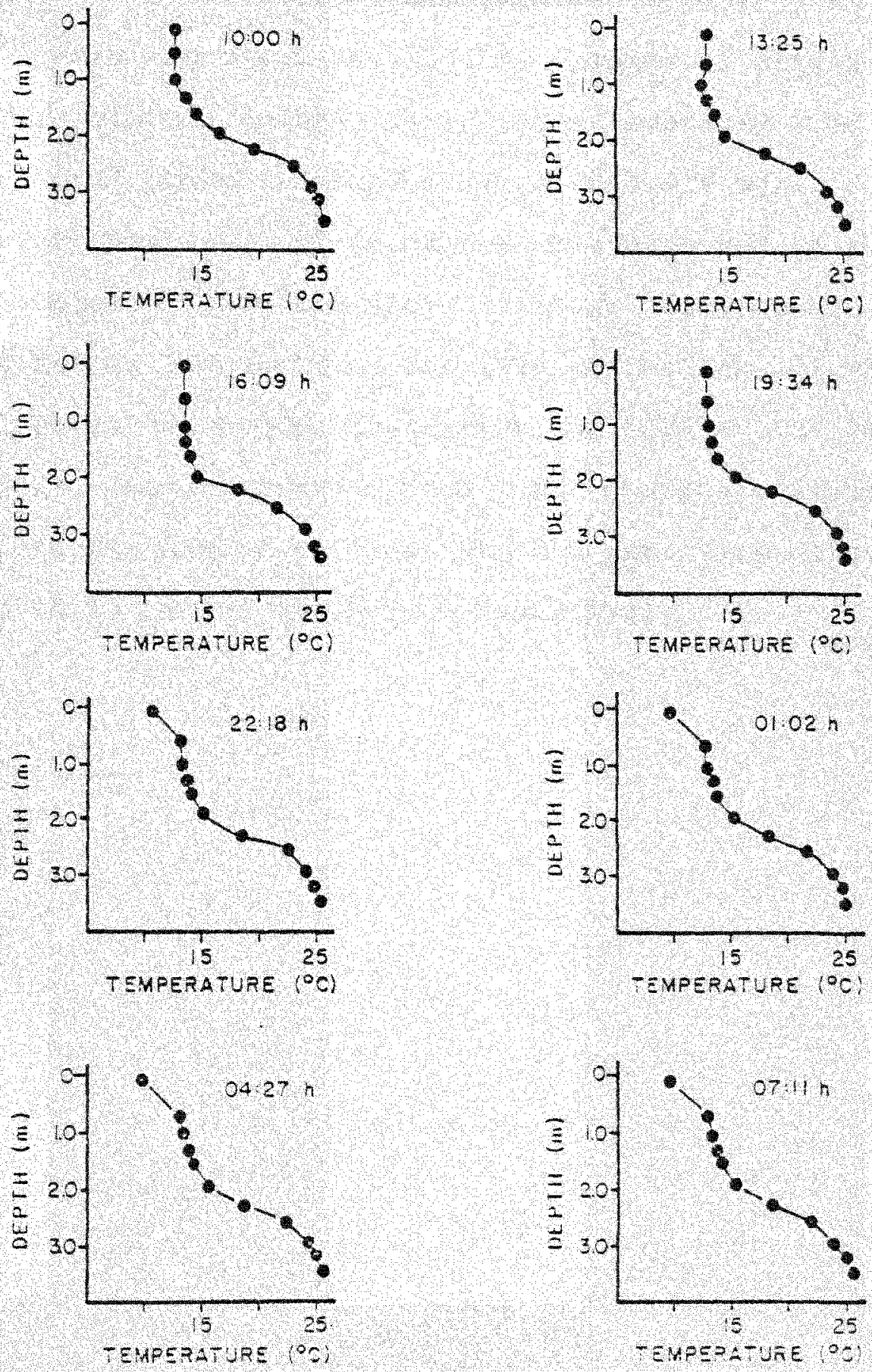

Fig. 22. Results of a 24 hour continuous profile of lake water temperatures during the period 19-21 January, 1977. 
WATER QUALITY

Rainfall. The results of analyses of three separate rainfall events are given in Table 9. Inputs of nitrate-nitrogen via rainfall to Lake Marco Shores averaged $0.168 \mathrm{mg} / 1$ while total phosphate inputs averaged $0.028 \mathrm{mg} / 1$. Insignificant quantities of chlorides were measured in two of the samples. Using the above "average" concentrations and total rainfall quantities for 1978 at the lake $(1.03 \mathrm{~m})$, total nitrate-nitrogen quantities for 1978 at the lake $(1.03 \mathrm{~m})$, total nitrate-nitrogen and phosphate inputs to the lake via direct rainfall for the year were calculated to be $60.27 \mathrm{~kg}$ and $10.04 \mathrm{~kg}$, respectively. 
TABLE 9. The Water Quality of three rainfall events at Marco Island, Florida.

\begin{tabular}{lccc}
\hline Date & $\mathrm{NO}_{3}-\mathrm{N}(\mathrm{mg} / 1)$ & $\mathrm{T}-\mathrm{PO}_{4}(\mathrm{mg} / \mathrm{I})$ & $\mathrm{Cl}-(\mathrm{mg} / \mathrm{I})$ \\
\hline $5 / 31 / 78$ & 0.174 & 0.020 & --0 \\
$7 / 11 / 78$ & 0.089 & 0.032 & 1.0 \\
$8 / 08 / 78$ & 0.241 & 0.031 & 1.0 \\
\hline
\end{tabular}


Dissolved gasses. Figures 23 and 24 depict the monthly averages of from 2-4 "weekly" measurements of dissolved oxygen at Station WQ4 during 1978. With the exception of a slight elevation of the chemocline in August the profiles were remarkably uniform over the period and showed a nearly saturated mixolimnion to a depth of $\sim 2.0 \mathrm{~m}$. There was a rapid rate of oxygen decrease across the chemocline $12.0 \mathrm{~m}-$ $2.5 \mathrm{~m}$ ) with no oxygen below the $3.7 \mathrm{~m}$ depth (the indication of measurable oxygen below this depth during February was assumed to have been a sampling error resulting from improper meter calibration). This stability was evident throughout the coldest, windiest and rainiest months (January, December, and september, respectively). A hydrogen sulfide odor was always noticed whenever pumped samples from the monimolimnion were collected. Additional pH profile measurements for 12 November, 1976 and 13 March, 1979 (Figure 25), indicated that free carbon dioxide was undoubtedly also available in the monimolimnion. Hydrogen ion concentrations for the 13 March samples were highest (8.45-8.70) in the lower mixolimnion and top of the chemocline and lowest $(6.8-7.3)$ in the monimolimnion. The upper mixolimnionic waters $(0.2 \mathrm{~m}-0.9 \mathrm{~m})$ were of generally high $\mathrm{pH}(8.05-8.20)$. The observed difference in $\mathrm{pH}$ between the $2.1 \mathrm{~m}$ depth $(\mathrm{pH} 8.7)$ and the $2.4 \mathrm{~m}$ depth $(\mathrm{pH} 7.3)$ provided further evidence of the stable configuration of the water column. 


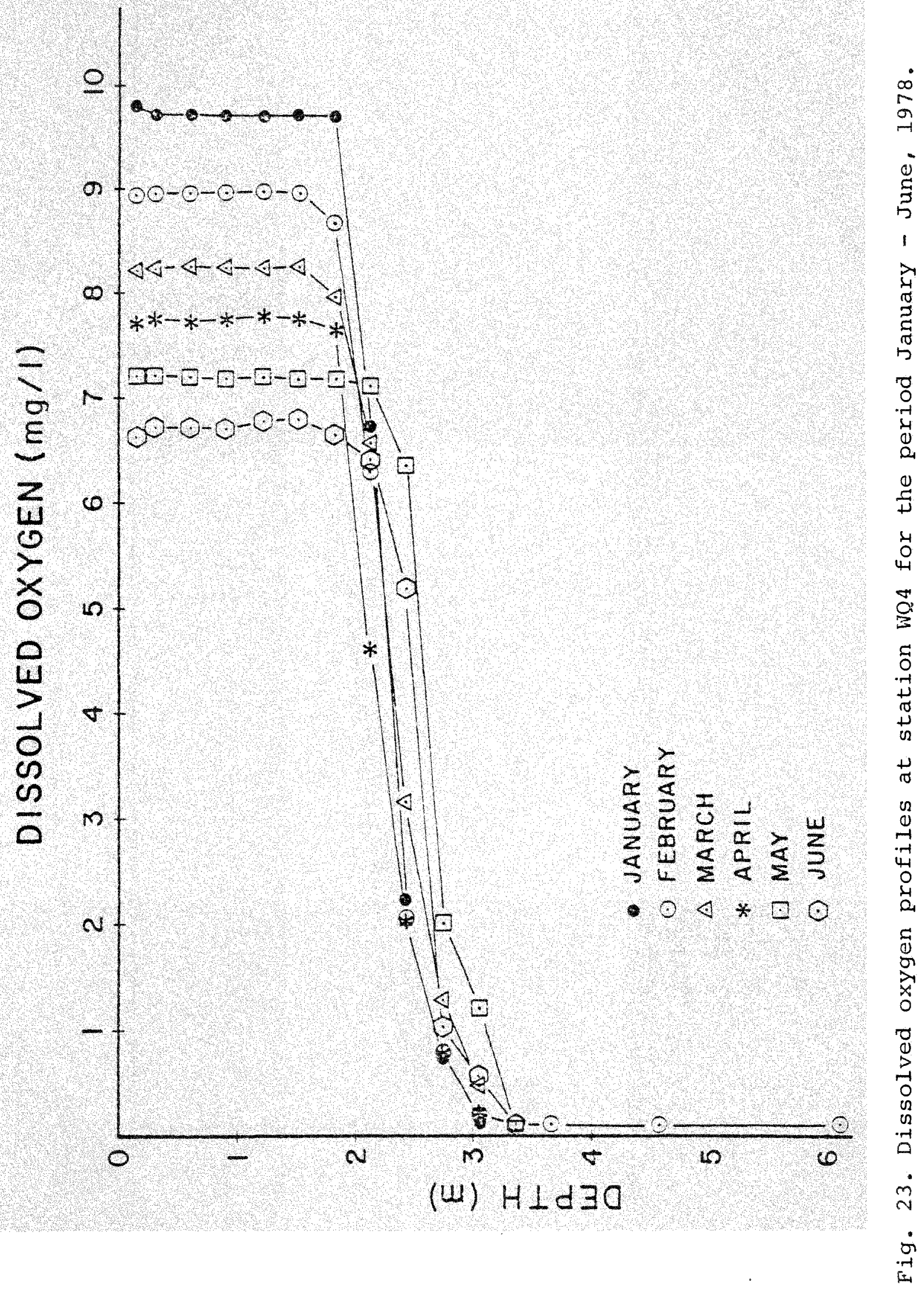




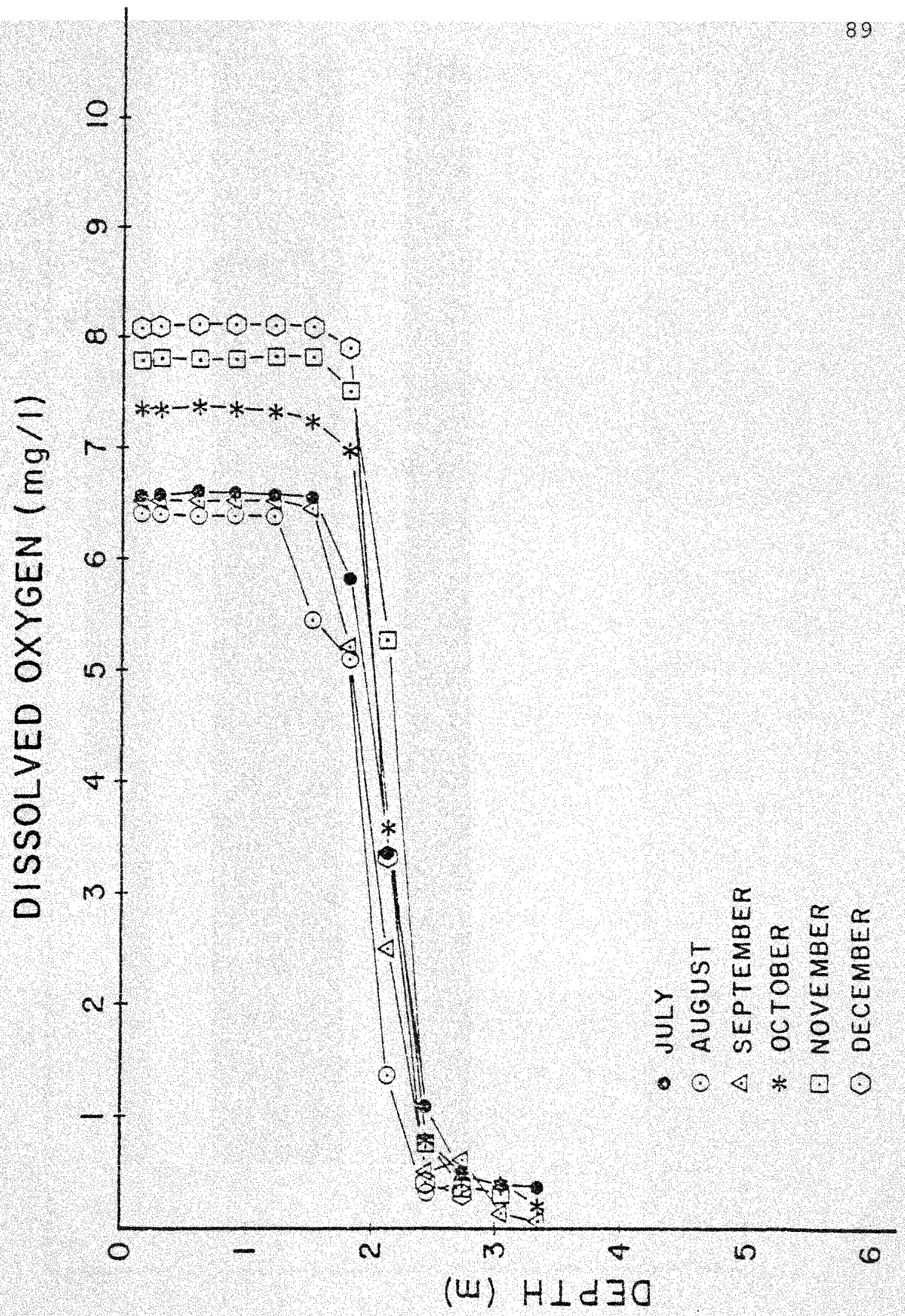




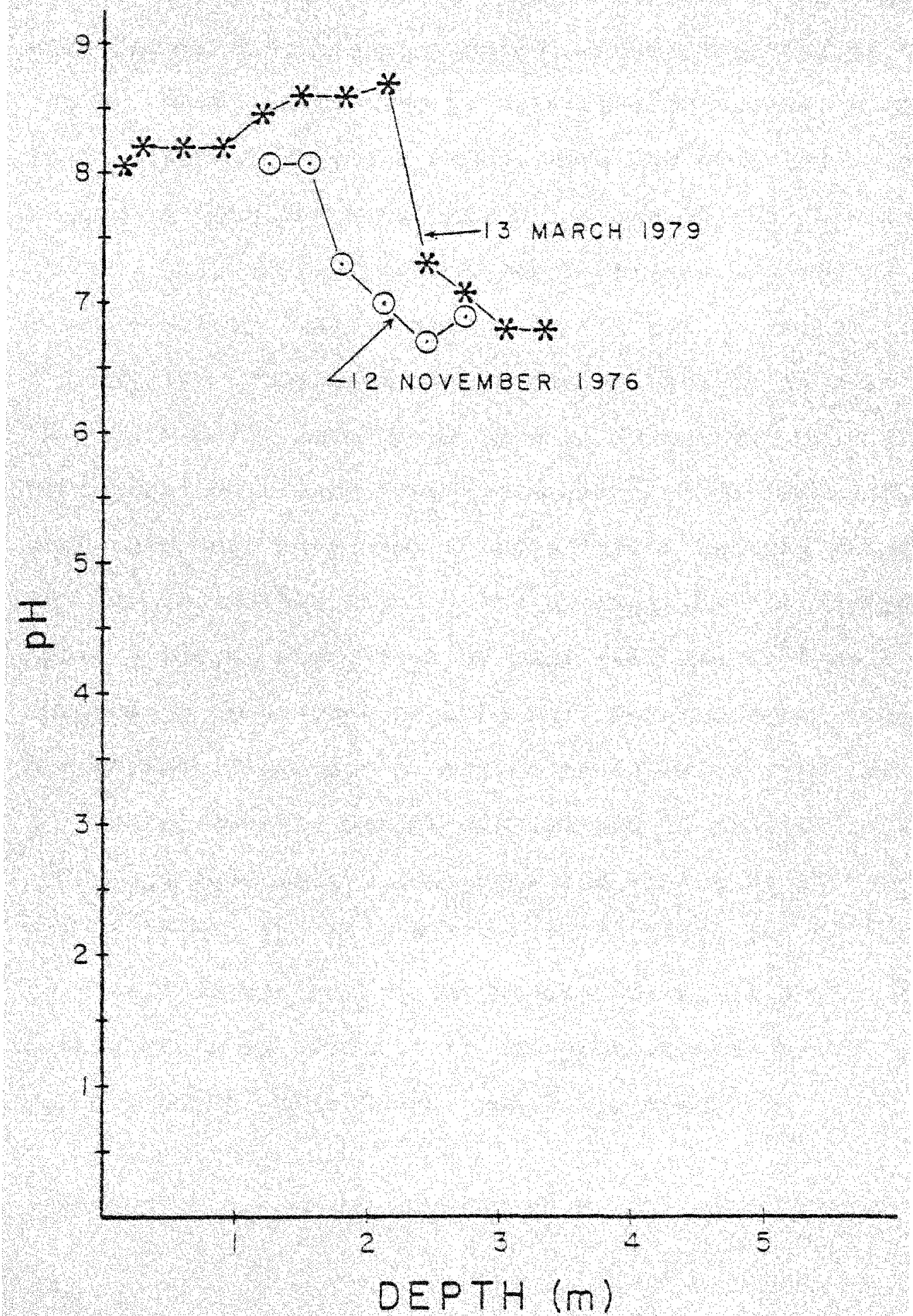

Fig. 25. A profile of hydrogen ion concentrations at Lake Marco Shores. 
Organic compounds. Monthly TKN values for the mixolimnion, chemocline and monimolimnion at Station WQ4 for 1978, are shown in Figure 26. These values included $\mathrm{NH}_{3}-\mathrm{N}$ together with organically bound nitrogen. Concentrations of the latter were calculated by substracting out $\mathrm{NH}_{3}-\mathrm{N}$ (Figure 2). Total kjeldahl nitrogen values were low over the study period in both the mixolimnion and chemocline $(x=0.96 \mathrm{mg} / 1$ and $x=0.79 \mathrm{mg} / 1$ ), respectively. Higher amounts of TKN were, however, always present in the monimolimnion $(\bar{x}=$ $3.13 \mathrm{mg} / 1)$. Ammonia-nitrogen concentrations in this layer $(\bar{x}=0.69 \mathrm{mg} / 1)$ made up as much as 22 percent of the TKN concentration. Data from the monimolimnion also indicated that there may have been an association between rainfall and TKN levels in this layer. The average TKN for the period April - August when $58 \mathrm{~cm}$ of rain fell was $4.51 \mathrm{mg} / 1$ as opposed to an average of $1.99 \mathrm{mg} / \mathrm{l}$ for the seven month period from September - March when $48 \mathrm{~cm}$ of rain fell. Total organic carbon was sampled in profile on 13 March, 1979, and the results are presented in Figure 27. Values ranged from a low of $6 \mathrm{mg} / \mathrm{l}$ in the mixolimnion to a high of $13.5 \mathrm{mg} / 1$ at the bottom of the chemocline $(3.0 \mathrm{~m})$. A bimodal distribution was evident in the profile with peaks at the $0.9 \mathrm{~m}$ ( secchi disk depth) and $3.0 \mathrm{~m}$ depths. 


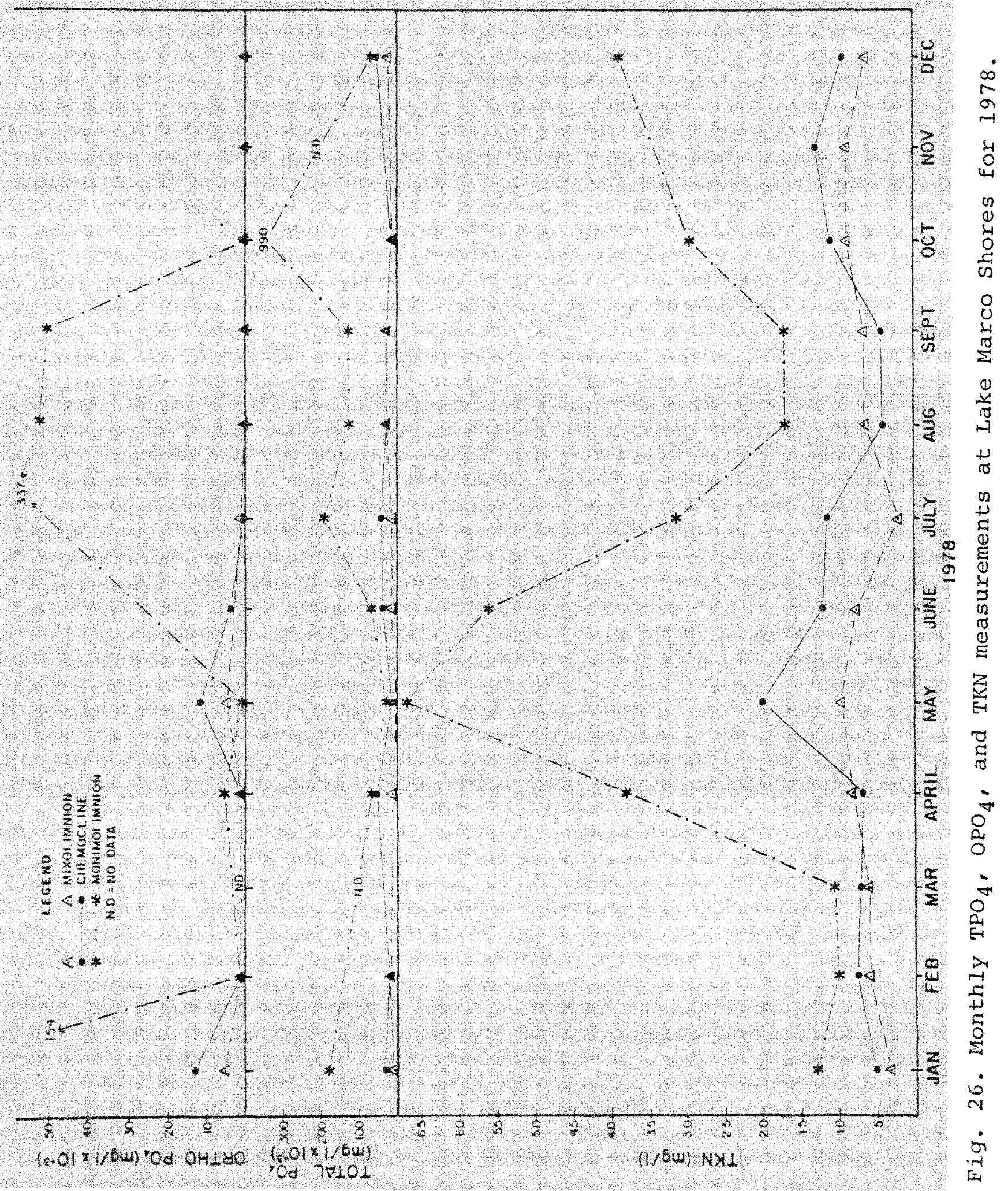




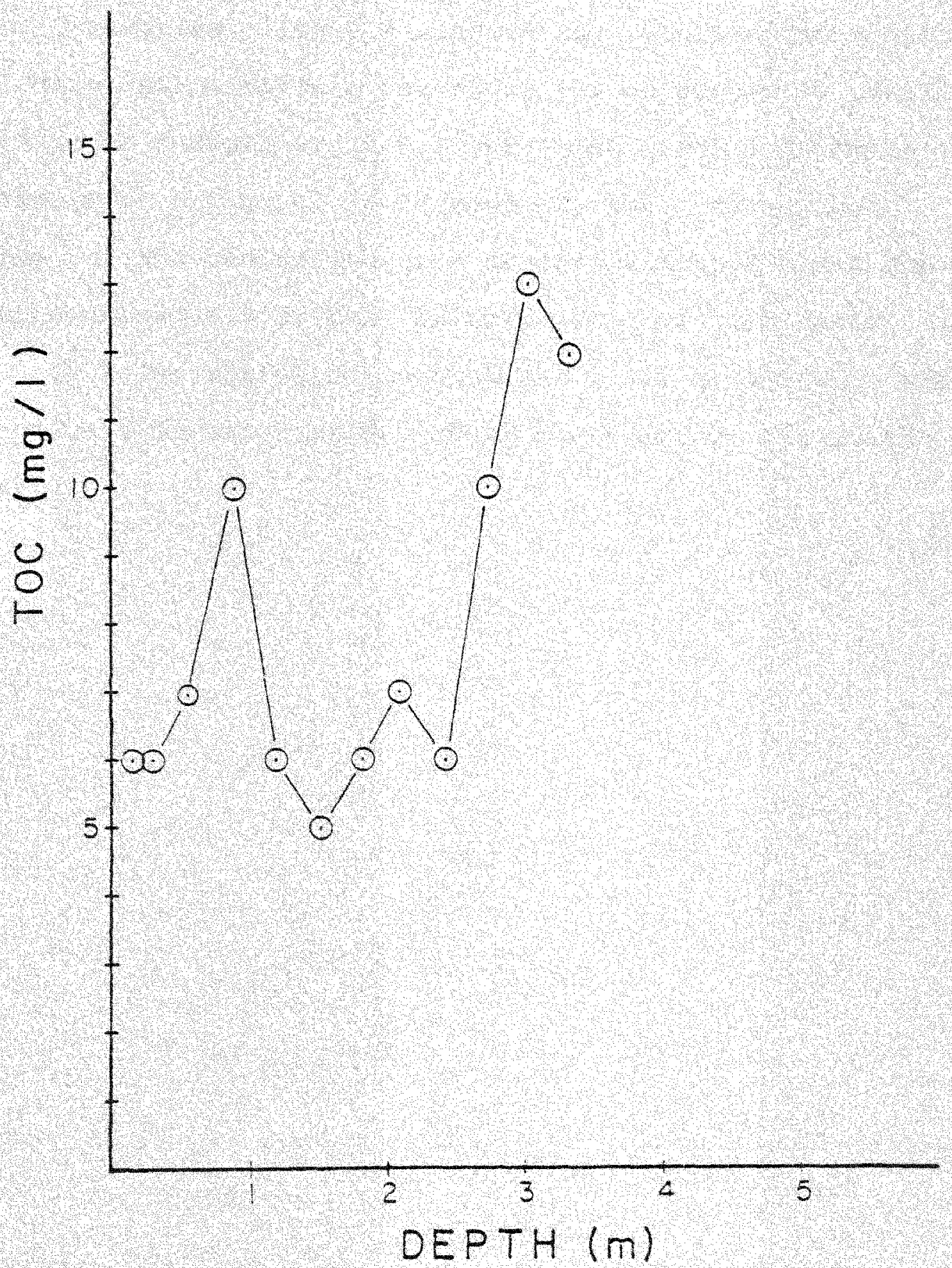

Fig. 27. A profile of total organic carbon at Lake Marco Shores. 
Conductivity. Conductivity reflects the total concentration of ionized substances dissolved in the water. Average monthly values for the water column at station WQ4 for this parameter are portrayed in Figures 28 and 29 . As with many other parameters, little variation was seen between months. Well mixed mixolimnionic waters of low conductivity usually extended to a depth of $2.0 \mathrm{~m}$ and ranged from 2.59 mmos in September to a high of 12.87 munos in May. The values chosen for the chemocline were an approximation since the meter continuously drifted in this layer of high ionic activity. The saline monimolimnion $(\sim 3.0 \mathrm{~m})$ was with one exception (February) always above the range of the salinometer. 


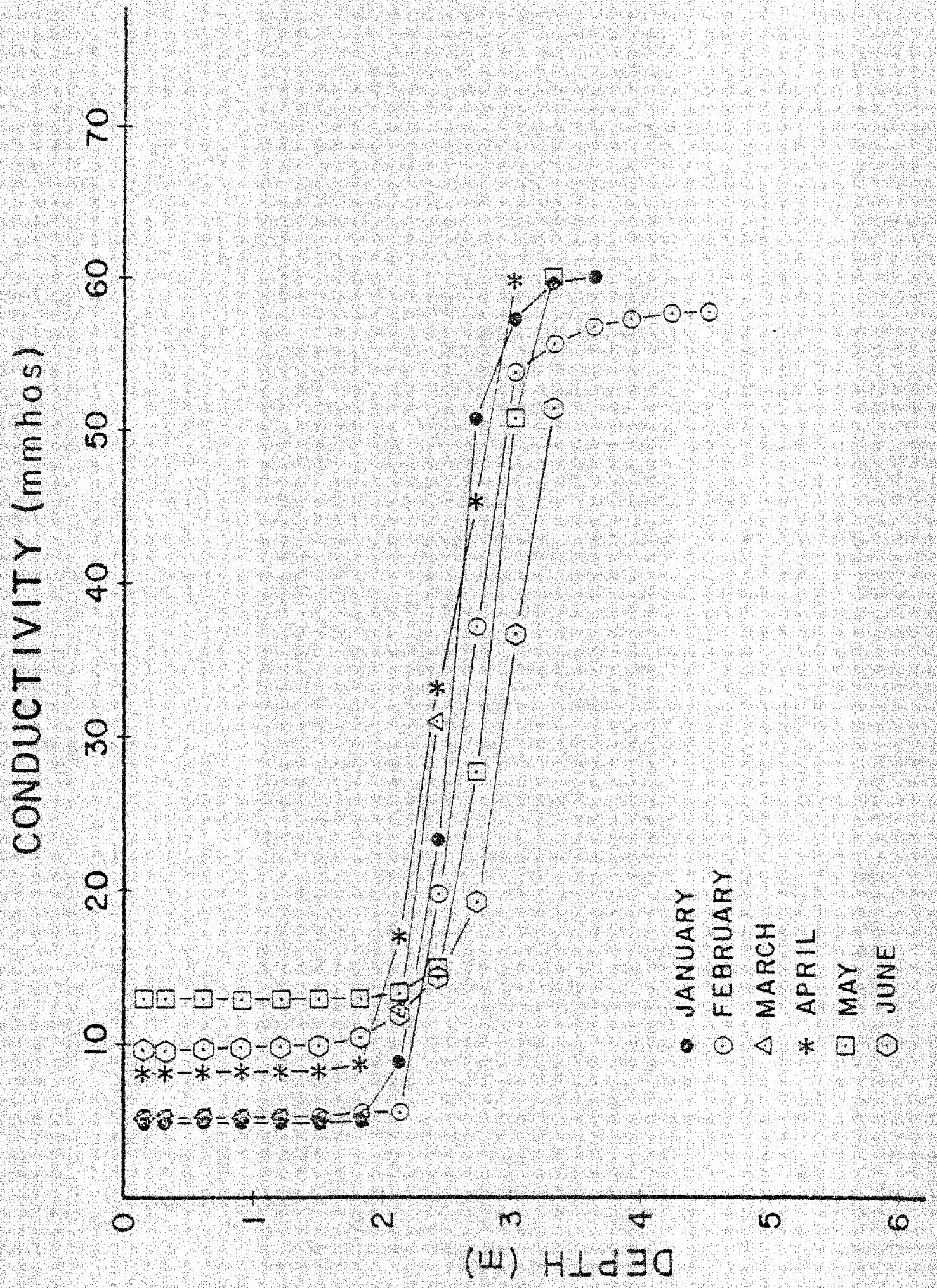

$\sum_{\infty}^{\infty}$

$\frac{0}{5}$ 


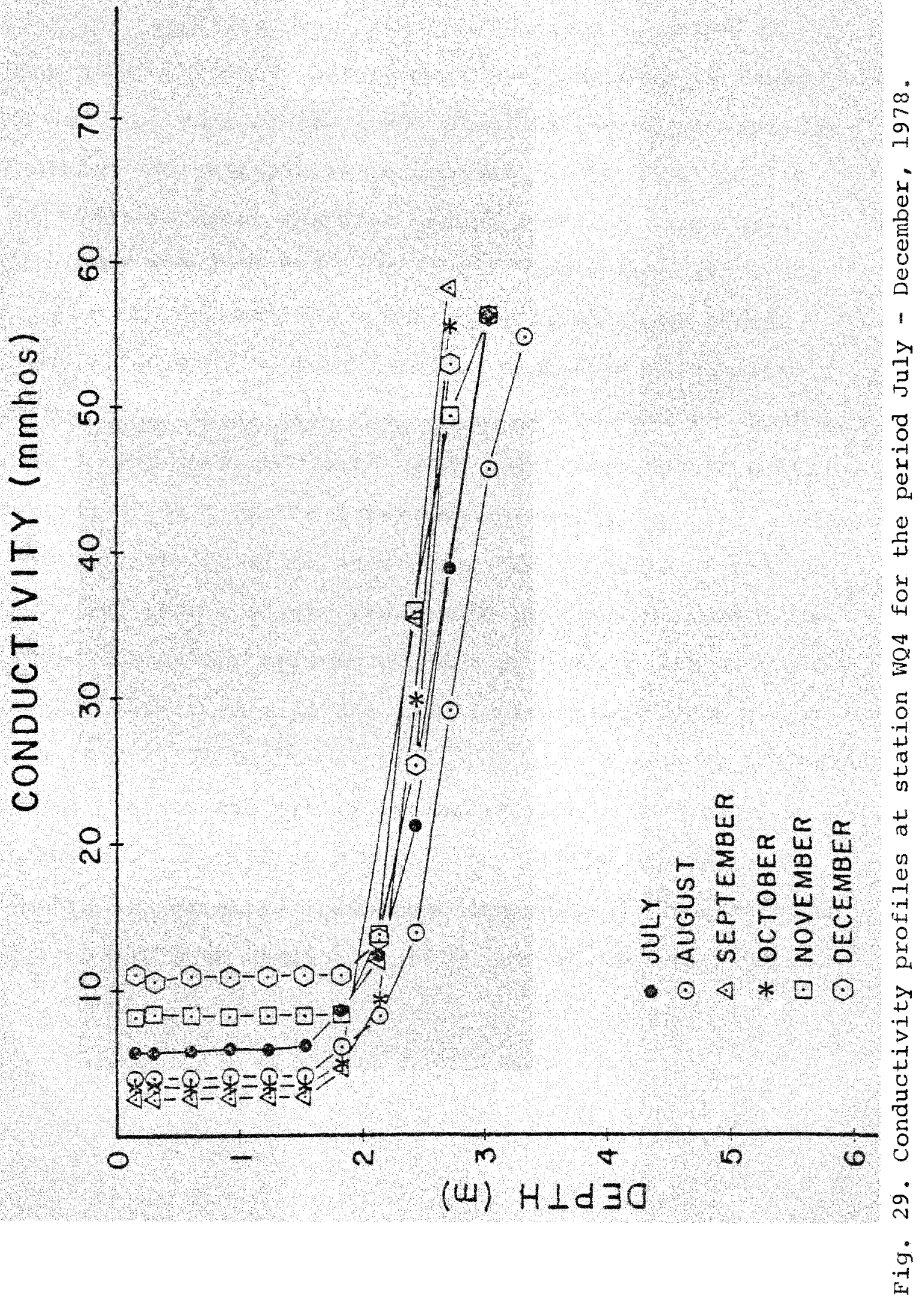


Inorganic constituents. The results from a series of "one time" chemical measurements are presented in Tables 10 and 11. None of the toxic elements listed in Table 10 exceeded the criteria as stipulated by the USEPA (1976b) for domestic water supplies except iron and manganese. Chlorides averaged $828 \mathrm{mg} / \mathrm{I}$ in the mixolimnion and 1,690 $\mathrm{mg} / 1$ in the chenocline, while the monimolimnion ranged from $23,546 \mathrm{mg} / 1$ to $26,781 \mathrm{mg} / 1$. Magnesium to chloride ratios were higher than what would be expected for surficial waters, but decreased with depth approximating the oceanic average $(0.067)$ in the lower monimolimnion.

Salinity profiles at Station WQ4 (Figures 30 and 31) indicated that a slight freshening of the mixolimnion occurred during the periods of January - March and July August. Salinities in the mixolimnion ranged from a low of $1.44 \%$ in September to a high of $7.3 \%$ in December. On the average salinities increased from 4-40\% with an increase of depth from $2 \mathrm{~m}$ to $3 \mathrm{~m}$. Stable hypersaline conditions prevailed throughout the year in the monimolimnion reaching an average of $43.0 \%$ at the $6.1 \mathrm{~m}$ depth. 
TABLE 10. The vertical distribution of selected inorganic constituents at Lake Marco shores.

Constituent

(mg/1)
Quality*

Criteria

(mg/1) $\frac{\text { Depth }(\mathrm{m})}{2.1}$

$0.2 \quad 2.7$
$1 / 31 / 78$

Silicate

$2 / 22 / 78$

Copper

Iron

Silver

Arsenic

Cadmium

Chromium

Mercury

Lead

$10 / 19 / 78$

Sulfate

Hardness

(as $\mathrm{CaCO}_{3}$ )

$11 / 8 / 78$

Copper

Iron

Magnesium

Manganese $\ldots \quad 0.40$

1.831

4.320
1.000

0.300

0.050

0.050

0.010

0.050

0.002

0.050
0.00700

0.04400

0.17000

0.00150

0.00430

0.00750

0.02500

0.00054

0.00670

0.00020

$4,260.0$

$7,900.0$

$\begin{array}{ll}---\quad 187.0 \\ -- & 556.0\end{array}$

$1,130.0$

$2,000.0$

$\begin{array}{rr}1.000 & 0.01530 \\ 0.300 & 0.42200 \\ -- & 443.00000 \\ 0.050 & 0.01140\end{array}$

0.00120

.00670

0.19200

.24000

716.00000

0.11400

$2,750.00000$

.21000

* Quality criteria of domestic water supplies from: USEPA (1976b) 
TABLE 11. The vertical distribution of chloride, color and turbidity at Lake Marco Shores on selected dates in 1978.

Constituent

$(\mathrm{mg} / \mathrm{I})$

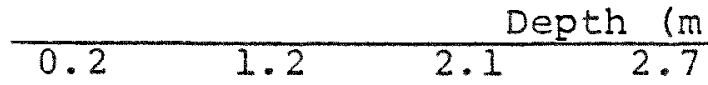

5.8

8.8

$1 / 31$

Chloride 383

$-\cdots$

$1,178 \quad 9,493$

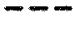

$--$

$2 / 22$

Chloride

1352

$--$

$3,304 \quad 7,922$

$7 / 5$

Chloride

Color

Turbidity *

$\begin{array}{rr}-- & 1,600 \\ -- & 45 \\ -- & 9\end{array}$

$\begin{array}{rr}-- & 11,254 \\ -- & 90 \\ -- & 1\end{array}$

23,593

65

26,963

17

150

$7 / 19$

Turbidity

$--$

1,470
2

$\begin{array}{rr}\ldots & 10,700 \\ \ldots & 3\end{array}$

23,500
25

26,600
4

$8 / 13$

Chloride Color

Turbidity*

750
120
2
1,999
110

$\begin{array}{rr}-- & 21,993 \\ --- & 200 \\ -- & 9\end{array}$

$---$

---
---
---

$10 / 19$

Color

Turbidity

70

$\begin{array}{rrr}85 & -- & 180 \\ 6 & -- & 160\end{array}$

$\begin{array}{ll}-- & -- \\ --- & --\end{array}$

* Turbidity measured in Nephthelometric Turbidity Units. 


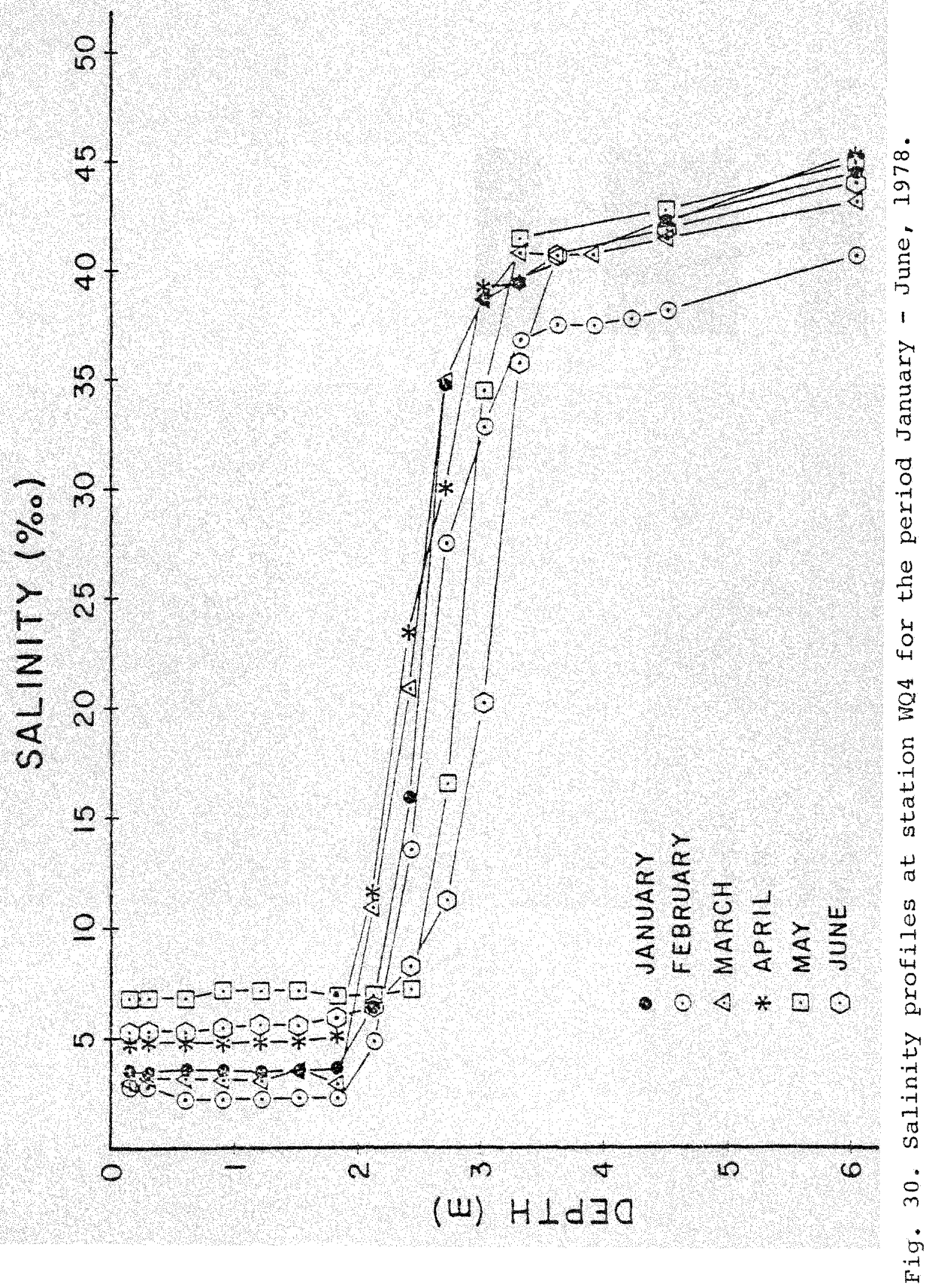




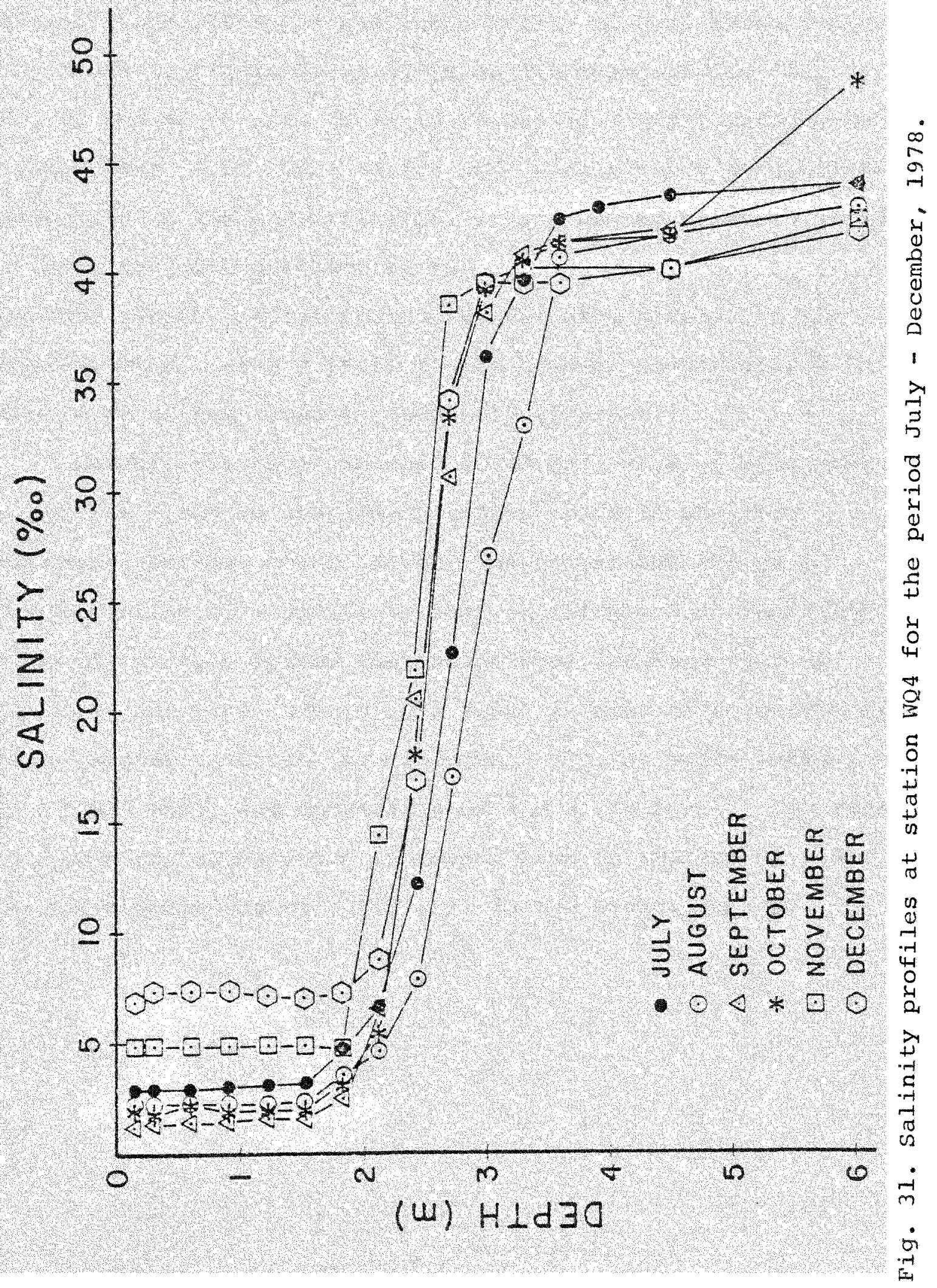


Total and orthophosphorus concentrations over an annual cycle (1978) in the three strata at Lake Marco Shores are shown in Figure 26 while three nitrogen species $\left(\mathrm{NH}_{3}-\mathrm{N}\right.$, $\mathrm{NO}_{3}-\mathrm{N}$, and $\mathrm{NO}_{2}-\mathrm{N}$ ) are shown in Figure 32. Total phosphorus ranged from $0.001 \mathrm{mg} / 1$ to $0.9 \mathrm{mg} / \mathrm{l}$ with highest concentrations occurring in the monimolimnion. There was no seasonal trend evident for this nutrient although there was a peak in the October sample. Total phosphorus was also highest in the monimolimnion, with a trend toward higher concentrations in the rainy season (June - September) apparent.

Ammonia-nitrogen averaged $0.545 \mathrm{mg} / \mathrm{l}(\mathrm{s} . \mathrm{d} .=0.481)$ over an annual cycle in the monimolimnion where it was most abundant, but was found in very low concentrations $(\bar{x}=$ $0.028 \mathrm{mg} / \mathrm{l} ; \mathrm{s} . \mathrm{d} .=0.035)$ in the mixolimnion and chemocline. Nitrate-nitrogen formed the second most abundant form of nitrogen but like ammonia, was found in greater concentrations with increasing depth (mixolimnion $\bar{x}=0.001 \mathrm{mg} / 1$; chemocline $\overline{\mathrm{x}}=0.016 \mathrm{mg} / 1$; and monimolimnion $\overline{\mathrm{x}}=0.018 \mathrm{mg} / 1)$. The same was true for $\mathrm{NO}_{2}-\mathrm{N}$ which increased from an average of $0.001 \mathrm{mg} / 1$ in the mixolimnion to $0.008 \mathrm{mg} / 1$ in the monimolimnion. 


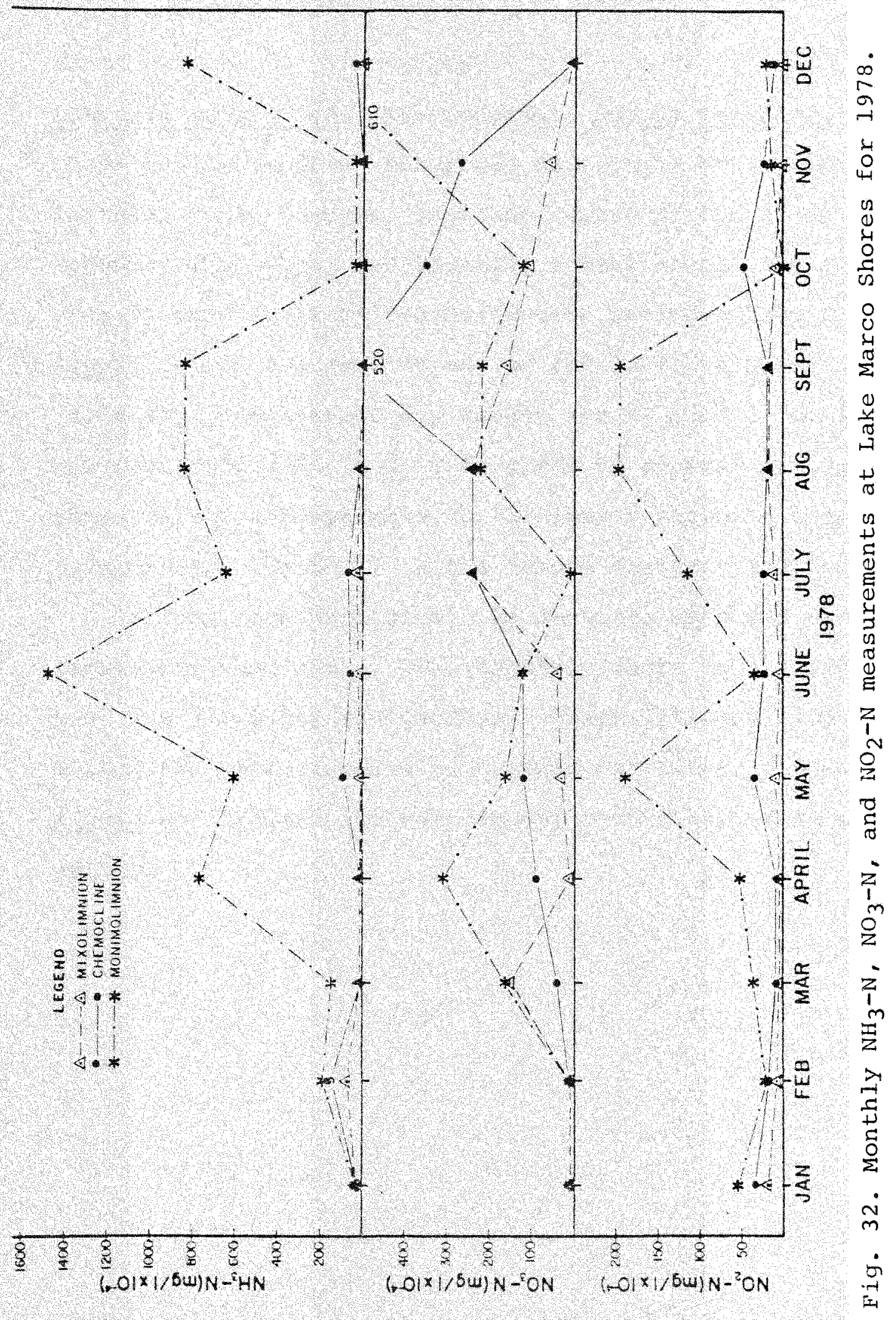




\section{BIOTA}

Iittoral Vegetation. The seagrass, Ruppia maritima, was the visually dominant submerged macrophyte of the lake's Iittoral zone, however, over the course of the study it appeared that Chara was becoming established. The results of a 20 core $\left(0.02 \mathrm{~m}^{2}\right)$ standing crop estimate from a Ruppia bed in the eastern end of the lake are shown in Table 12. The average dry weight was $92 \mathrm{~g} / \mathrm{m}^{2}$ (s.d. $=43$ $\mathrm{g} / \mathrm{m}^{2}$ ) with $51 \mathrm{~g} / \mathrm{m}^{2}$ (s.a. $=62 \mathrm{~g} / \mathrm{m}^{2}$ ) of ashfree dry weight. These data are comparable to the lowest standing crop determinations (Table 1) in the lake's drainage area.

As has been mentioned, red mangrove bordered the lake's northern shore. The southern shore on the other hand was virtually unvegetated. Where littoral slopes permitted the establishment of an emergent flora, cattails (Typha sp.) formed the most recently established floral stands. 
TABLE 12. A standing crop determination for Ruppia maritima at Lake Marco Shores - 14 March 1978.
Dry Weight $\left(\mathrm{g} / \mathrm{m}^{2}\right)$
Ash-free Weight $\left(\mathrm{g} / \mathrm{m}^{2}\right)$

70
74

130

50

245

75

105

110

80

70

100

140

70

70

55

80

55

80

85

90

30

12

162

34

19 
Microplankton. The results of monthly analyses of mixolimnion, chemocline and monimolimnion microplankton are sumarized in Figure 33. A species list is included in Table 13. The flagellates dominated the overall catch forming a significant proportion ( $>50$ percent) of all monimolimnion samples. This group was also occasionally abundant in the chemocline with peaks occurring in January and in the May - June and October - November periods. Blue green algae (Myxophyceae) formed the second most numerically important group. They generally occurred only in the mixolimnion and chemocline and were abundant only in the october samples from the mixolimnion. The diatoms were similarly restricted to the mixolimnion and chemocline but like the dinoflagellates (Dinophyceae), desmids, Chlorophycea and tintinids which shared these top layers, they were not quantitatively important. Besides the flagellates, only the ciliates appeared regularly in the monimolimnion. Among the three lake strata total microplankton counts were highest in the June monimolimnion samples reaching $3.42 \times 10^{6}$ cells per liter. October and November counts were, however, greater when the whole water column was considered.

There was further evidence of high phytoplanktonic activity in Figure 19 which includes monthly concentrations of chlorophyll a and its breakdown product, phaeophytin. Concentrations of chlorophyll a reached $382 \mathrm{mg} / \mathrm{m}^{3}$ in the 


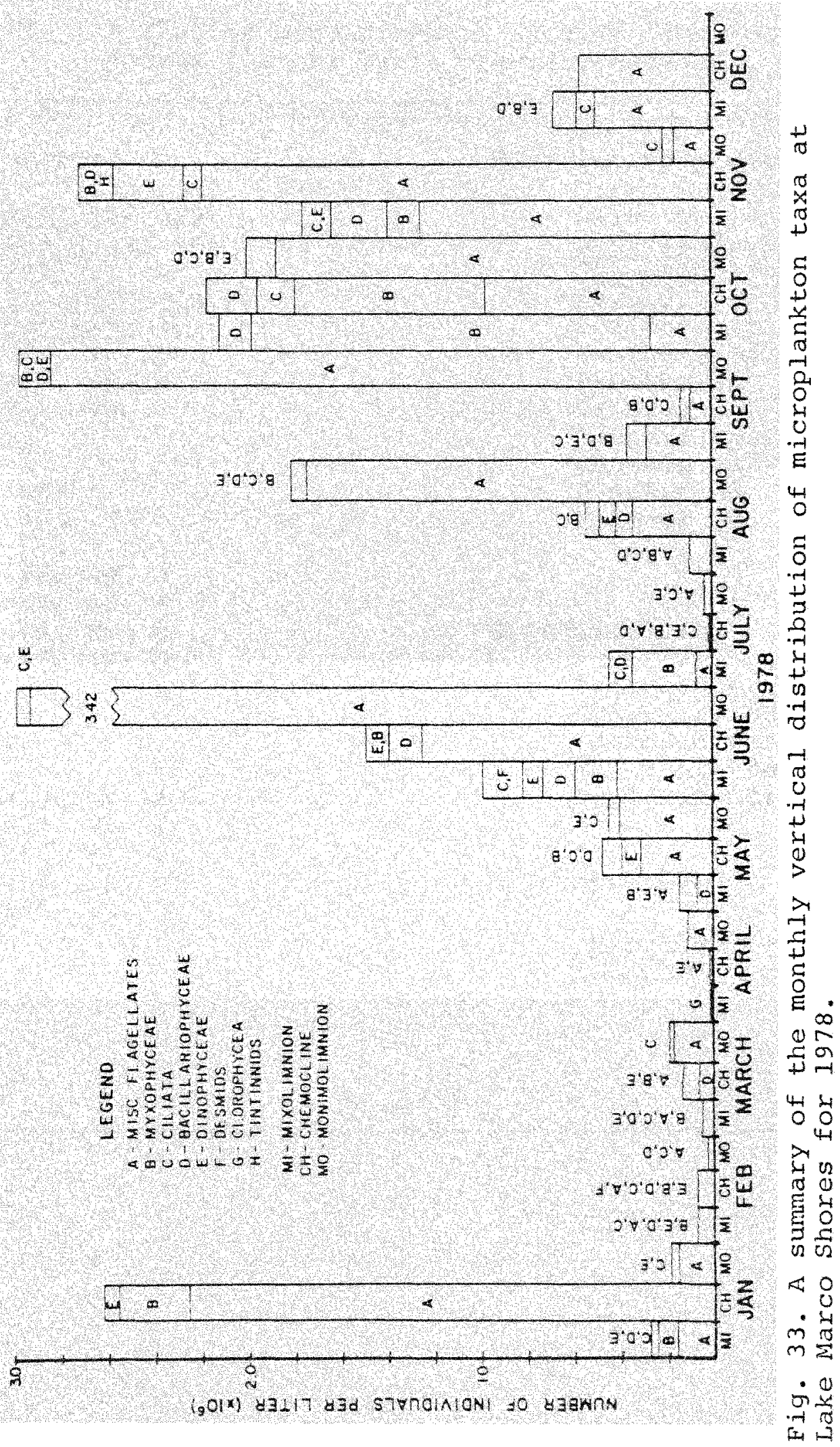


TABLE 13. A list of microplankton species from Lake Marco Shores for the period January-December, 1978.

Cyanophyceae

Anacystis spp.

Agmenellum sp.

Anabaena sp.

Aphanizomenon sp.

Spirulina sp.

unid. sp. A

unid. sp. B

unid. sp. C

Fiagellata

unid. sp. A

unid. sp. B

unid. sp. C

unid. sp. D

Ciliata

unid. sp. A

unid. sp. $B$

unid. sp. C

unid. sp. D

unid. sp. E
Bacillariophyceae

unid. sp. A

Cyclotella sp.

Coscinodiscus sp.

Navicula sp.

Centrate sp. A

Centrate sp. B

Pennate sp. A

Pennate sp. B

Pennate sp. C

Pennate sp. D

Pennate sp. E

Pennate sp. F

Dinoflagellata

Prorocentrum sp. Gymnodinildae sp. A Gymnodiniidae sp. B Peridinioidea sp. A Peridinioidea sp. B

Chlorophyceae

Tetraedron sp. Scenedesmus sp. 
top of the monimolimnion simultaneous with a peak in ciliate abundance (Figure 33). A similar pattern was evident in October, but those samples showed higher chlorophyll a in the surface and chemocline relative to the monimolimnion. On an annual basis chlorophyll a averaged $73.2 \mathrm{mg} / \mathrm{m}^{3}(\mathrm{~s} . \mathrm{d}$. = $107.3 \mathrm{mg} / \mathrm{m}^{3}$ ) in the top of the monimolimnion, $28.6 \mathrm{mg} / \mathrm{m}^{3}$ $\left(\mathrm{s} . \mathrm{d} .=60.5 \mathrm{mg} / \mathrm{m}^{3}\right)$ in the chemocline, and $33.2 \mathrm{mg} / \mathrm{m}^{3}(\mathrm{~s} . \mathrm{d} .=$ 84.1) in the mixolimnion. As has been mentioned (Figure 27) total organic carbon analyses also tended to reinforce the observation that production peaks at the top of the saline monimolimnion. 
Zooplankton. Table 14 includes a list of the zooplankton species collected from the three main strata of Lake Marco Shores during 1978 .

The Rotifera were the numerically dominant zooplankton phylum, and they included five species in three genera. One species Branchionus c.f. urceolaris, was the most abundant of all zooplankton species. Seasonal changes in the abundance of this species in each of the three lake strata are portrayed in Figure 34. This species was most abundant in the chemocline and secondarily so at the top of the monimolimnion. Nighttime samples from these layers always contained higher numbers of this species than daytime samples (Figure 35). Two abundance peaks were evident: one in the May monimolimnion samples and the other in the NovemberDecember period in the chemocline. This species was not well represented, however, in mixolimnionic samples. Rotifers of the genus Nothalca were, on the other hand, only found in mixolimnionic and chemocline samples. This surface water species peaked in the March and september-october samples (Figure 36 ).

The copepods formed the numerically dominant arthropod taxa with the cyclopoid, Microcyclops sp., being the most abundant. The relative distribution of this species among the three strata in the lake is given in Figure 37. Microcyclops so. was virtually absent from mixolimnionic samples but appeared in all samples from the two lower layers. Densities of this species in the chemocline were usually 
TABLE 14. Zooplankton species collected at Lake Marco

Shores - January-December, 1978.

Protozoa

Tintinnida

unidentjfied species

Aschelminthes

unidentified species

Rotifera

Monogonta

Branchionus c. E. urceolaris Müller

Branchionus havanaensis Rousselet

Notholca sp. A

Notholca sp. B

Eilinia opoliensis Zach.

Mollusca

Bivalvia

unidentified veligers

Arthropoda

Arachnida

Acarina

unidentified mite

Crustacea

Branchiopoda

Diplostraca

Cladocera

Bosmina c. E. coregoni Baird

Diaphanosoma c. f. brachyurum Liévin

Copepoda

unidentified nauplii

Cyclopoida

Microcyclops sp.

Microcyclops copepodites

Calanoida

Acartia sp.

Acartia copepodites

sp. A

sp. B

Malacostraca

Isopoda

unidentified species

Decapoda

unidentified branchyuran megalops

Insecta

Diptera

unidentified larva 


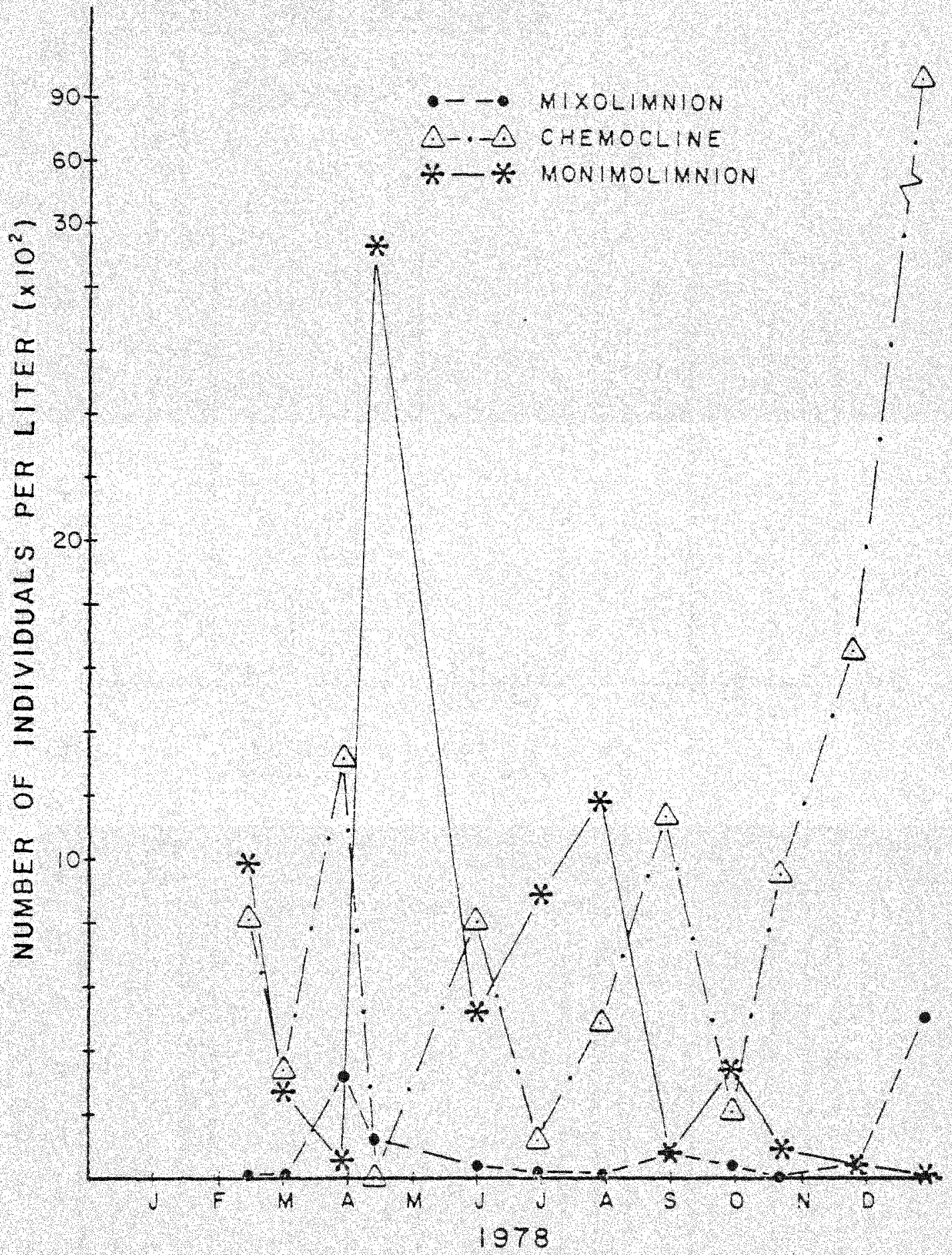

Fig. 34. The monthly relative distribution of Branchionus urceolaris in the three main strata of Lake Marco Shores for 1978 . 

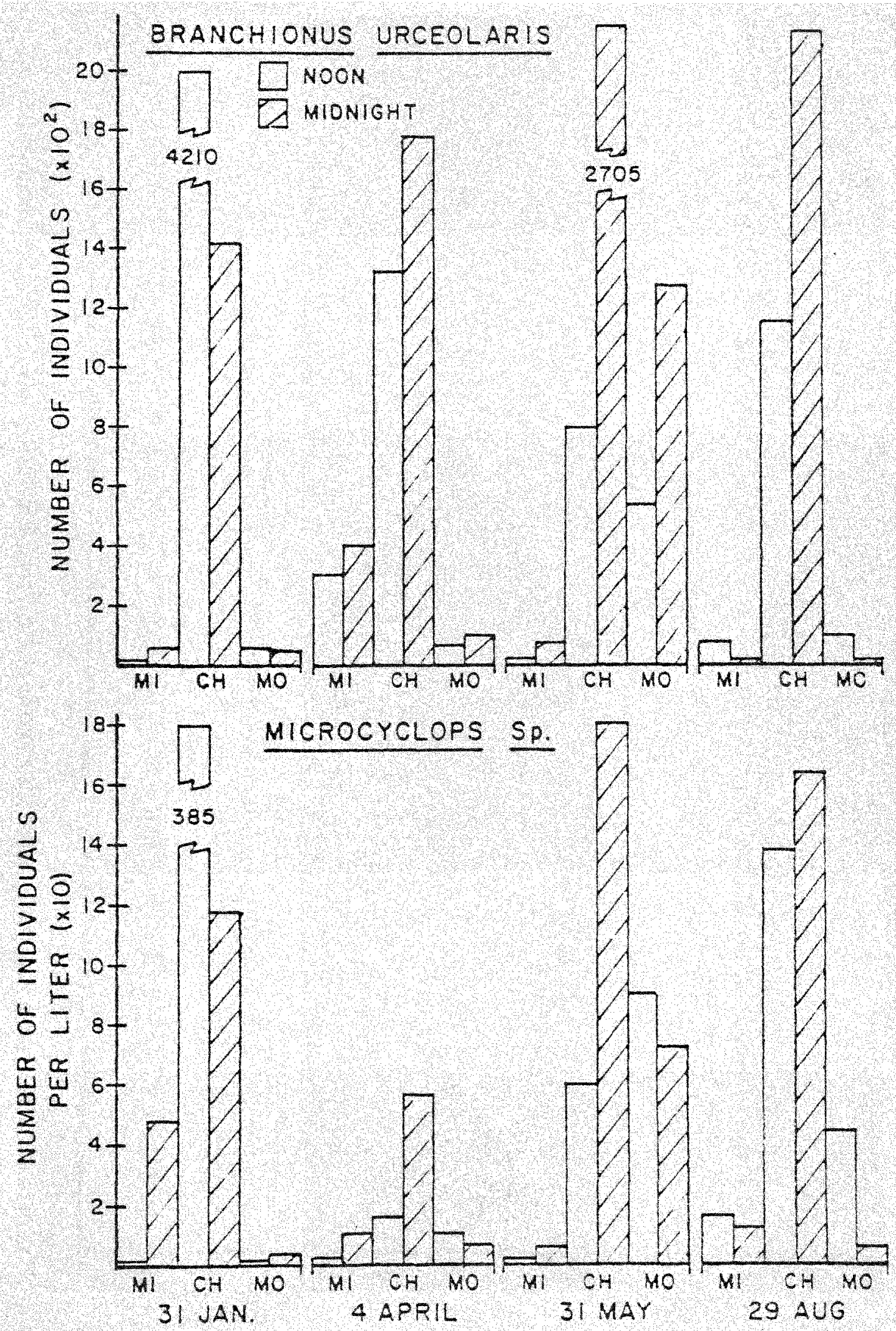

Fig. 35. The noon vs. midnight distribution of Branchionus urceolaris and Microcyclops sp. in quarterly samples from the mixolimuion (MI) chemocline (CH) and monimolimnion (MO) at Lake Marco Shores. 


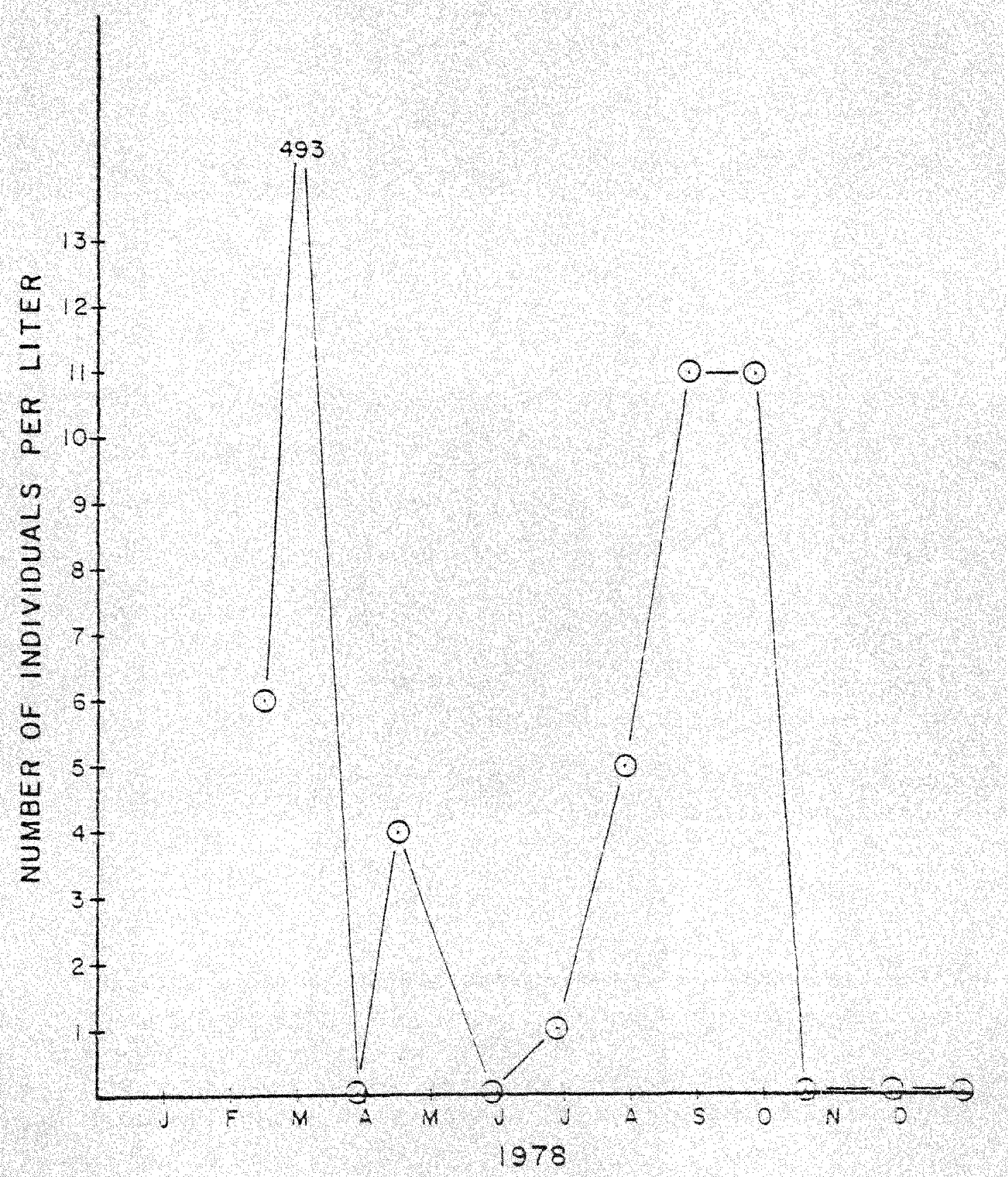

Fig. 36. The monthly abundance of Nothalca in 1978. 


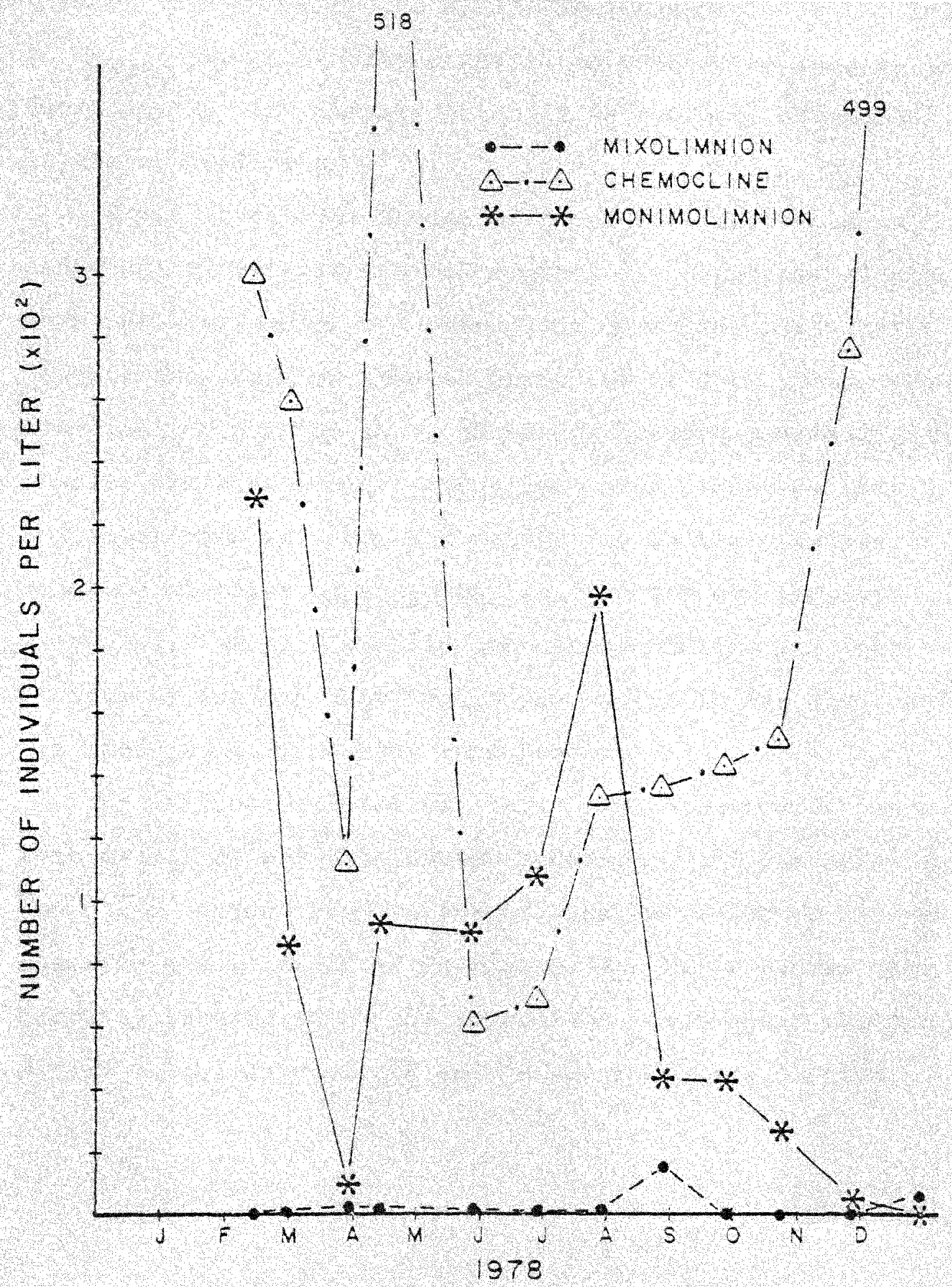

Fig. 37. The monthly relative distribution of Microcyclops sp. from the three main strata of Lake Marco shore for 1973. 
greater than those of the monimolimnion except for the July to August period. Peaks occurred in chemocline samples in February, May and January but only in February and August in the monimolimnion.

There is circumstantial evidence that this species underwent a vertical diurnal migration. Nighttime samples from the mixolimnion and chenocline contained more individuals than daytime samples three out of four times (Figure 35 ). On each of these occasions daytime monimolimnion samples contained more Microcyclops than nighttime monimolimnion samples. Monthly variations in the relative abundance of three Microcyclops life stages are shown in Figure 38. Nauplii usually outnumbered adults and copepodites by greater than two to one except in May when nearly six times as many nauplii were present.

An unidentified veliger larva was a seasonally important member of the zooplankton community, and its relative abundance in the three strata of Lake Marco Shores over an annual cycle is depicted in Figure 39. These larvae were narrowly restricted to the chemocline where their abundance peaked in the July-August and December-January periods. 


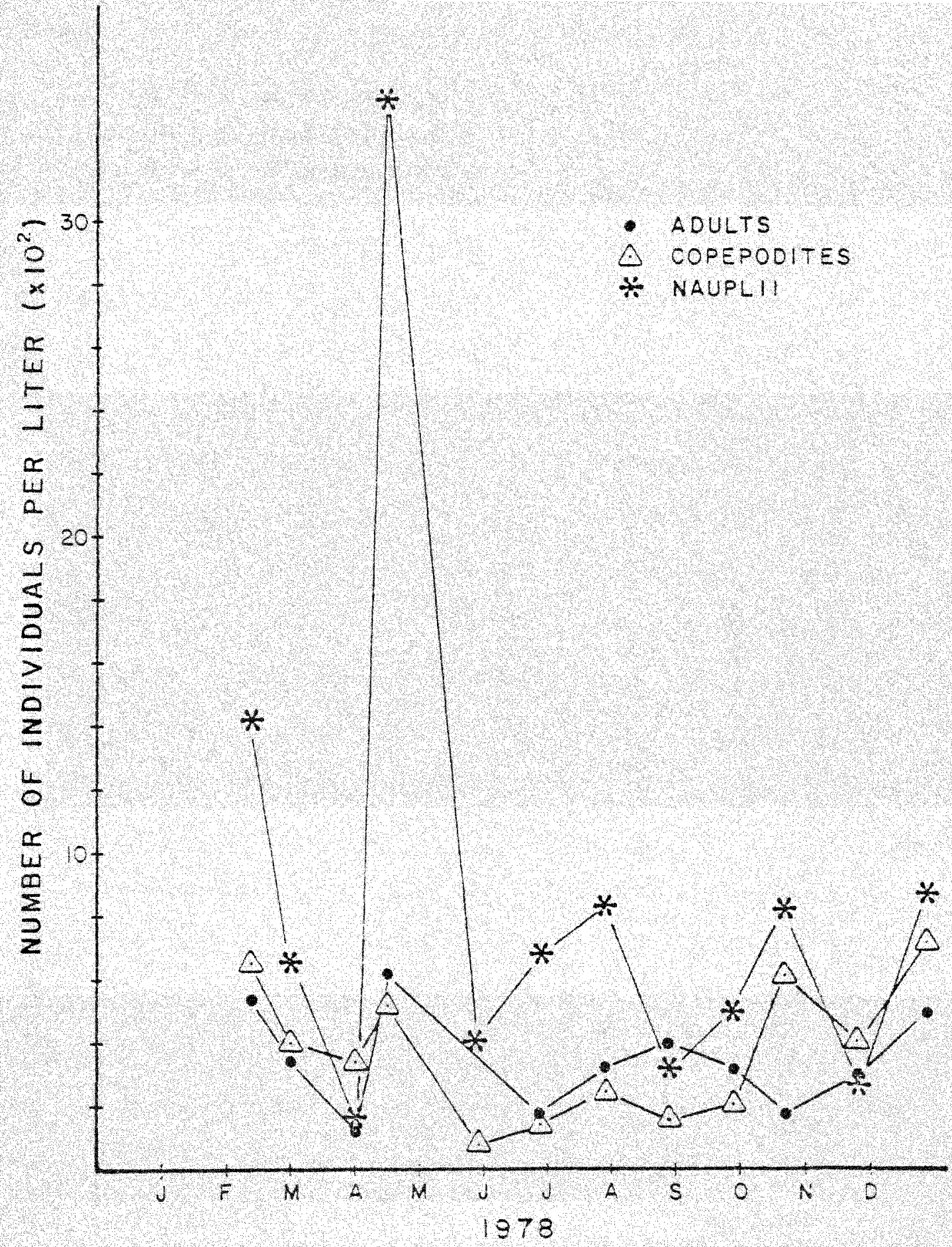

Fig. 33. Monthly variations in the relative abundance of three Microcyclops life stages for 1978. 


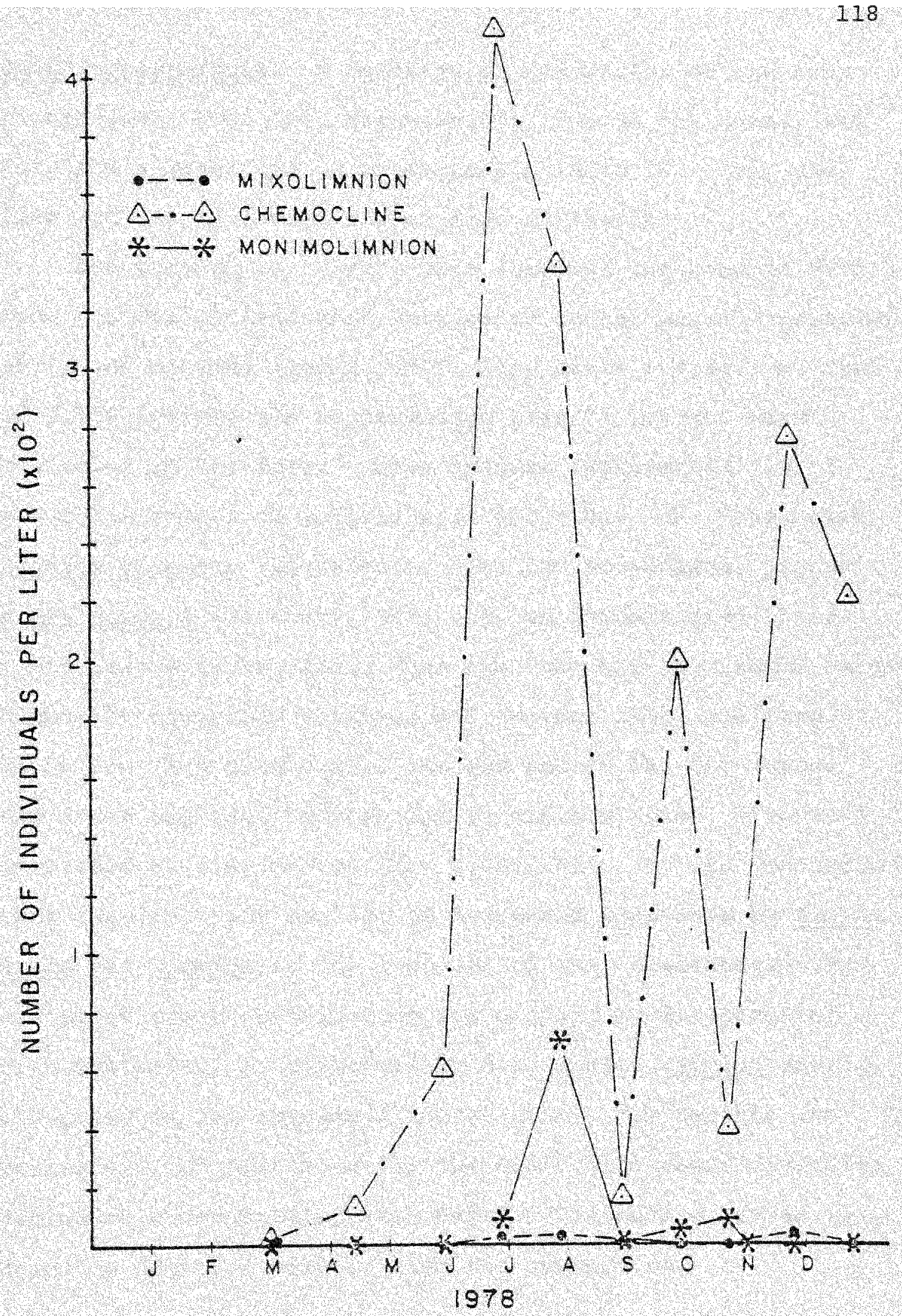

Fig. 39. The monthly relative distribution of an unidentified vileger larva in the three main strata of Lake Marco Shores for 1978 . 
Benthic macrofauna. A qualitative comparison of the crustacean fauna from Lake Marco Shores, the SR 951 canal, and the lake's watershed is presented in Table 15. Only the lake and its watershed showed high similarity.

Courtney et al. (1977) have reviewed the benthic data from the collections that were taken during maximum (January, 1977) and minimum (Apri1, 1977) lake water stages. A total of 2,716 individuals representing over 22 species were collected in the lake. Three species represented $89 \%$ of the total number of individuals collected: the razor clam, Tagelus plebeius (Lightfoot), 42\%; the polychaete, Laeonereis culveri (Webster), 34\%; and, an unidentified chironomid insect larva, $13 \%$. When the lake was at maximum stage community diversity (Shannon and Weaver, 1949) was found to be low $(\bar{H}=0.20-0.50)$. At the end of the dry season and after the lake had receded to minimum stage, diversity increased at most depths $(\overline{\mathrm{H}}=0.20-1.25)$. It was concluded that this increase was due to decreased dominance by Laeon-

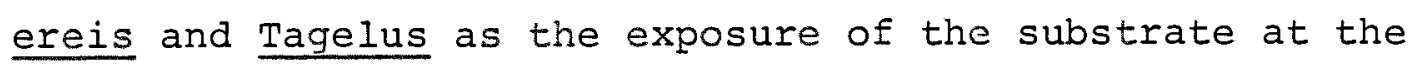
center of their distribution was exposed to desiccation. High mortality, as evidenced by dead intact Tagelus shells, was noted in the exposed littoral zone. The benthic community did not persist below the chemocline where diversity decreased exponentially with depth. Chironomid larvae were found to dominate samples from the chemocline. 


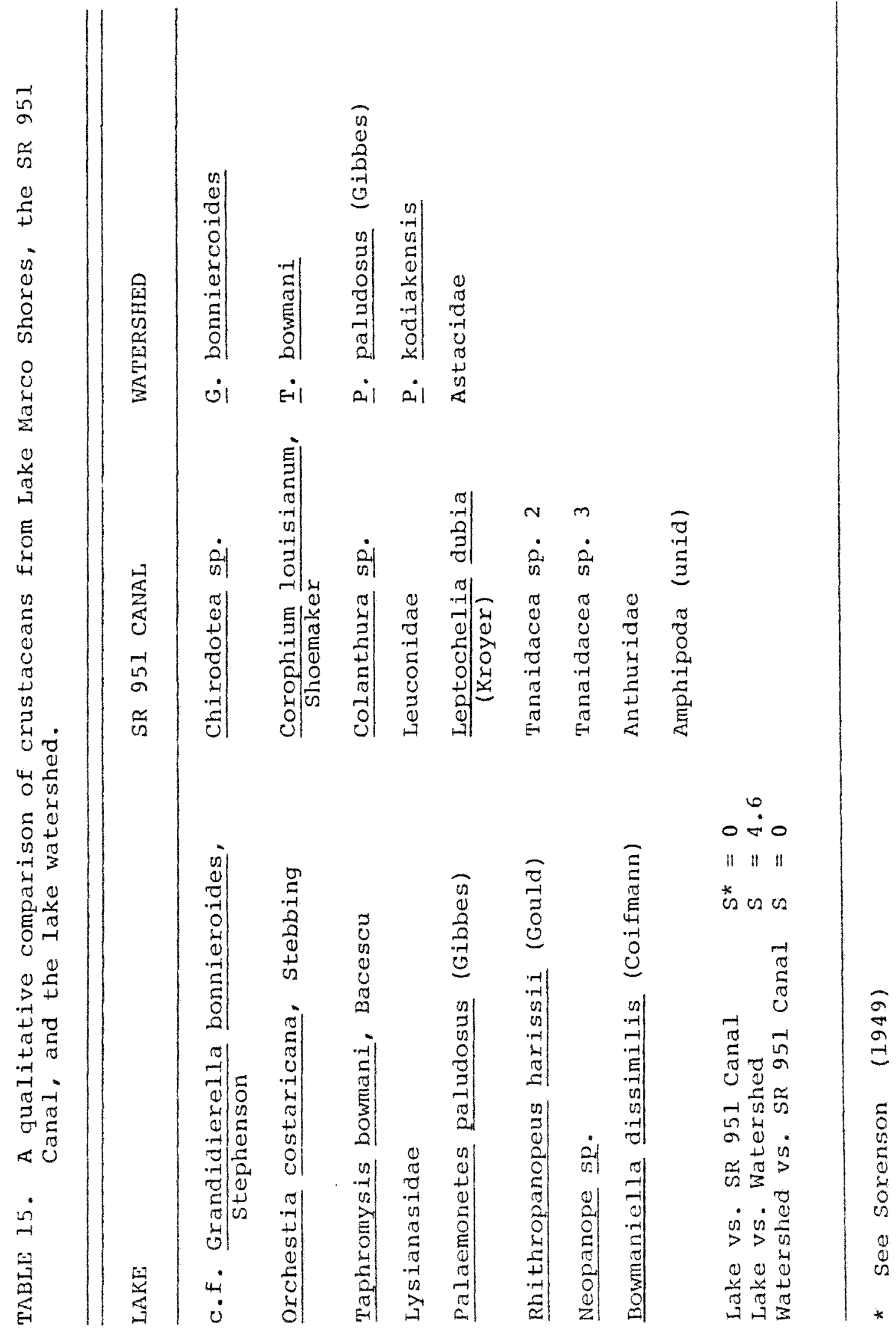


The results of the 1978 bimonthly benthic sampling for all depths combined are shown in Table 16. Twentythree species comprising 1,291 individuals were collected. Laeonereis culveri, was the numerical dominant accounting for $55 \%$ of the total catch. This polychaete peaked in abundance in the April-June period, but never made up an important part of the benthic biomass. A small brackishwater gastropod, c.f. Assimineidae, accounted for $16 \%$ of the total catch, while two bivalves, Mytilopsis leucophaeata and Tagelus plebeius accounted for $12 \%$ of the catch. Together, the Mollusca accounted for $82 \%$ of the total annual community biomass. Tagelus abundance peaked in June but this species was absent from all collections during the remainder of the year. Mytilopsis abundance peaked in December.

The arthropods did not form an important part of the total annual benthic biomass (6\%), but this phylum was represented by more species (17) than any other phylum. Total community biomass peaked in June $\left(119 \mathrm{~g} / \mathrm{m}^{2}\right)$, and was confined throughout the year to depths of less than 2.7 meters. Total community species diversity (Shannon and Weaver, 1949) was calculated for each sample and the results are depicted in Figure 40 . There was a linear decrease in diversity during the period February to August when a low for the year $(\overline{\mathrm{H}}=0.92)$ was reached. Diversity climbed rapidy, however, during the october to December period when the naximum annual diversity (1.80) was found. 


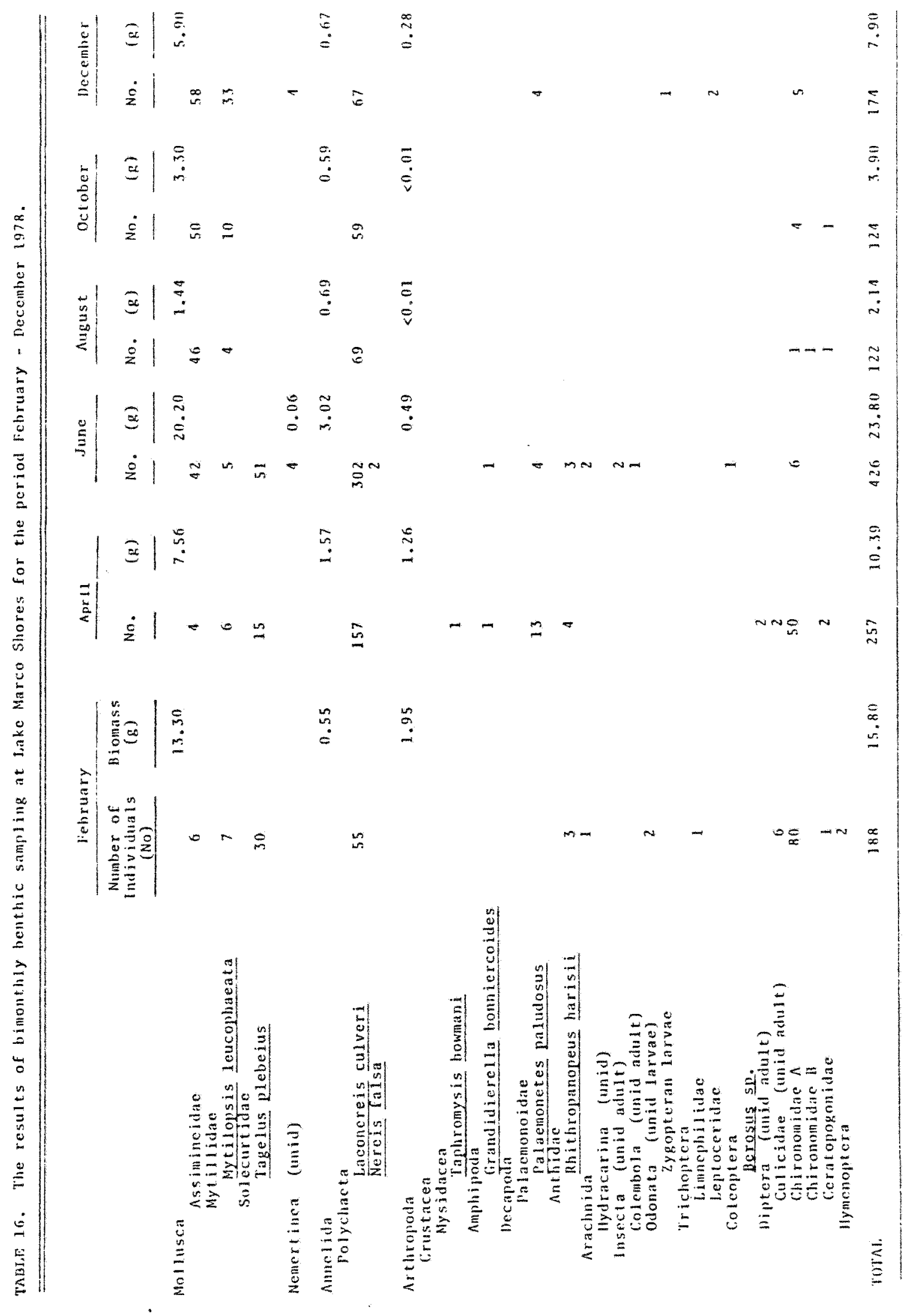




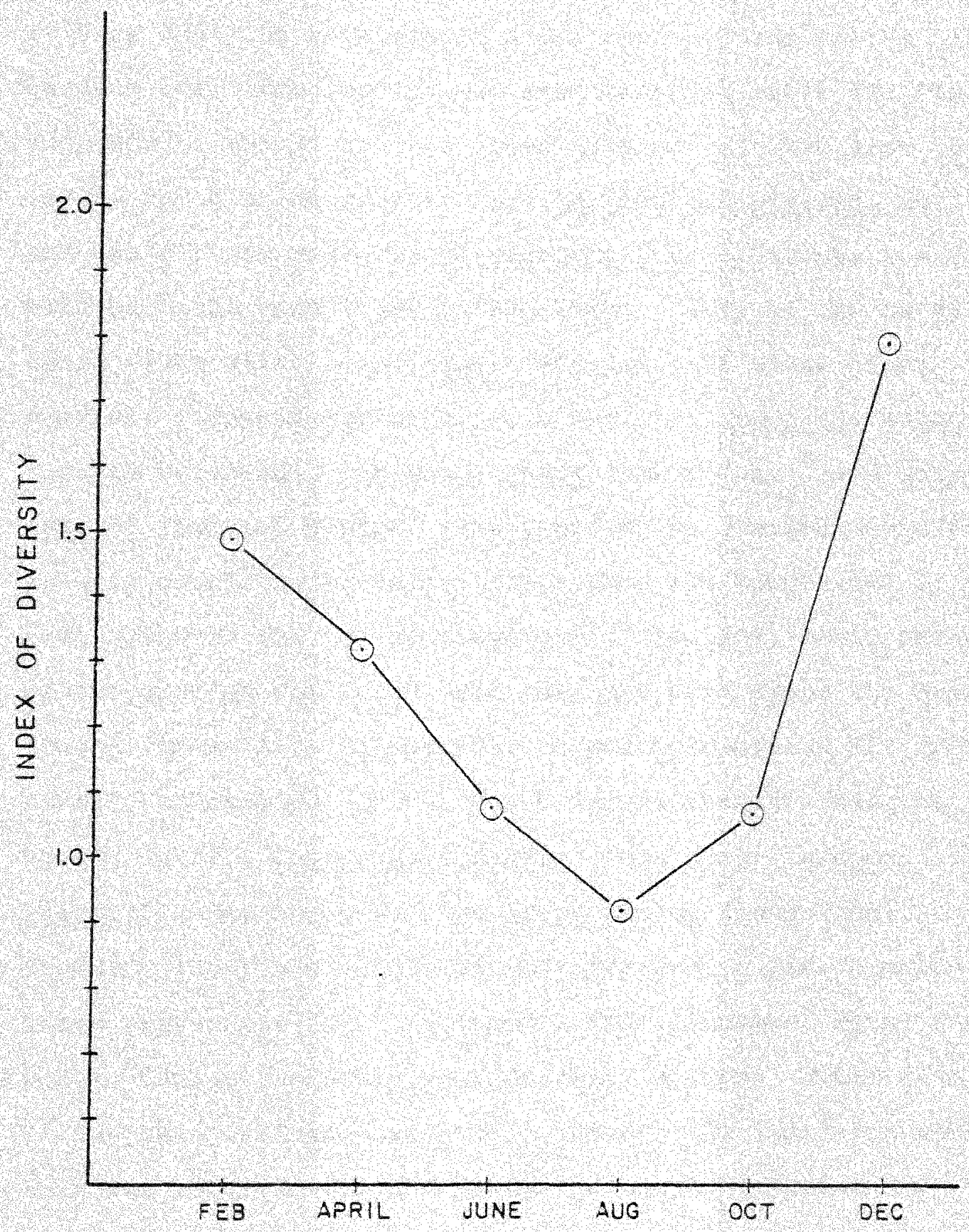

Fig. 40. The Shannon and Weaver index of diversity for the total benthic community at Lake Marco Shores for 1978. 
Fishes. No fish collections were made as part of my study, however, Finan (1979) made a qualitative collection in May, 1979 by applying rotenone to a 0.1 hectare area at the lake's eastern end. His results are summarized in Table 17. In addition to the 27 species noted by Finan, I have also observed the Florida spotted gar, Lepisosteus platyrhincus, and the striped mojarra, Diapterus plumieri, in the lake. Both of these were found by Brockmann (1974) in the SR 951 canal along with 10 additional species. Of these, four species: Lepomis macrochuris (bluegill), Ictalurus natalis (yellow bullhead), Gobiosoma bosci (naked goby), and Notropus emiliae (pugnose minnow) were typified by Brockmann (1974) as only occurring at salinities within the range that I have observed for the mixolimnion at the lake. Only three of the species collected from the lake were among the more common fishes (i.e. those that together comprized $97 \%$ of the total fish sampled) in the Marco Island estuary (Weinstein et al. 1977): Gobiosoma robustum (code goby), Anchoa mitchelli (bay anchovy), and Elops saurus (lady fish). Browder (1978) has suggested that freshwater fish populations spread out into the marshes from permanent water bodies during the south Florida rainy season. Water levels in the lake drainage basin (c.f. Figure 17) indicated that this was possible for the fishes of the lake during the July-August period.

During the cold spell of 20 January 1977, I observed that only the striped mojarra was killed by the temperature 
TABLE 17. Merristic data for the fishes collected from Lake Marco Shores during the period 16-17 May, 1979. (Extracted from Finan, 1979)

Species

Number Total of Weight

Individual

(g)
Biomass

$\left(\mathrm{g} / \mathrm{m}^{2}\right)$
Adinia zenica (Jordan and Gilbert)

Anchoa mitchilli Hildebrand

Centropomus undecinalis (Block)

Cyprinodon variegatus Lacepede

Diapterus olisthostomus

(Goode and Bean)

Elops saurus Linnaeus

Fundulus confluentus

(Goode and Bean)

Fundulus grandis Baird and Girard 2

Fundulus Similis (Baird and Girard) 3

Fundulus seminolis Girard

Gambusia affinis

(Baird and Girard)

Gobiosoma robustum (Pallas)

Heterandria formosa Agassiz

Jordanella floridae Goode and Bean

Lagodon rhomboides (Linnaeus)

Lepomis gulosus (Valenciennes)

Lepomis microlophus (Gunther)

Lepomis punctatus (Valenciennes)

Lucania parva (Baird and Girard)

Lophogobius cyprinoides (Pallas)

Megalops atlantica Valenciennes

Menidia beryllina (Cope)

Microgobius gulosus (Girard)

Micropterus dolimieu Lacepede

Mugil cephalus Linnaeus

Poecilla latipinna (Lesueur)

Syngnathus scovelli

Gobiidae spp.

(Evermann and Marsh)
2

10

1

55

2

3

5

1

106

2

15

53

1

11

21

13

18

171

13

111

30

1

4

340

2

1
0.8

11.0

454.0

35.8

193.0

1815.0

4.9

28.1

56.6

0.4

13.8

0.5

1. 5

31.4

159.0

83.4

64.5

22.9

5.5

225.6

$19,390.0$

31.5

11.1

212.0

3595.0

244.3

1.6

0.2

0.01

0.01

0.41

0.03

0.17

1.64

0.01

0.03

0.05

0.01

0.01

0.01

0.01

0.03

0.14

0.08

0.06

0.02

0.01

0.20

17.55

0.03

0.01

0.19

3.25

0.22

0.01

0.01 
depression (air temperatures reached $-2.2^{\circ} \mathrm{C}$ ). This species may have been completely eliminated from the lake at this time. 
Community metabolism. The results of the USEPA gross primary productivity measurements in the standing water surrounding the emergent vegetation communities in the lake watershed are shown in Figures 41-45. Oxygen production at each station exhibited a classical bell-shaped curve over a diurnal cycle with peak production occurring between 1500 and 1800 hours in the late afternoon.

Gross primary productivity ranged from a low of 4.0 $\mathrm{g} / \mathrm{m}^{2} /$ day at station $\mathrm{B}$ south (Figure 43 ) which was located in $0.4 \mathrm{~m}$ of water in a moderately dense Eleocharis meadow to a high of $12.1 \mathrm{~g} / \mathrm{m}^{2} /$ day in a pond containing the submerged macrophyte, Chara sp. (Figure 45). The wide range in diffusion constants $(k)$ in these areas was probably due to the differing depths and degrees of openness of the respective study sites. Hence, $k$ was highest at sites $A-8$ and B-north which were relatively open and shallow (i.e. $0.3 \mathrm{~m}$ and $0.2 \mathrm{~m}$, respectively).

Respiration nearly equalled production (i.e. $P / R$ ranged from 1.01 to 1.28 ) at all of the watershed sites except $A-8$ where there was high respiration relative to production (Figure 41 ).

A different pattern was evident, however, in the metabolism measurements in the water column at Lake Marco Shores. If production had been determined by integration over the whole water column, the large respiration of oxygen demanding substances (e.g. $\mathrm{H}_{2} \mathrm{~S}$ ) inherent in the lower saline 


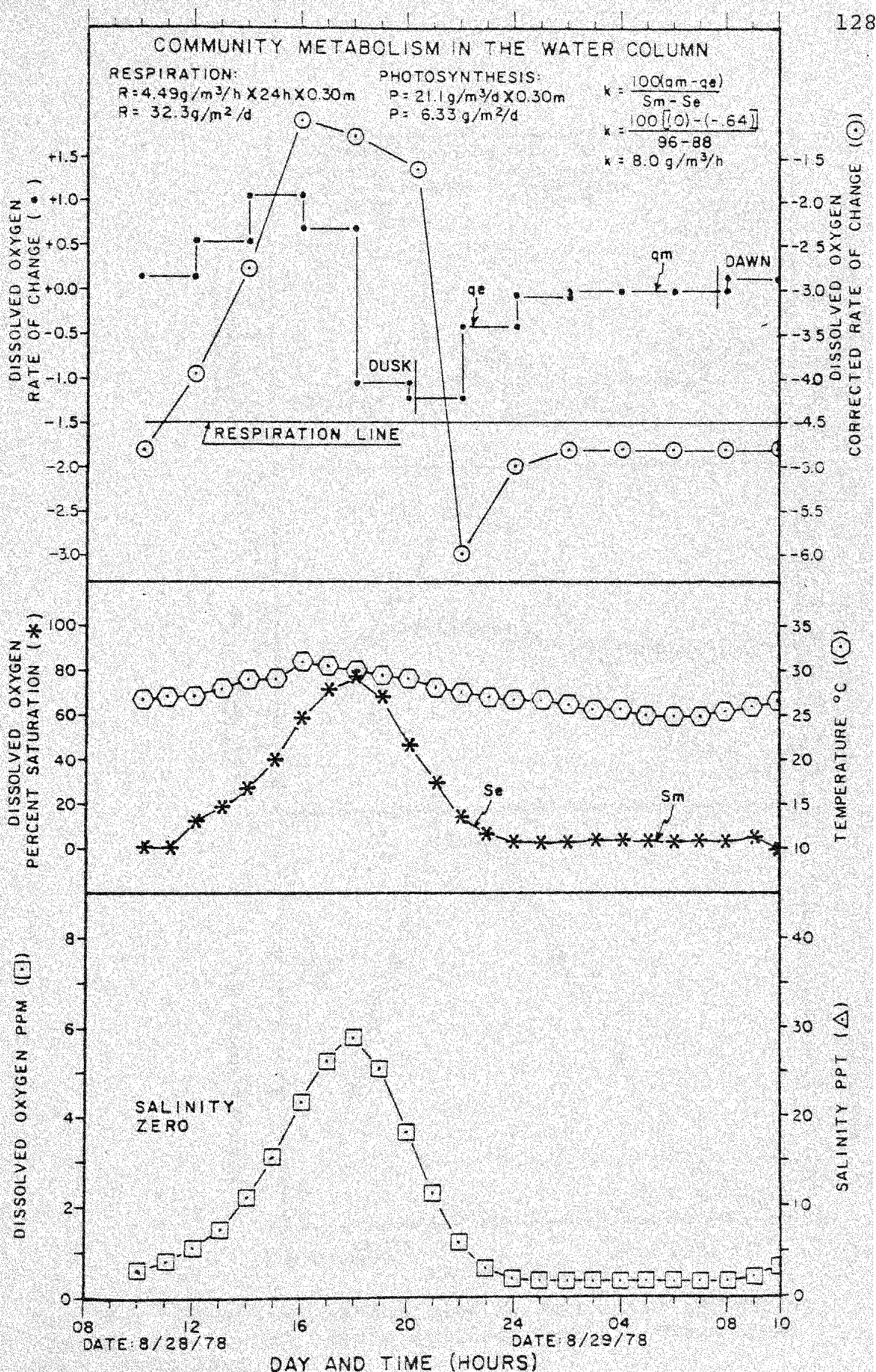

Fig. 41. Community metabolism* in the water column at station $\mathrm{A} 3$ in the lake's drainage basin. *Extracted from USEPA data. 


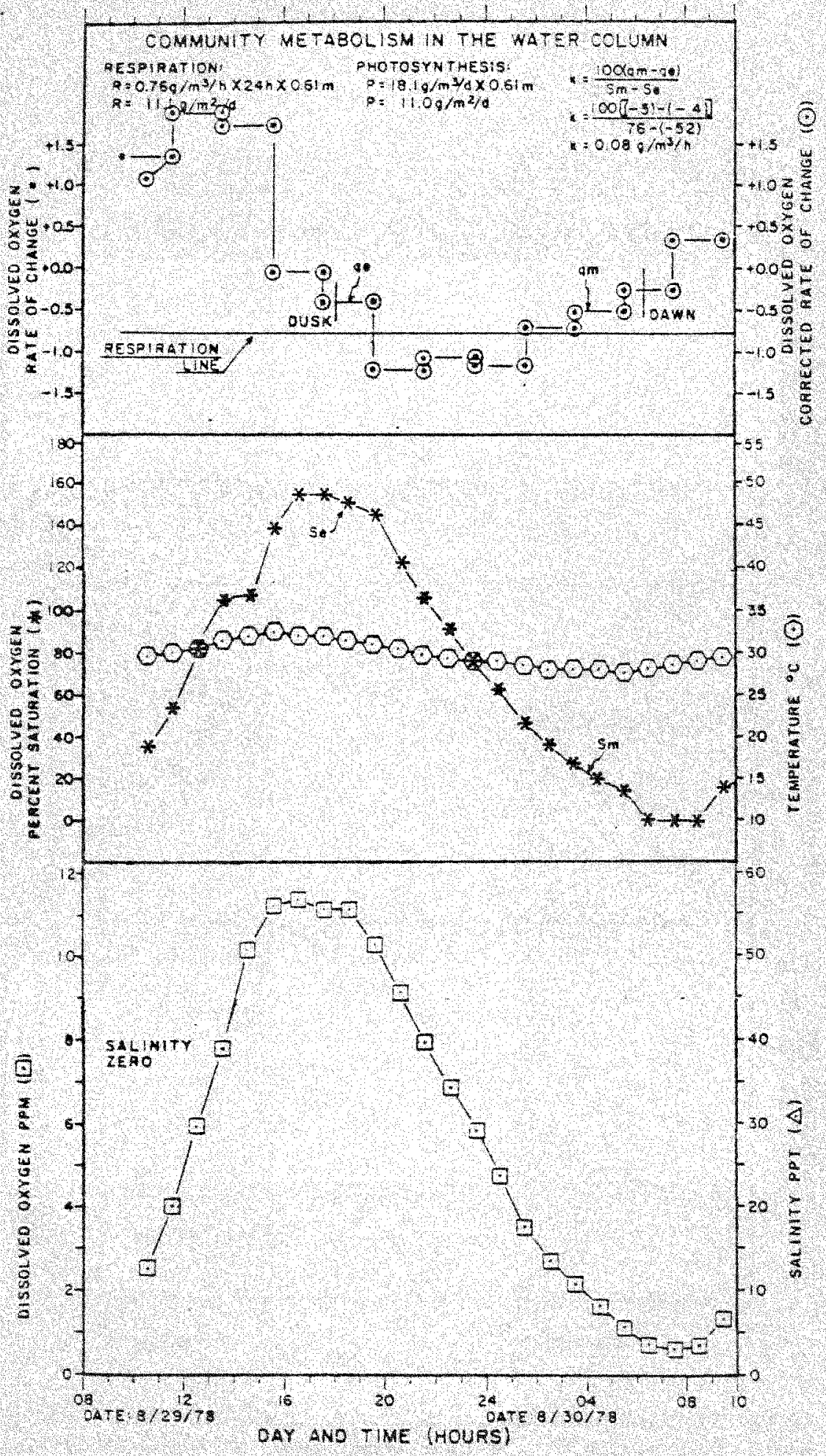

Fig. 42. Community metabolism* in the water column at station A24 in the lake's drainage basin. *Extracted from USEPA data. 


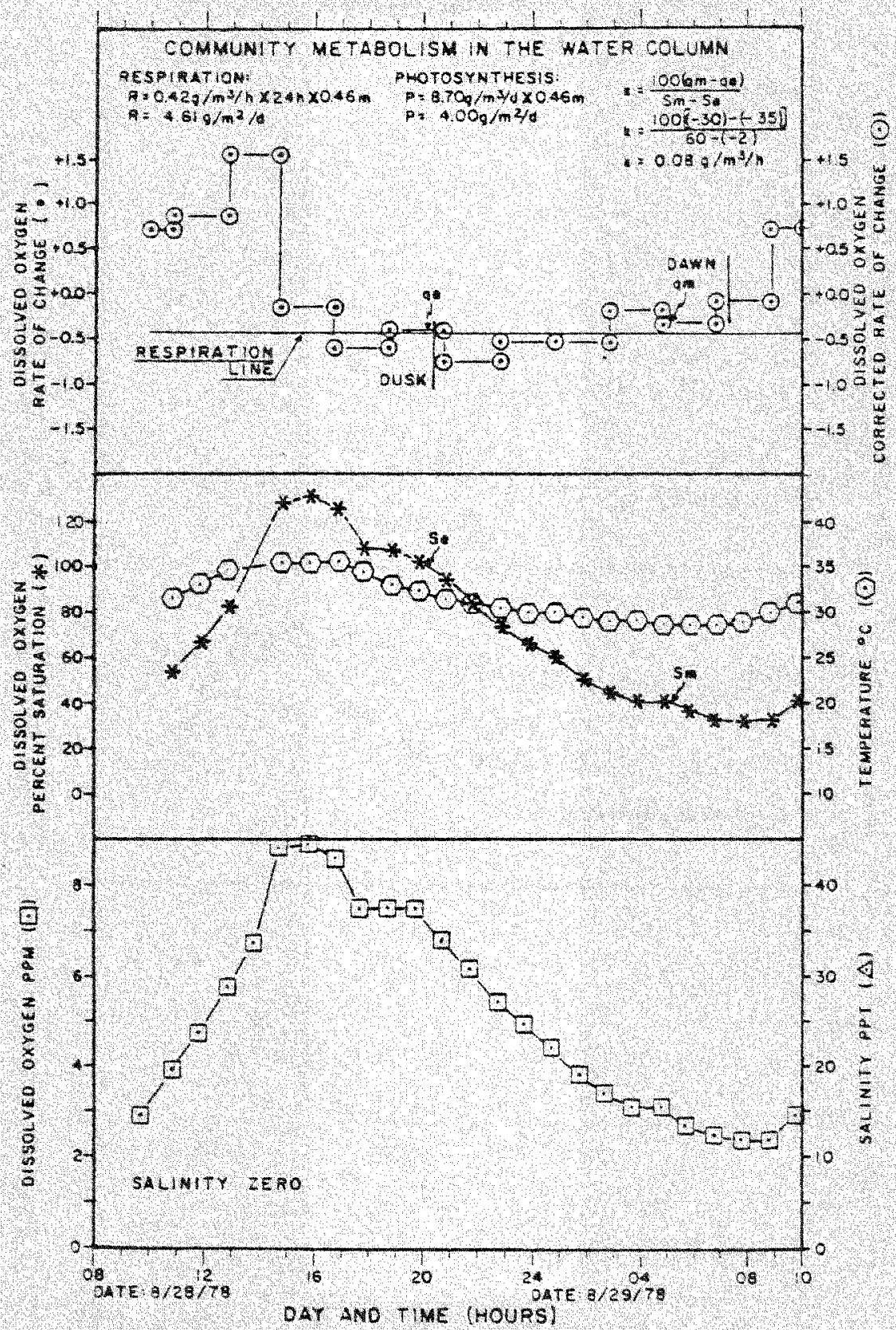

Fig. 43. Community metabolism* in the water column at station B South in the lake's drainage basin. *Extracted from USEPA data. 


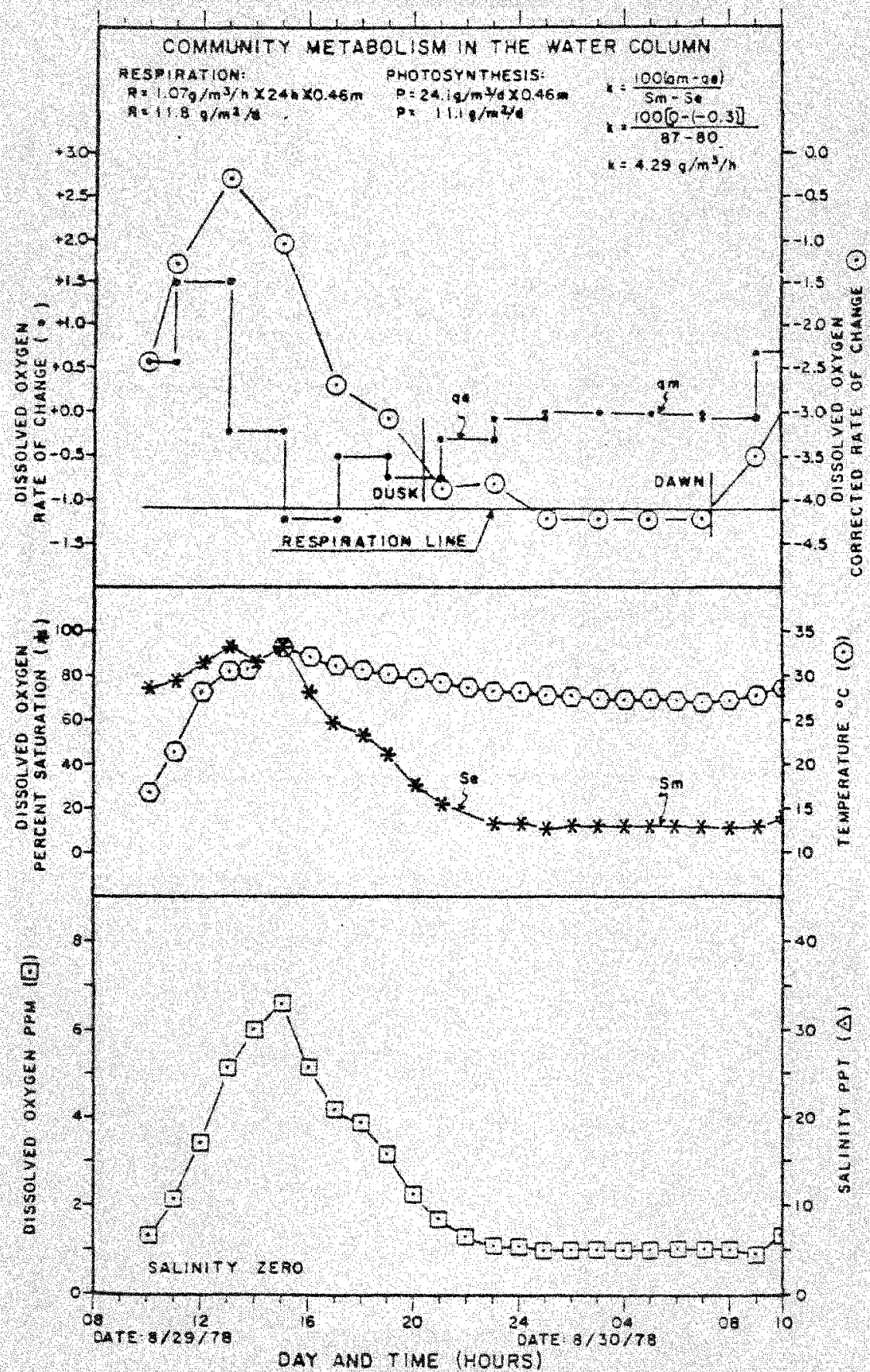

Fig. 44. Community metabolism* in the water column at station $B$ North in the lake's drainage basin. *Extracted from USEPA data. 


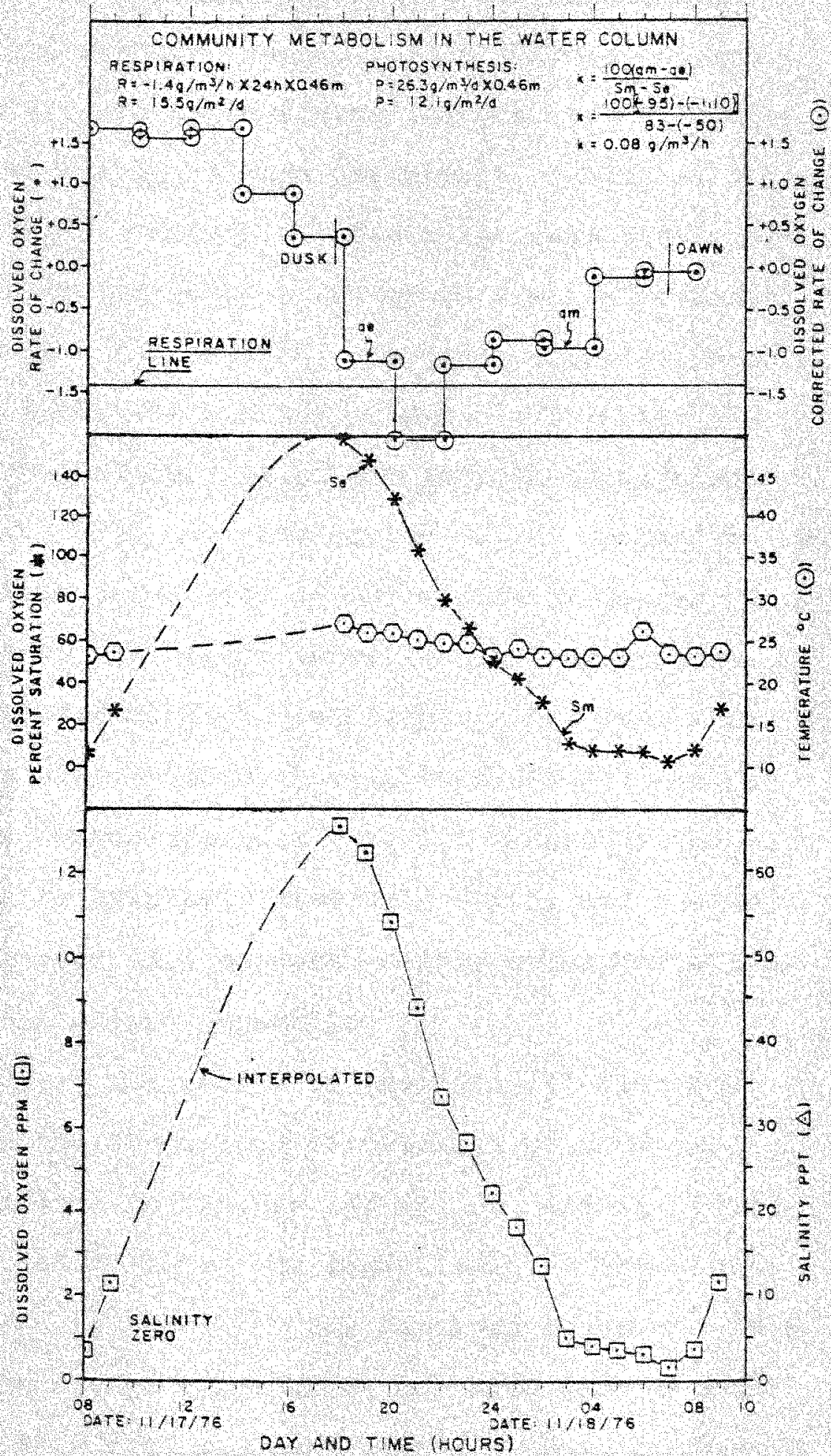

Fig. 45. Commity metabolism in the water column at a Chara pond in the lake's drainage basin. 
layer would have caused respiration to far exceed photosynthesis. This is evident by comparing integration to two depths in the January sample, $1.52 \mathrm{~m}$ (Figure 46) and $2.74 \mathrm{~m}$ (Figure 47) and by observing the results of light and dark bottles (Table 18) and periphyton (Table 19) measurements. Within this $1.0 \mathrm{~m}$ depth increase gross primary production increased by a factor of 2 while respiration increased by a factor of 6 . In other words although quantitatively important production did occur in the vicinity of the chemocline, its effect (oxygen production) was masked by the high net respiration of the monimolimnion. The fact that this production was occurring is further demonstrated in Figure 48 which shows the diurnal production of oxygen at individual depth increments. The bottom of the mixolimnion ( $1.8 \mathrm{~m}$ depth) was maintained near saturation, while the chemocline $(2.1 \mathrm{~m}$ to $2.7 \mathrm{~m}$ depths) was progressively more undersaturated with depth, and the top of the monimolimnion ( $2.7 \mathrm{~m}$ depth) barely evidenced a late afternoon peak in oxygen production.

The results of the series of quarterly productivity measurements in the oxygenated mixolimnion at Lake Marco Shores are presented in Figures $46,49,50$, and 51. For the aforementioned reasons, the lower limit of the mixolimnion was taken as the limit for depth integration. This means that gross primary production may have been as much as two times higher than that calculated. Gross production 


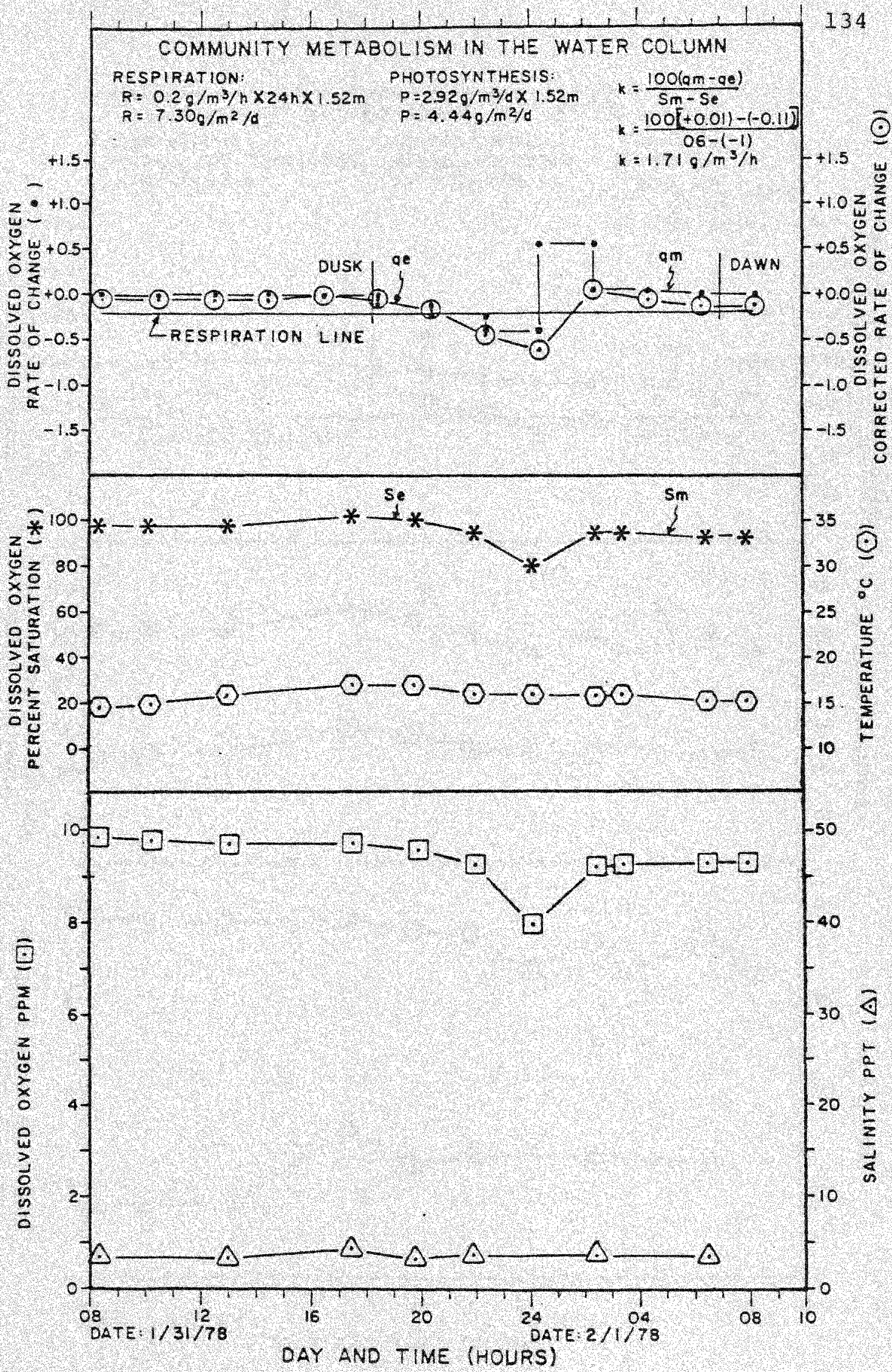

Fig. 46. Comnunity metabolism in the water column at Lake Marco Shores based on an integration to the $1.52 \mathrm{~m}$ depth for the period 31 January - I February, 1978. 


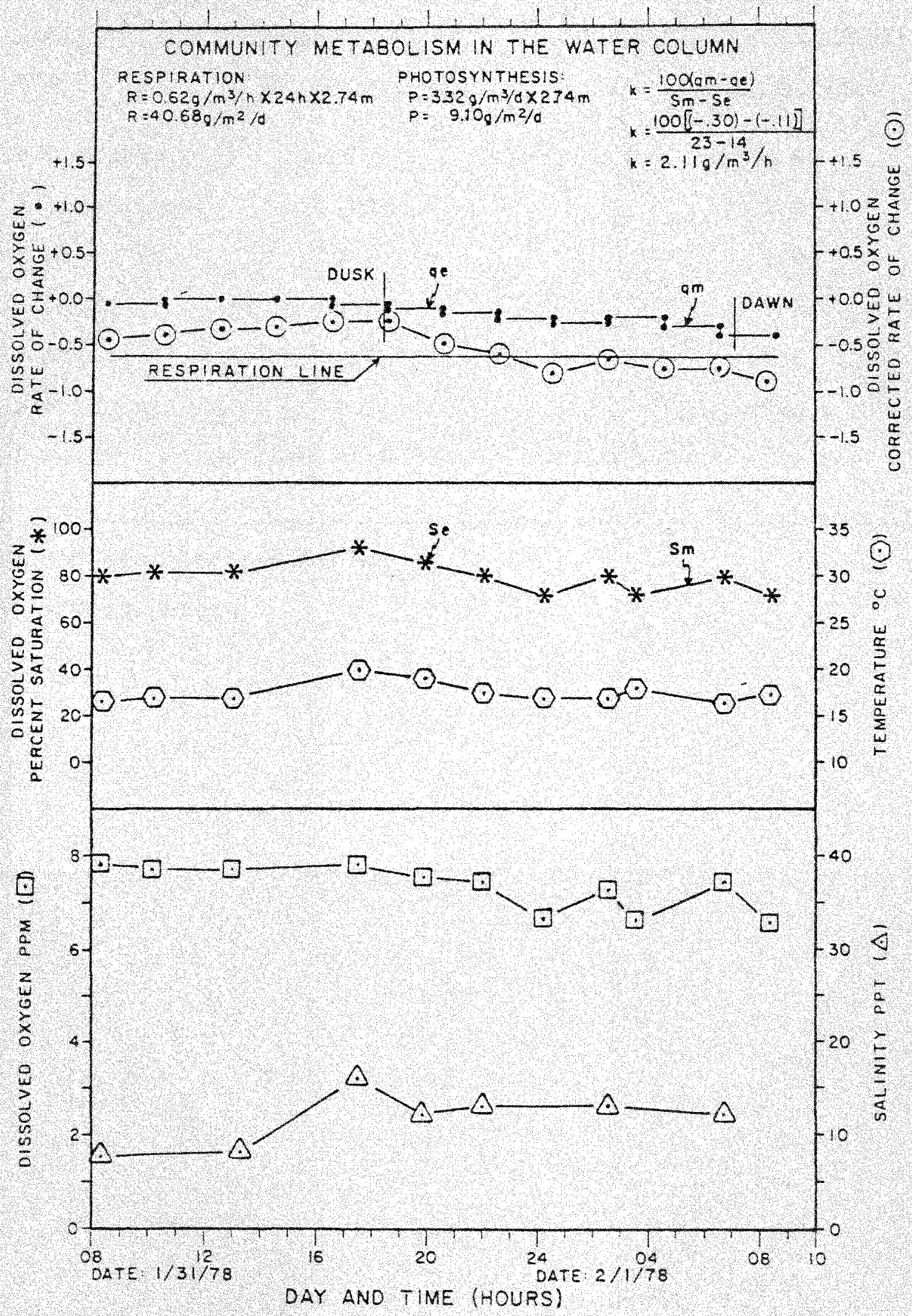

Fig. 47. Community metabolism in the water column at Lake Harco shores based on an integration to the $2.74 \mathrm{~m}$ depth. 
TABLE 18. The results of light and dark bottle productivity measurements in Lake Marco Shores for 1978.

DATE

$\mathrm{GP}\left(\mathrm{gC} / \mathrm{m}^{2} / \mathrm{day}\right)$

$\underline{R\left(g C / m^{2} / d a y\right)}$

$\begin{array}{lrr}13 \text { February } & 3.9 & 2.6 \\ 5 \text { April } & 1.3 & 2.5 \\ 12 \text { May } & 3.3 & 2.9 \\ 6 \text { June } & 5.2 & 3.2 \\ 29 \text { August } & 4.6 & 17.8 \\ 5 \text { October } & 6.1 & 30.6\end{array}$

$\mathrm{GP}=$ Gross Photosynthesis

$\mathrm{R}=$ Respiration 
TABLE 19. The results of a vertical profile of periphyton measurements in Lake Marco Shores.

Chlorophyll $\left(\mathrm{mg} / \mathrm{m}^{2}\right)$

Depth (m)

$\underline{a}$

$\underline{b}$

$\subseteq$

$\begin{array}{rrrr}1.0 & 3.6 & 3.7 & 14.0 \\ 2.0 & 8.3 & 16.5 & 40.9 \\ 3.0 & 0.7 & 0.7 & 3.2 \\ 4.0 & 0.3 & 0.3 & 2.3\end{array}$




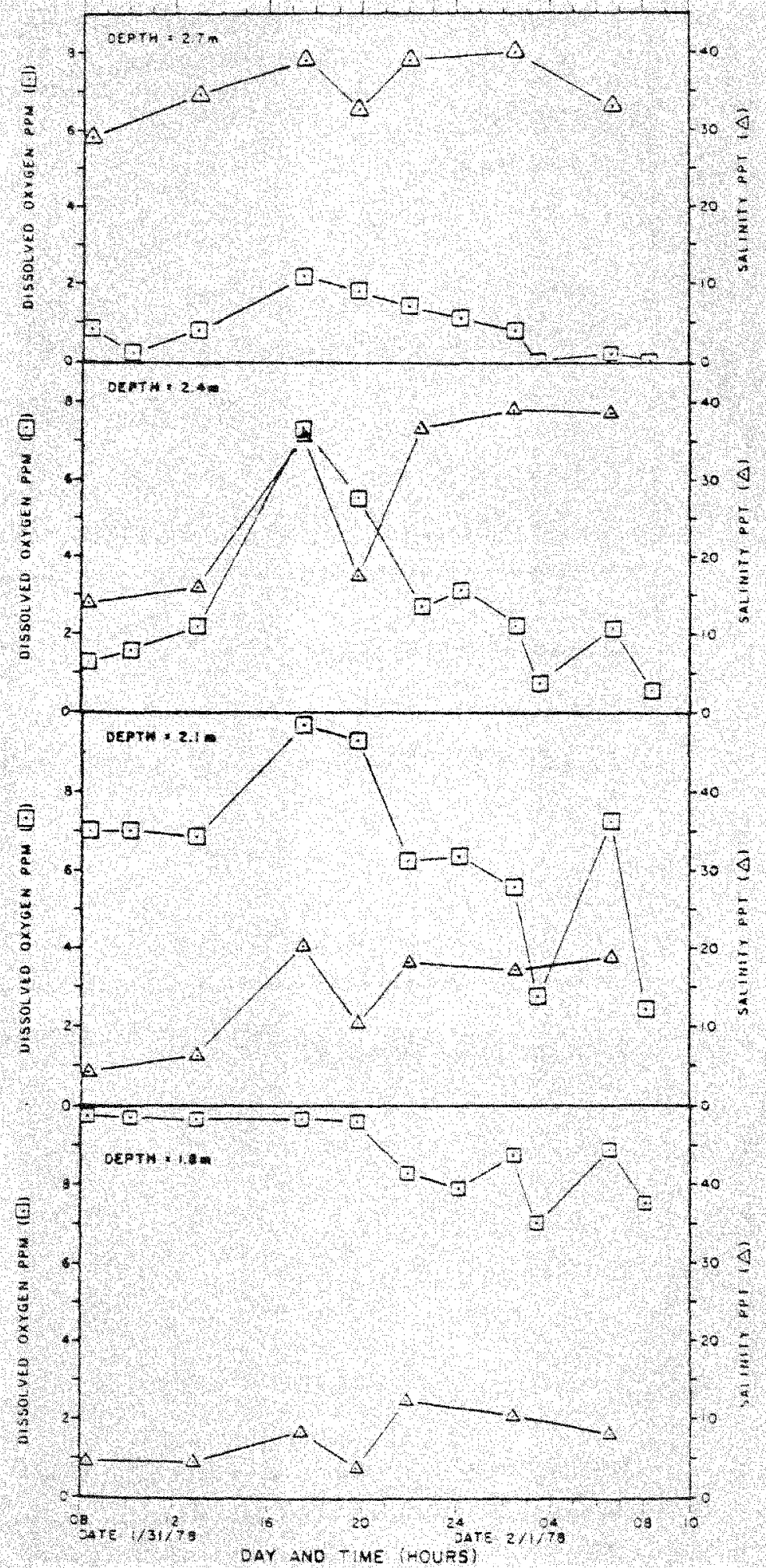

Fig. 48. The aiurnal production of oxygen at selected depths in Lake harco Shores on 31 January, 1973. 


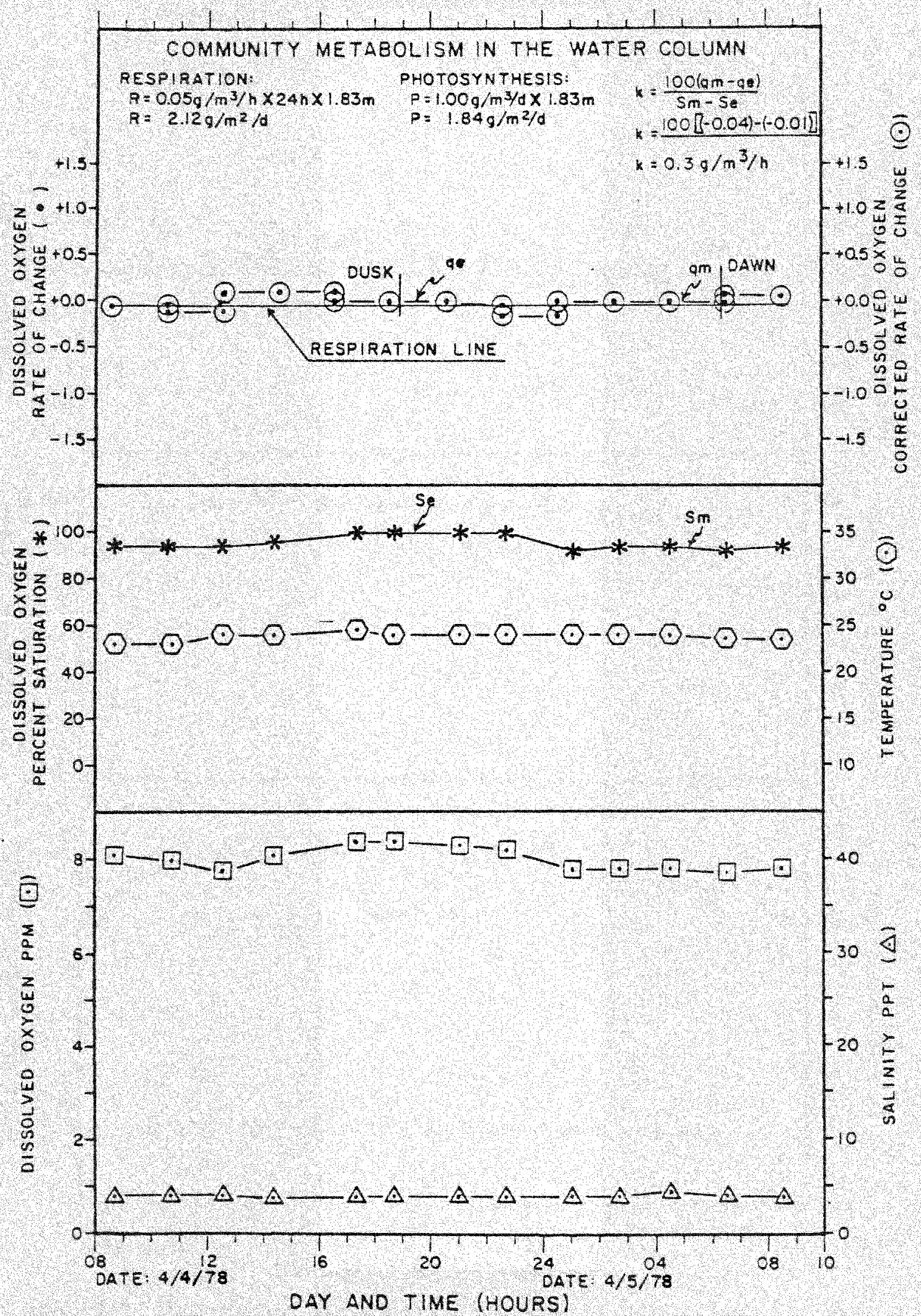

Fig. 49. Community netabolism in the water column at lake Marco Shores for the period 4-5 April, 1978. 


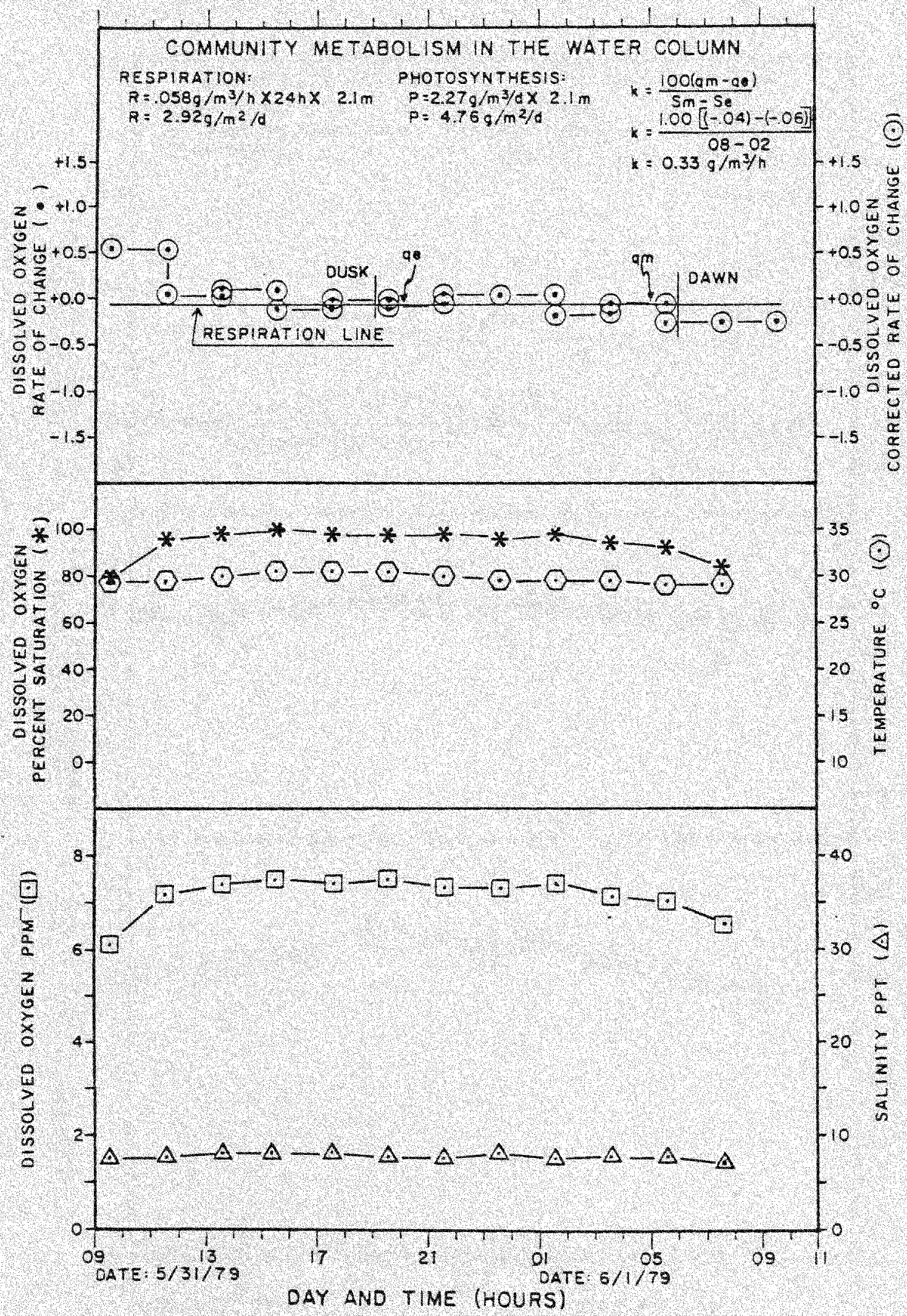

Fig. 50. Community metabolism in the water column at Lake Marco Shores for the period 31 May - 1 June, 1978. 


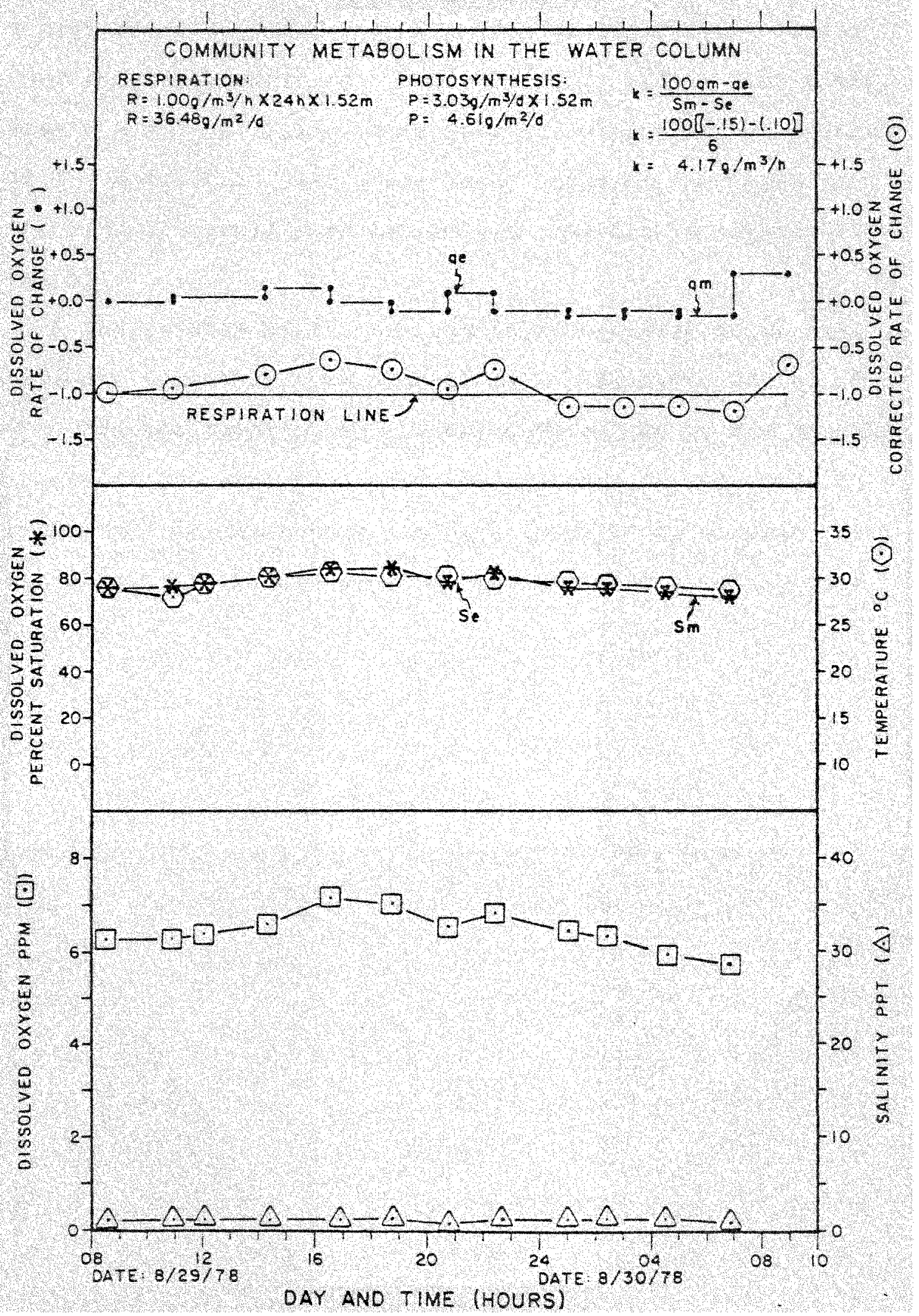

Fig. 51. Community metabolism in the water column at Lake Marco Shores for the period 29-30 August, 1978. 
ranged from a low of $1.84 \mathrm{~g} / \mathrm{m}^{2} /$ day in April (Figure 49 ) to a high of $4.76 \mathrm{~g} / \mathrm{m}^{2} /$ day in May (Figure 50) varying little over an annual cycle $\left(\bar{x}=3.91 \mathrm{~g} / \mathrm{m}^{2} /\right.$ day; s.d. $=1.39 \mathrm{~g} / \mathrm{m}^{2} /$ day; $\mathrm{n}=4)$. Diffusion constants $(\mathrm{k})$ were somewhat greater $(0.3-4.17)$ than in the sheltered areas to the north of the lake. Overall respiration was greatest in August (Figure 51).

The results of the one successful benthic flume experiment suggested that only a small percentage $(0.1 \%)$ of the observed respiration was due respiration of the benthic substrate and organisms contained in it. This provided additional evidence that the high respiration observed in the water column (see page 133) was due to monimolimnionic demands. 


\section{DISCUSSION}

Meromictic lakes have been infrequently observed in North America (Likens, 1967) and only one, Deep Lake, was known to occur in South Florida (Schneider, 1973). Using Hutchinson's (1975a) meromictic classification I would classify Lake Marco Shores as crenogenic because the density difference between the mixolimnion and monimolimnion is maintained by the intrusion of saline ground water at depth. In such lakes the chemocline is formed at the depth determined by the rate of ground water discharge, the density difference between the mixolimnion and the monimolimnion, and the amount of work available for mixing. At Deep Lake, Schneider (1973) has shown that its meromictic stability was chiefly a result of trees shielding the lake from the mixing effects of wind action. At Lake Marco Shores three factors are important. First, salt water intrusion typical for such coastal locations (Klein, 1954) occurs in the area surrounding the lake (Figure 18) and seepage of this water into the lake does occur at depths below the chemocline (cf. Table 7). Fresh water also enters the lake as direct rainfall (Figure 14), as seepage, and as surface runoff. Whereas Downing and Peterka (1978) have shown a relationship between rainfall and lake groundwater seepage in Lake Metigoske (North Dakota), water is not retained above a critical elevation (Figure 17) at Lake Marco Shores and it is discharged as 
surface and groundwater flow to the SR 951 canal. Hence, the chemocline is not driven further downward as the rainy season progresses. Finally, wind induced mixing of the two layers has not occurred over an annual cycle in spite of wind velocities of $80 \mathrm{k} / \mathrm{h}$. The severe restrictions of fetch, length and width are undoubtedly prominent factors in this case.

The vertical physical structure of Lake Marco Shores was similar in many respects to that of other meromictic lakes. Heat retention in the monimolimnion was observed by Anderson (1958a) for Hot Lake, Washington where the green house effect allowed heating of the monimolimnion to $50^{\circ} \mathrm{C}$. He noted that this heat was retained through the winter. The relatively high specific heat capacity of such dense, saline, lower layers has been found to be so effective that the construction of ponds of similar structure has received much recent theoretical and practical attention for use in space heating in cold climates (Rabl and Nielson, 1975; and Zangrondo and Bryant, 1978). The type of thermal stratification exhibited by Lake Marco Shores is unusual, however, when compared to that observed by Brezonik and Shannon (1971) for other Florida lakes.

The seasonal changes in temperature relative to salinity at Lake Marco Shores did not permit a turnover of the water column. It is well known that the density of water at a given salinity is inversely proportional to temperature, 
but that at the $4^{\circ} \mathrm{C}$ point a maximum density is reached. Therefore, winter cooling usually causes a turnover in the water column of many aquatic systems as cooled dense surface water displaces bottom water (Riley and Chester, 1971). At Lake Marco Shores, however, during the times of minimal temperature difference between the mixolimnion and monimolimnion when such cooling might have caused mixing (see April-May and July-September, Figures 20 and 21), the salinity difference between the two layers has been greatest. Furthermore, the thermocline that formed at the interface between the two layers during the remaining months was usually quite pronounced imparting a great degree of stability over an annual cycle. Below this thermocline I found high suspended solids (cf. Table 3) and turbidity (cf. Table 11) relative to the surface layer. These data may indicate an entrainment of suspended materials in the dense lower layer. Ritchie et al. (1978) have shown that when such thermoclines were present in four Mississippi reservoirs a similar increase in suspended solids occurred in the top of the lower layer due to water level regulation in the reservoirs. I have demonstrated a degree of natural water level regulation in Lake Marco Shores (cf. Figure 17) in that the surface layer does not accumulate runoff above a critical elevation of $\sim 0.67 \mathrm{~m} \mathrm{NGVD}$. The lake then may have acted as a settling basin concentrating solids in the monimolimnion. The low magnesium to chloride ratios for surface 
waters discharging from the lake provided further evidence that ground water moved from the surrounding basin through the lake. The $\mathrm{X}$-ray diffraction analysis of deep lake sediments revealed that flocculation of some magnesium occurred in the lake. Riley and Chester (1971) note that the flocculation of clay minerals, such as magnesium calcite, occurs at fresh-salt water boundaries because water is drawn out of clay mineral settling units as the total ionic concentration of the surrounding solution increases. Such a boundary was present in the chemocline of the lake.

The chemical make up of the lake was not unlike that of the surrounding groundwater, but the conditions observed were quite different from other lakes in Collier county and from the Marco Island estuary (Table 20). The saline monimolimnion had at least an order of magnitude greater concentration of $\mathrm{TPO}_{4}, \mathrm{OPO}_{4}$ and $\mathrm{NH}_{3}-\mathrm{N}$ than estuarine water while the mixolimnionic values for the two phosphorus species were more like the levels observed in other freshwater lakes in the county. Likens (1967) and Sorokin and Donato (1975) indicate that a buildup of phosphorus and ammonia in the lower layer of a meromictic lake was to be expected. Active nitrification was also indicated (Ruane and Krinkel, 1978) by the buildup of $\mathrm{NO}_{2}-\mathrm{N}$ in the monimolimnion.

The key to the chemical equilibrium in the lake appeared to be the effect of external sources. Rainfall was 


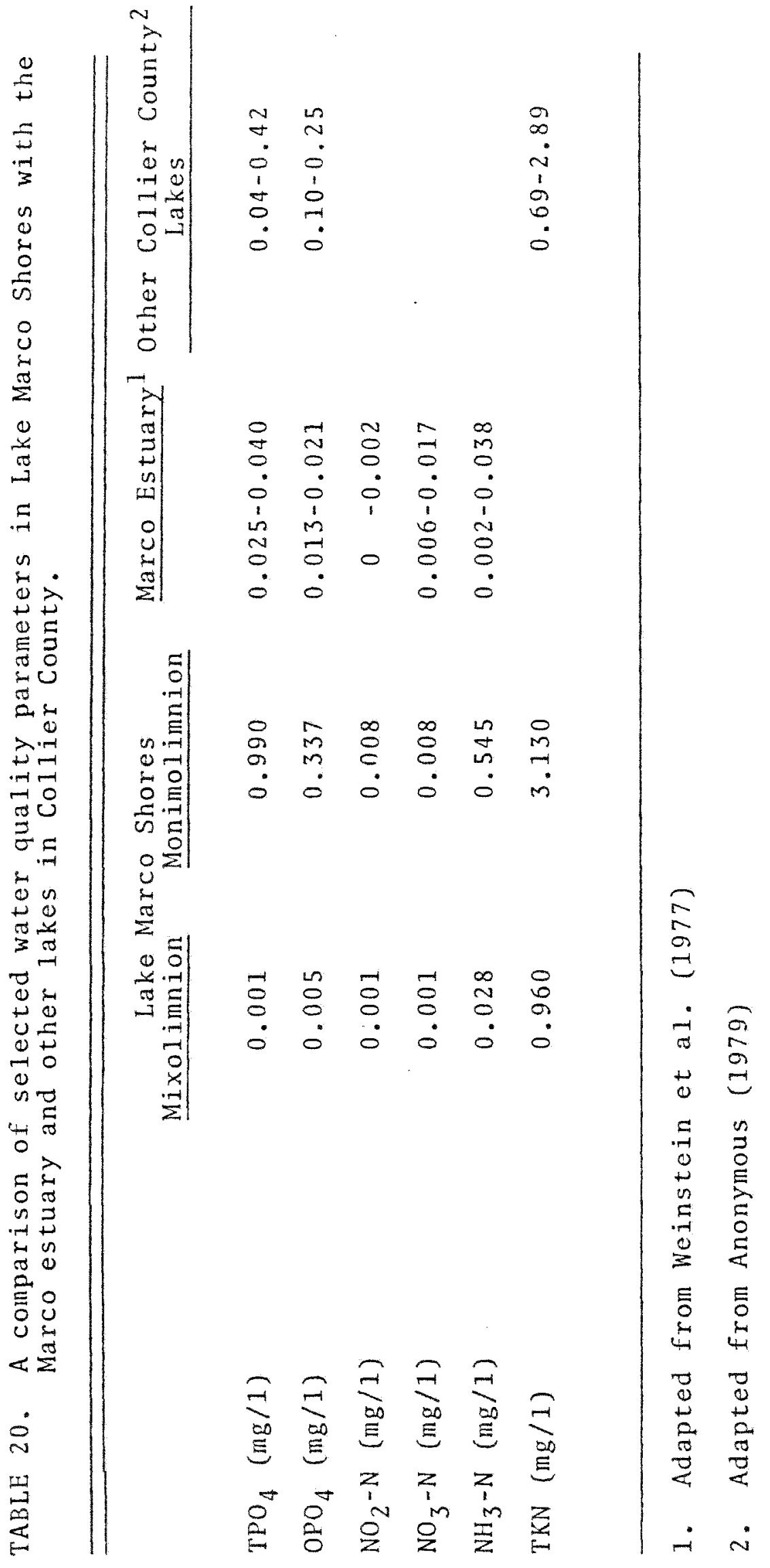


shown to provide direct inputs of $\mathrm{NO}_{3}-\mathrm{N}$ and $\mathrm{TPO}_{4}$ to the lake and presumably also to the marshes of the drainage basin. Groundwater seepage apparently played an even bigger role. Similar results were reported by valiela et al. (1978) who showed that groundwater supplied twenty times the amount of essential nutrients to a Massachusetts salt marsh when compared to local rainfall. The standing crop data (Tables 1 and 12) for Lake Marco Shores and its drainage basin indicated that there was considerable emergent and submerged macrophytic production in some portions of the basin. The resulting production apparently was supported by such rain and groundwater subsidies. However, the high respiration (relative to production) measured by the metabolism studies in the water surrounding this emergent vegetation indicated that most of this production was being metabolized in situ. Turner (1978) has observed similar oxygen depletion in a Georgia salt marsh plankton assemblage. He defined this community as being heterotrophic because of the importance of leached, dissolved organic carbon from the spartina present.

The concentration of TKN in Lake Marco Shores peaked during the April-September rainy season (cf. Figures 17 and 26). This relationship may have been due to the flushing of the marshes in the lake's drainage basin. In studying the water chemistry relationships between the marshlands and estuarine portions of the Big Cypress Swamp 
in Collier County Carter et al. (1973) reported that the concentration of TKN, tannin and lignin-like compounds at stations which were transitional between the marshes and estuary increased during the June-November rainy period as a result of the flushing of upland swamps. Schneider (1973) also noted that increases in the concentration of dissolved organic matter followed the pattern of rainfall at Deep Lake in Collier County. He suggested that these changes were due to runoff from swamps surrounding the lake. Similarly, the results of Daddio and Van de Kreeke (1979) indicate that TOC discharged via runoff (and groundwater seepage) from the lake and its drainage basin was also related to the local rainfall pattern. However, a direct response was dampened by the ability of the basin (and presumably the lake) to absorb and hold the "first flush" of water from the marshes of the drainage basin at the beginning of the rainy season.

The Marco estuary is seasonally hypersaline (Weinstein et al. 1977) and although the intrusion of groundwater at depth in the lake has been demonstrated, the hypersaline condition that has been observed in the lake and in the surrounding watershed may have been augmented by a combination of evaporation of storm tide waters (e.g. Hurricane Donna which innundated the area in 1960) and by the physiological processes of the plant populations present. Smart and Barko (1978) have shown that some of the plant 
species present in the area (e.g. Epartine and pistichlis) are not only capable of salt secretion but are also able to exclude ions resulting in increased sediment salinity. The productivity of Lake Marco Shores was $10 \mathrm{w}$ and if its trophic state were classified with other Florida lakes according to the criteria of Brezonik and Shannon (1971), it probably would fall in the oligotrophic category. Frey (1967). Jackson and Dence (1958) and Taylor (1960) have reported similar results for other meromictic lakes which were judged to be unproductive as a result of the monimolimnion serving as a nutrient trap or sink. My observations of high production at the interface between the mixolimnion and monimolimnion (i.e. metabolism studies, chlorophylla and TOC quantities) at Lake Marco Shores may be explained by the availability of these production stimulating nutrients at the interface.

Although I performed no bacterial studies there might be an additional kind of production occurring at the interface. I found that at least $5 \frac{3}{3}$ of the incident solar radiation penetrated to the top of this layer (cE. Figure 19), that $\mathrm{H}_{2} \mathrm{~S}$ was always present in the monimolimnion and that high sulfate concentrations were also available in this zone. Sorokin and Donato (1975) have confimed that high autotrophic production can occur at the interface between the oxygenated layer and the hydzogen sulfide zone in a meromictic lake. They observed that whereas phytoplankton photosynthesis was active in the upper layer, 
it was replaced by the sulfur bacterium, chromatium, in the chemocline. The occurrence of such bacteria at the tof of the monimolimnion in meromictic lakes is common (Anderson, 1958b), and all of the requirements for such production (i.e. $\mathrm{H}_{2} \mathrm{~S}$ and adequate light) are available at the top of the monimolimnion in Lake Marco Shores. Bacterial plates of one milion or more celis per ml have formed at the top of monimolimnion in other meromictic lakes imparting rosy, greenish or purplish tinges to the water depending on the type of bacteria present (Frey, 1967). Sorokin (1965) has observed that copepods and protozoa have their maximum population densities near the bottom of the mixolimnion, just above or somewhat overlapping the plate of photosynthetic and chemosynthetic bacteria. He showed that during daylight hours the $\mathrm{H}_{2} \mathrm{~S}$ content of the chemocline can in fact become perceptively reduced due to the photosynthetic uptake by purple sulfur bacteria allowing the zooplanktors to move down into the bacterial zone to feed. Most of the larger zooplanktors of Lake Marco Shores were also concentrated at the interface between the mixolimnion and monimolimnion (cf. Figures $34,35,37$ and 39) and this probably indicated a concentrated food source.

While the oxidation of a variety of sulfur compounds by anaerobic microorganisms can only be postulated for Lake Marco Shores there was some circunstantial avidence 
of the presence of reducing anaerobic bacteria in the lake monimolimnion. All of the equipment which was lowered into this layer became coated with a black, filmy substance. This was also true for the insides of polyethylene containers used to store sample water from this layer. Doetsch and Cook (1974) have noted that the Black Sea got its name from sulfate reducing bacteria (Desulfovibro) which produced black metal sulfides (generally iron sulfide). Desulfovibro appears suited for life in the monimolimnion. This group of bacteria thrives under a variety of environmental conditions and thermophilic and halophilic forms have been described (Doetsch and Cook, 1974). Sulfate levels were quite high and iron concentrations (Table 10) showed a general decrease in the vicinity of the monimolimnion. Although Batley and Gardner (1978) have shown that a general increase in metals could be associated with an increase in colloidal matter such as occurred in the lake below the mixolimnion, it probably was just symptomatic of the fact that the lower layer in the lake was made up of sea water. From the cursory review of microplankton distribution in Lake Marco Shores it appears that the flagellates occupy an important niche in the chemocline and top of the monimolimnion. Within this group the Euglenophyta are known to be generally limited to waters which are relatively rich in organic matter or contain abundant bacteria (Hutchinson, 1967). Thus, they and their relatives, together with the 
bacteria, may have provided an important food link between the zooplanktors (i.e. rotifers and copepods) of the mixolimnion and the high nutrient concentrations of the monimolimnion. The oxidation of $\mathrm{H}_{2} \mathrm{~S}$ even may not have been a prerequisite for the occurrence of zooplankton at this interface. Sorokin and Donato (1975) noted that ciliates were the main bacterial feeders in a Sicilian meromictic lake, and that they were found in areas where the $\mathrm{H}_{2} \mathrm{~S}$ concentration reached $40 \mathrm{mg} / 1$. Ruppia appeared favored for life in the littoral zone of the lake by its range of salinity tolerance $(2.1-34.3 \%$ ), its preferred growing season temperature range $\left(18.5-30^{\circ} \mathrm{C}\right)$ and its preferred growing depth - $0.6 \mathrm{~m}$ (Joanen and Glasgow, 1965). This submerged macrophyte, together with the litterfall of shoreline mangroves, appeared to support a predominantly detrital feeding macrobenthic assemblage. The polychaete, Laeonereis culveri (Webster), a detrital feeder, was found in substantial quantities $(2,739$ individuals $\left./ \mathrm{m}^{2}\right)$ in the lake's shallow $(<0.6 \mathrm{~m}$ ) littoral zone. These densities were much higher than those found in other Florida salt marshes. Subrahmanyar et al. (1976) found $\underline{L}$. culveri densities only as high as $26 / \mathrm{m}^{2}$ in the Wakulla and St. Mark's River marshes. Hartman (1951) observed that Laeonereis was the most abundant burrowing form on the salt flats of Aransas refuge and that it was 
resistant to the types of low salinity and temporary drought that it would have to withstand in the littoral zone of Lake Marco Shores.

The minute $(2.5 \mathrm{~mm})$ brackish water assimineid gastropod is largely restricted to shallow depths $(0.2 \mathrm{~m})$ and is most abundant where Ruppia occurs. This species is also presumed to feed on detritus since Kofoed (1975) has found that a related snail (Hydrobia) can assimilate $34 \%$ of its nutritional requirements from detritus. Mysid shrimps, also collected in the lake, are similarly known to make use of detrital material (Foulds and Mann, 1978). The false mussel, Mytilopsis leucophaeata (Conrad), is another brackish water species (Abbott, 1974), and it appears to have been responsible for the June-August peak in veliger larvae abundance at the lake (Figure 39). Contrary to the findings of Odum (1971) in Florida's North River estuary, the adults were most abundant at Lake Marco Shores in the october-December period. He reports that this filter feeder was abundant in the upper reaches of the estuary during the summer months, but population declines during the winter dry season were observed. The life stages of this species appeared to be vertically separated in Lake Marco Shores with the larvae seeking out the conditions of the chemocline and the adults settling in the mixolimnion.

The razor clam, Tagelus plebeius, seemed well able to cope with the conditions in Lake Marco Shores until the 
rainy season (June). With the drawdown of lake waters at the end of the dry season the center of its distribution was exposed, and it subsequently fell prey to birds and raccoons. Perry and Schwengle (1955) reported Tagelus plebeius from moderate depths in the Gulf littoral zone at Sanibel to the north of the study area, and Abbott (1968) noted that it was a rapid burrower living in muddy areas near brackish water. This clam was found by Taylor et al. (1970) in what they considered particularly high densities $\left(>300 / \mathrm{m}^{2}\right)$ at shallow $(0.3 \mathrm{~m}-0.7 \mathrm{~m})$, low salinity $(0.74-$ $3.69 \%$ stations in Boca Ciega Bay while Subrahmanyar et al. (1976) found that it extended into Juncus marshes (salinities: 10-20 \% $/ 00$ ).

The only other abundant benthic invertebrates were chironomid midge larvae. This herbivorous group is known to tolerate waters where low oxygen conditions prevail (Pennak, 1953). In Lake Marco Shores the larvae were found throughout the mixolimnion and chemocline, but as with all of the other species none was found below a depth of 2.5 meters. It is not uncommon for benthic organisms present in meromictic lakes to be concentrated near the top of the monimolimnion. Midge larvae are usually dominant, and are common even in the monimolimnion of the more severly chemically stratified lakes where there may be no benthos at all (Frey, 1967).

The area around Lake Marco Shores has been considered 
brackish, but with the recent (i.e. 1972) impoundment of fresh water by construction activities it has become more fresh. I found that several marine species (e.g. Laeonereis and Tagelus) have exploited this condition and appear in greater numbers in Lake Marco Shores than they do in an assortment of natural brackish water habitats that other authors have surveyed. These species are presumed to have invaded the lake from the preexisting brackish marshes during the construction phase via larval settlement. It is well known that brackish waters are poor in diversity when compared with similar marine or fresh water regions (Remaine and Schliepier, 1971). However, certain marine mollusks (e.g. Rangia cuneata, Grey) are known to be quite capable of exploiting the estuarine upper reaches where low salinities are both physiologically and ecologically optimal (Hopkins et al. 1973). Such seems to be the case for some of the species in the lake. The Tagelus population disappeared from the littoral zone during the June-December period (cf. Table 16). Castagna and Chanley (1973) examined the salinity tolerances of a number of marine bivalves including Tagelus plebeius. They were able to culture Tagelus larvae at salinities of $20 \%$ and $30 \%$, and they showed that up to $33 \%$ of the adults could survive direct transfer from areas of intermediate salinity $(20 \%)$ to waters of $2.5 \%$ such as might have occurred during the construction of the lake (cf. Figure 3). They also noted that populations 
suffered considerable stress in salinities below $10 \%$ This was not the case in Lake Marco shores where peak abundance occurred at salinities of less than $5 \%$ (cf. Table 16 and Figure 30).

Poirrier and Mulino (1977) on the other hand have shown that sudden influxes of fresh water, while eliminating essentially marine species, do not greatly affect brackish water forms. It must be concluded that seed populations of Tagelus and many of its associates which inhabited the marshes prior to the construction of the lake, must have found conditions in the lake adequate to complete their respective life cycles. 


\section{SUMMARY}

A Iimnological description of Lake Marco Shores, Collier County, Florida was conducted from October, 1976 through March, 1979. This manmade lake was located close to the estuary and was long $(344 \mathrm{~m})$ in relation to its breadth $(237.9 \mathrm{~m})$. A large percentage $(83)$ of the volume of the lake occupied a cryptodepression.

1. The lake was shown to be meromictic, with a stable vertical density structure over an annual cycle.

2. The lower layer evidenced accumulated nutrients relative to the top layer which was nutrient poor and always anaerobic. The upper layer was always aerobic.

3. The water column as a whole, had no net production over an annual cycle, but analysis of discreet depth intervals between the two main layers did indicate that production was occurring in this narrow zone.

4. The meromictic condition was shown to be maintained by seepage of ground water into the lake at depths and by the surface input of rainfall and runoff.

5. The vertical chemical and physical structure of the surrounding ground water was shown to be similar to that of the lake, but not like that of either the estuary or inland areas of Collier county.

6. The flora and fauna of the lake had brackish water affinities with marine and fresh water forms finding conditions in the lake and surrounding watershed suitable 
for maintenance and reproduction. The benthos and plankton were shown to orient vertically relative to the lake's strata. A great concentration of zooplankton and phytoplankton was seen at the interface between the two layers.

7. The low production and nutrient concentrations and high transparency of the upper layer indicate that Lake Marco Shores is oligotrophic. 


\section{GLOSSARY}

Allochthonous - not formed in situ.

Autochthonous - formed in situ.

Chemocline - the boundary between the mixolimnion and the monimolimnion in a meromictic lake.

Clinograde - an extreme vertical distributional difference for a measured parameter.

Crenogenic - a type of meromixis that results from the deIivery by springs of dense saline water into the depths of the lake.

Cryptodepression - the depth of the bottom of a lake that is below modern mean sea level.

Halocline - the plane of maximum rate of change of salinity.

Homiothermy - a condition in which there is no temperature difference between the surface and bottom in a lake.

Meromictic - a lake in which some water remains partly or wholely unmixed with the main water mass during part of the annual cycle.

Mesothermy - the condition when there is a maximum is a temperature curve.

Monimolimnion - the perenially stagnant deep layer of a meromictic lake.

Mixolimnion - that part of a meromictic lake where free circulation periodically can occur.

Negative aerotaxis - repelled by the presence of oxygen.

Orthograde - a vertically uniform distribution of a measured parameter.

Poikilothermy - a condition where one or more temperature maxima coexists with one or more minima.

Positive phototaxis - attracted toward light.

Thermocline - the plane of maximum rate of change of temperature. 
$x$-ray diffraction - use of the measured angles and intensities of scattered or diffracted rays of a given wavelength to determine the spacing of regularly repeating atomic or molicular units in crystals. 


\section{LITERATURE CITED}

Abbott, R.T. 1968. Seashells of North America. Golden Press. New York. 250 pp.

1974. American Seashells, 2nd. edition. Van Nostrand Reinhold Co., New York. $663 \mathrm{pp}$.

Anderson, G.C. 1958a. Some limnological features of a shallow saline meromictic lake. Iimnology and Oceanography. Vol. 3: 259-270.

1958b. Seasonal characteristics of two saline lakes in washington. Limnology and Oceanography. Vol. 3 : 51-68.

Anonymous, 1975b. Shore protection manual. U.S. Army Coastal Engineering Research Center. Vol. 1, Ch. 3. pp. 3-29 to 3-52.

Appleby, B.J. and J.M. Hatcher. 1974. Water Quality Monitoring. In: Progress Report to the Marco Applied Marine Ecology Station. Dec. 1974. pp. 8-27.

Batchelor, B. and A.W. Lawrence. 1978. Autotrophic denitrification using elemental sulphur. Journal Water Pollution Contr. Fed. pp. 1986-2001.

Batley, G.E. and D. Gardner. 1978. A study of copper, lead and cadmium speciation in some estuarine waters and coastal marine waters. Estuarine and Coastal Marine Science. Vol. $7: \quad 59-70$.

Black, Crow, and Eidsness. 1973. Water management study for Water Management District 6, Collier County, Florida. Report to Collier County Water Management Advisory Board. Black, Crow and Eidsness, Inc. Gainsville. pp I-I to 6-8.

Bloom, S.A., J.L. Simon and V.D. Hunter. 1972. Animal-sediment relations and community analysis of a Florida estuary. Mar. Biology 13:43-56.

Brezonik, P.L. and E.E. Shannon. 1971. Trophic state of lakes in north central Florida. Publ. No. 13. Water Resources Res. Center. Dept. of Environmental Eng. Sci. University of Florida. Gainsville. $102 \mathrm{pp}$.

Brockmann, F.W. 1974. Seasonality of fishes in a south Florida brackish canal. Fla. Sci. $37(2): 65-70$. 
Browder, J.A. 1978. A modeling study of water, wetlands and woodstorks. Wading birds, Res. Rept. No. 7. National Audobon Soc. pp. 325-346.

Carpenter, J.H. 1973. Chemical observations of the water in the Marco Island and Naples areas. Rept. to the Deltona Corp. Rosenstiel School of Mar. and Atmos. Sci. University of Miami. $60 \mathrm{pp}$.

Carter, M.R., L.A. Burns, T.R. Cavinder, K.R. Dugger, P.L. Fore, D.B. Hicks, H.L. Revels and T.W. Schmidt. 1973. Ecosystems analysis of the Big Cypress Swamp and Estuaries. USEPA Region IV. Surveillance and Analysis Div. S. Fla. Ecolog. Study. pp. I-1 to XIX-119.

Castagna, M. and P. Chanley, 1973. Salinity tolerance of some marine bivalves from inshore and estuarine environments in Virginia waters on the western Midatlantic Coast. Malacologia $12(1): 47-96$.

Clausen, C.J., A.D. Cohen, C. Emiliani, J.A. Holman and J.J. Stipp. 1979. Little Salt Spring, Florida: A unique underwater site. Science 203(4381):609-614.

Courtney, C.M., J.M. Hatcher and P.G. Genoa. 1977. The occurrence of Tagelus plebeius in a manmade brackish water lake with comments on its associates. Bull. Amer. Malacolog. Union, 1977. pp. 68-75.

Daddio, E. and J. Van de Kreeke. 1979. Flux of dissolved organic carbon from a wetland area near Marco Island, Florida. Rept. to the Deltona Corp. Rosenstiel School of Marine and Atmospheric Sciences. Univ. of Miami. $82 \mathrm{pp}$.

Doetsch, R.N. and T.M. Cook. 1974. Introduction to Bacteria and Their Ecobiology. University Park Press. Baltimore. $360 \mathrm{pp}$.

Downing, J.A. and J.J. Peterka. 1978. Relationship of rainfall and lake groundwater seepage. Limnology and oceanography $23(4): 821-825$.

Fell, J.W., R.C. Cefalu, I.M. Master, and A.S. Tallman. 1974. Microgial activities in the mangrove (Rhizophora mangle) leaf detrital system. In: Proceedings of International Symposium on Biology and Management of Mangroves. Honolulu, Vol. II. PP. 661-679.

Finan, D.S. 1979. A standing crop determination for the fishes of Lake Marco Shores, Marco Island, Florida. Rept. to the Deltona Corp. pp. 1-8. 
Foulds, J.B. and R.H. Mann. 1978. Cellulose digestion in Mysis stenolepsis and its ecological implications. Limnology and Oceanography. 23(4):760-766.

Frey, P.G. 1967. Biological characteristics of meromictic lakes. In: Some aspects of meromixis. D.F. Jackson, editor. Dept. Civil Eng. Syracuse Univ. Dec. 1967. pp. 65-95.

Gaarder, T. and H.H. Gran. 1927. Investigations of the production of plankton in Oslo Fjord. Rapp. Process-Verbaux, Reunions Cons. Perma. Int. Explo. Mer. Vol. 42:1.

Hall, C.A. 1971. Migration and metabolism is a stream ecosystem: North Carolina Univ. Dept. Zoology and Dept. Environmental Sc. and Eng. Rept. Vol. 49, 243 pp.

Hartman, D. 1951. The littoral annelids of the Gulf of Mexico, Publ. Inst. Mar. Sci. 2(1):7-124.

Heald, E.J. 1971. The production or organic detritus in a South Florida Estuary. Sea Grant Technical Bulletin 6. No. 4, Univ. of Miami. 120 pp.

Hicks, D.B. and L.A. Burns. 1974. Mangrove metabolic response to alterations of natural freshwater drainage to southern Florida estuaries. In: Proceedings of International Symposium on Biology and Management of Mangroves. Honolulu. Vol I:238-265.

Hopkins, S.H., J.W. Anderson, and K. Howath. 1973. The Brackish water Clam, Rangia cuneata, as Indicator of Ecological Effects of Salinity Changes in Coastal Waters. Dept. Biol. Res. Found., Texas A and M Univ. College Sta. Contract No. DACW39-71-C-0007. Sponsored by: Office of Chief of Engineers. U.S.Army. pp. 1-250.

Hunt, B.P. 1958. Limnetic distribution of Chaoborus larvae in a deep Florida lake (Diptera: Culicidae) Florida Entomologist, Vol. 4:111-116.

Hutchinson, G.F. 1967. A treatise on limnology. Vol. (2). Introduction to lake biology and limnoplankton. John Wiley and Sons. New York. $1115 \mathrm{pp}$.

1975a. A treatise on limnology. Vol. (1) part (1). Geography and physics of lakes. John wiley and Sons. New York. 540 pp.

1975b. A treatise on limnology. Vol. (1) part (2). Chemistry of lakes. John Wiley and Sons. New York. pp. 541-1015. 
Jackson, D.F. and W.A. Dence. 1958. Primary productivity in a dichothermic lake. Amer. Midl. Nat., Vol.55:511517 .

Joanen, T. and I.L. Glasgow. 1965. Factors influencing the establisment of widgeongrass stands in Louisianna. In: Proc. of the 19th annual conf. of the Southeastern Assoc. of Game and Fish Com. pp. 78-92.

Johnsson, J. 1946. Termisk-hydrologiska studier i sjön klammingen. Geogr. Ann. Stockh. Vol. 28:1-154.

Johnsson, H. 1949. Wind currents in Lake Klammingen. Gen. Ass. Int. Hydrol. Sci., I.Trav. Comm. Potamol. Limnol., 369-372.

Kimball, M.C. and H.J. Teas. 1974. Nitrogen fixation in mangrove areas of southern Florida. In: Proceedings of International Symposium on Biology and Management of Mangroves. Honolulu. Vol. II pp. 654-660.

King, C.A.M. 1963. An introduction to oceanography. McGraw Hill Book Co., Inc. New York. 337 pp.

Klein, H. 1954. Groundwater resources of the Naples area, Collier County, Florida. Rept. No. 1l. Water Res. Study. U.S.G.S. Tallahassee, Fla. 64 pp.

Kofoed, L.H. 1975. The feeding biology of Hydrobia ventrosa. 2. Allocation of the components of the carbon budget and the significance of the secretion of dissolved organic material. J. Exp. Mar. Biol. Ecol. Vol. 19:243-256.

Lee, D.R. 1977. A device for measuring seepage flux in lakes and estuaries. Limnology and Oceanography. Vo1. 22:140147.

Leighty, R.G. 1954. Soil survey (detailed reconnaissance) of Collier County, Florida, Series 1942, No. 8, U.S. Dept. of Agric, and Fla. Agric. Exp. Sta. $72 \mathrm{pp}$.

Likens, G.E. 1967. Some chemical characteristics of meromictic lakes in North America. In: Some aspects of meromixis. D.F. Jackson, editor. Dept. Civil Eng. Syracuse Univ. Dec. 1967. pp. 19-63.

Lugo, A.E. and S.C. Snedaker. 1974. Properties of a mangrove forest in southern Florida. In: Proceedings of International Symposium on Biology and Management of Mangroves. Honolulu. Vol. II pp. 654-660. 
Miller, P.C. 1974. Simulation of water relations and net photosynthesis in mangroves in southern Florida. In: Proceedings of International Symposium on Biology and Management of Mangroves. Honolulu. Vol. II pp. 615-631.

Nielson, R.S. 1953. Apparatus and methods for the collection of attached materials in lakes. Progressive Fish Culturist 15 (2):87-89.

N.O.A.A. 1975. National Ocean Survey Nautical Charter. U.S. Dept. Commerce. Wash. D.C.

Odum, H.T. and C.M. Hoskin. 1958. Comparative studies on the metabolism of marine waters. Texas Univ. Inst. Mar. Sci. Publ. Vol. 5:15-46.

Odum, W.E. 1971. Pathways of energy flow in a South Florida Estuary. Sea Grant Technical Bulletin 7, Univ. of Miami. $175 \mathrm{pp}$.

Parker, G.G. and C.W. Cooke. 1944. Late Cenozoic geology of southern Florida with a discussion of the ground water. Florida Geol. Survey. Geol. Bull. Vol. 27. 119 pp.

Pennak, R.W. 1953. Freshwater Invertebrates of the United States. The Ronald Press Co. New York. 769 pp.

Perry, L.M. and J.S. Schwengel. 1955. Marine Shells of the Western Coast of Florida. Paeleontological Res. Inst. Ithaca, New York. $87 \mathrm{pp}$.

Poirrier, M.A. and M.M. Mulino. 1977. The impact of the 1975 Bonnet Carre Spillway opening on epifaunal invertebrates in southern Lake pontchartrain. Jour. Elish. Mitch. Sci. Soc. 93 (1):11-18.

Pool, D.J., A.E. Lugo and S.C. Snedaker. 1974. Litter production in mangrove forests of southern Florida and Puerto Rico. In: Proceedings of International Symposium on Biology and Management of Mangroves. Honolulu. Vol. I. pp. 213-237.

Rabl, A. and C.E. Nielson. 1975. Solar ponds for space heating. Solar Energy Vol. 17:1-12.

Rand, M.C., A.E. Greenberg, and M.J. Taras. 1976a. Standard methods for the examination of water and wastewater. I4th edition. M.C. Rand, A.E. Greenberg and M.J. Taras, editors. American Public Health Assoc. Washington, D.C. 1193 pp. 
Remaine, A. and C. Schlieper. 1971. Biology of Brackish Water. Wiley Interscience. New York. $372 \mathrm{pp}$.

Reynolds, Smith and Hills. 1979. Big Cypress Basin excavation study. Basin Program No. 2502. Reynolds, Smith and Hills Environmental Science and Engineering, Inc. Report submitted to: Big Cypress Basin Board, South Florida Water Management District. Jan. 1977. pp 1-1 to $6-23$.

Riley, J.P. and R. Chester. 1971. Introduction to marine chemistry. Academic Press. New York. 465 pp.

Ritchie, J.C., J.R. McHenry, and F.R. Schiebe. 1978. The vertical distribution of suspended sediments in resevoirs. Journ. Water Pol. Cont. Fed. April, 1978. pp 734738 .

Ruane, R.J. and P.A. Krenkel. 1978. Nitrification and other factors affecting nitrogen in the Holston River. Journ. Water Pol. Cont. Fed. August, 1978. pp 2016-2028.

Schneider, D.I. 1973. The limnology of a meromictic, sinkhole lake in south Florida. Ph.D. Dissertation, Univ. of Miami, Coral Gables, Fla. $146 \mathrm{pp}$.

Shannon, C.E. and E. Weaver. 1949. The mathematical theory of communications. Univ. of Illinois Press. Unbana.117 pp.

Smart, R.M. and J.W. Barko. 1978. Influence of sediment, salinity, and nutrients on the physiological ecology of selected salt marsh plants. Est. and Coastal Mar. Sci. $7(5): 487-495$.

Smith, K.L. Jr., G.T. Rowe and J.A. Nichols. 1972. Benthic community respiration near the woods Hole sewage outfall. Est. and Coastal Mar. Sci. I(1):65-70.

Sorenson, T. 1949. A method of establishing groups of equal amplitude in plant society, based on similarity of species content. K. Danske Vidensk, Selsk. Vol. 5:1-34.

sorokin, J.I. 1965. On the trophic role of chemosynthesis and bacterial biosynthesis in water bodies. Mem. Inst. Ital. Idrobiol. Suppl. Vol. 18:187-205.

Sorokin, J.I. and N. Donato. 1975. On the carbon and sulphur metabolism in the meromictic Lake Faro (Sicily) Hydrobiologia $42(2): 241-252$. 
Strickland, J.D.H. and T.R. Parsons. 1972. A practical handbook of seawater analysis. Fisheries Research Board of Canada. Bull. 167 (2nd edition) Ottawa. $310 \mathrm{pp}$.

Subrahmanyar, C.B., W.L. Kruczynski, and S.H. Drake. 1976. Studies on the animal communities in two North Florida salt marshes. Part II. Macroinvertebrate Communities. Bull. Mar. Sci. 26(2):172-195.

Sverdrup, H.V., M.W. Johnson and R.H. Fleming. 1942. The Oceans. Prentice-Hall, New York. 1087 pp.

Tabb, D.C., E.J. Heald and G.L. Beardsley. 1977. Natural resource assessment of Marco Mainland properties tract. Phase I. Draft-report to the Deltona Corp. $48 \mathrm{pp}$.

Taylor, W.G. III. 1960. A preliminary limnological investigation of Round Lake in New York. M.S. Thesis, College of Forestry, Syracuse Univ. New York. 135 pp.

Taylor, J.L., J.R. Hall and C.H. Saloman. 1970. Mollusks and benthic environments in Hillsborough Bay, Florida. Fish. Bull. 68(2):191-202.

Taylor, J.I., and C.H. Saloman. 1968. Some effects of hydraulic dredging and coastal development in Boca Ciega Bay, Florida. Fish. Bull. 67(2):213-238.

Turner, R.E. 1978. Community plankton respiration in a salt marsh estuary and the importance of macrophytic leachates. Limnology and Oceanography. 23(3):442-451.

USEPA. 1974. Methods for chemical analysis of water and wastes, 1974. USEPA Environmental monitoring and support laboratory. Cincinnati, Ohio. pp 1-297.

1975a. Chemical analysis for water pollutants. Training manual. USEPA. Office of Water Program Operations. Cincinnati, Ohio. pp. I-I to 24-I.

1976b. Quality criteria for water. USEPA Office of Water and Hazardous Materials. Washington, D.C. $256 \mathrm{pp}$.

Valiela, J., J.M. Teal, S. Volkmann, D. Shafer and E.J. Carpenter. 1978. Nutrient and particulate fluxes in a salt marsh ecosystem. Tidal exchanges and inputs by precipitation and groundwater. Limnology and Oceanography. $23(4): 798-812$.

Vollenweider, R.A. 1974. A manual on methods for measuring primary production in aquatic environments. IBP Handbook No. 12. (2nd edition) Oxford. $225 \mathrm{pp}$. 
Weinstein, M.P., C.M. Courtney, and J.C. Kinch. 1977. The Marco Island estuary: A summary of physicochemical and biological parameters. Fla. Sci. 40(2):97-124.

Wurd, D.M. and T.D. Brock. 1978. Hydrocarbon biodegradation in hypersaline environments. Applied and Env. Microbiol. $35(2): 353-359$.

Zangrando, F. and H.C. Bryant. 1978. A salt gradient solar pond. Solar Age. April, 1978. pp. 21-36. 